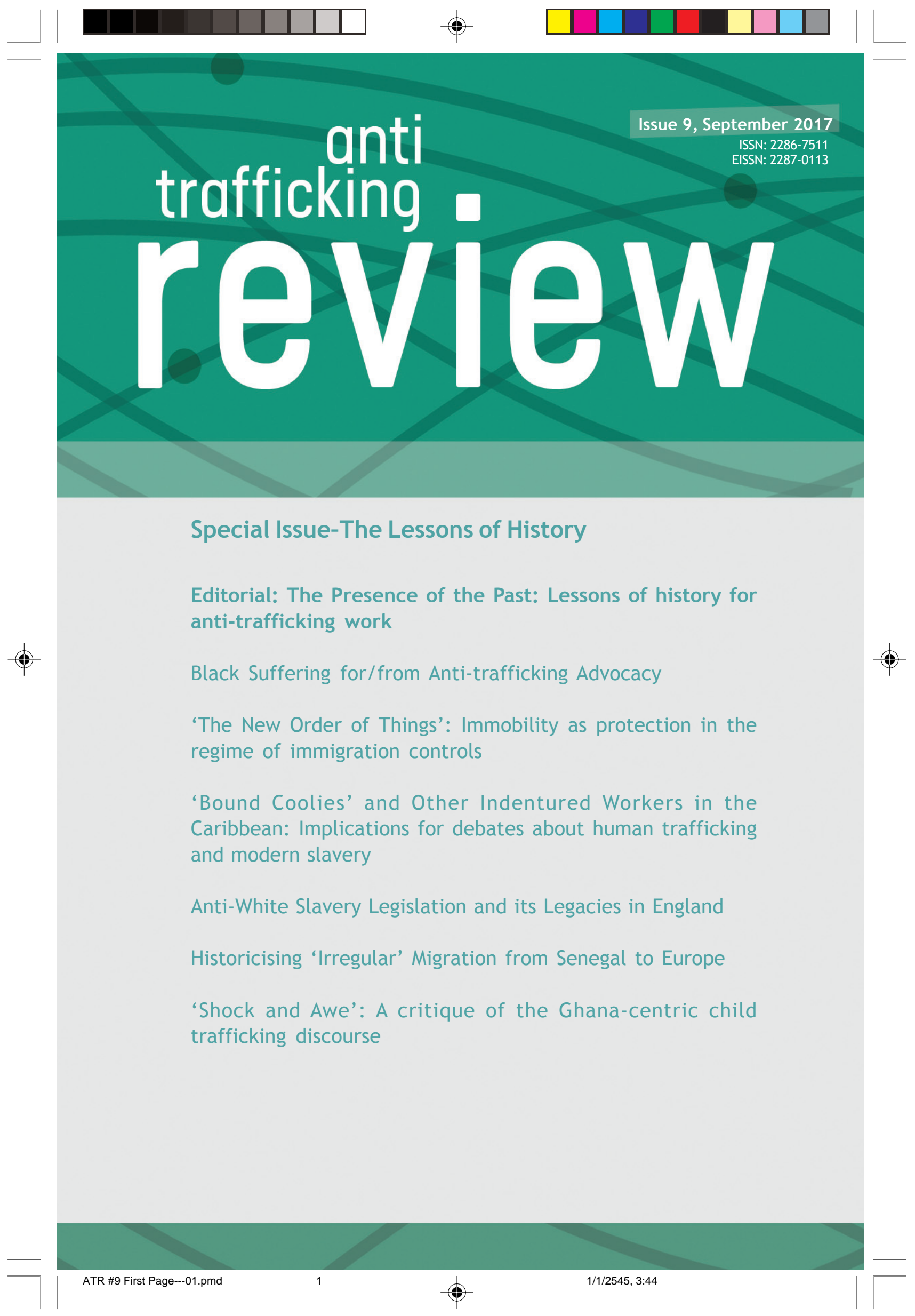



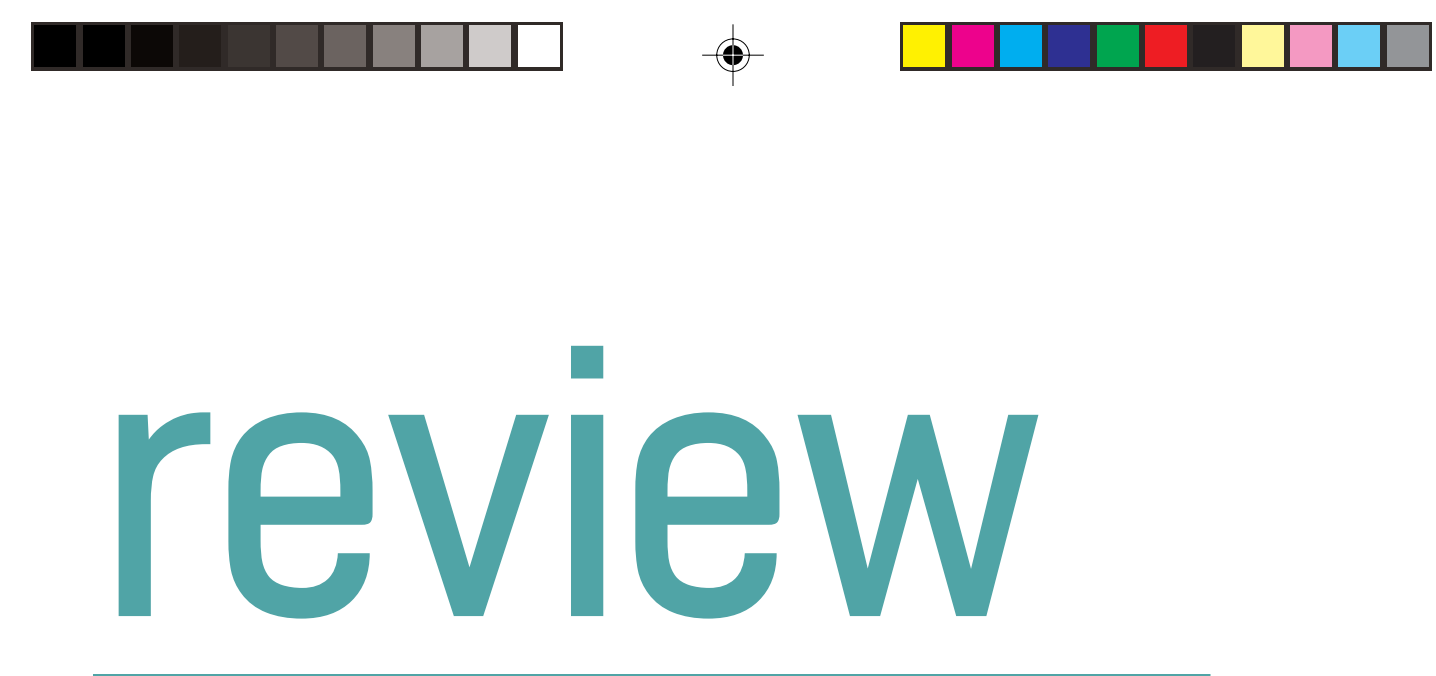

\section{GUEST EDITOR}

JULIA O'CONNELL DAVIDSON

EDITOR

\section{BORISLAV GERASIMOV}

\section{EDITORIAL BOARD}

RUTVICA ANDRIJASEVIC, University of Bristol, United Kingdom

JACQUELINE BHABHA, Harvard School of Public Health, United States

URMILA BHOOLA, UN Special Rapporteur on contemporary forms

of slavery, including its causes and consequences, South Africa

XIANG BIAO, Oxford University, United Kingdom

LUCIANA CAMPELLO, Panamerican Health Organization, Brazil

MIKE DOTTRIDGE, Independent Human Rights Consultant, United Kingdom

JOY NGOZI EZEILO, University of Nigeria; Former UN Special Rapporteur on

trafficking in persons, especially women and children, Nigeria

ANNE GALLAGHER, Independent scholar and legal advisor, Australia

JOHN GEE, Transient Workers Count Too, Singapore

CHANDRE GOULD, Institute for Security Studies, South Africa

SUZANNE HOFF, La Strada International, The Netherlands

KRISTIINA KANGASPUNTA, United Nations Office on Drugs and Crime, Austria

KAMALA KEMPADOO, York University, Canada

ANNALEE LEPP, University of Victoria, Canada

MARIKA WEN MCADAM, Independent Consultant, Australia

SVERRE MOLLAND, The Australian National University, Australia

REBECCA NAPIER-MOORE, Independent Consultant, Thailand

MARINA NOVAES, Secretariat of Human Rights and Citizenship

of Sao Paulo s City Hall, Brazil

VICTORIA IJEOMA NWOGU, United Nations Development Programme, Somalia

JULIA O'CONNELL DAVIDSON, University of Bristol, United Kingdom

PIA OBEROI, Office of the High Commissioner for Human Rights, Switzerland

SAM OKYERE, University of Nottingham, United Kingdom

ELAINE PEARSON, Human Rights Watch, Australia

NICOLA PIPER, University of Sydney, Australia

NIVEDITA PRASAD, Alice Salomon University of Applied Sciences, Germany

CAROLINE ROBINSON, Focus on Labour Exploitation, United Kingdom

JYOTI SANGHERA, Office of the High Commissioner for Human Rights, Switzerland

MARIE SEGRAVE, Monash University, Australia

ELENA SHIH, Brown University, United States

KENDRA STRAUSS, Simon Fraser University, United States

REBECCA SURTEES, NEXUS Institute, United States

SALLIE YEA, Independent scholar and consultant, Australia

CATHY ZIMMERMAN, London School of Hygiene and Tropical Medicine, United Kingdom 


\section{ANTI-TRAFFICKING REVIEW}

\section{Special Issue}

\section{THE LESSONS OF HISTORY}

Issue 9 September 2017

The Anti-Trafficking Review (ISSN 2286-7511) is published by the Global Alliance Against Traffic in Women (GAATW), a network of over 80 NGOs worldwide focused on advancing the human rights of migrants and trafficked persons.

The Anti-Trafficking Review promotes a human rights-based approach to anti-trafficking. It explores trafficking in its broader context including gender analyses and intersections with labour and migration. It offers an outlet and space for dialogue between academics, practitioners, trafficked persons and advocates seeking to communicate new ideas and findings to those working for and with trafficked persons.

The Review is primarily an e-journal, published biannually. The journal presents rigorously considered, peer-reviewed material in clear English. Each issue relates to an emerging or overlooked theme in the field of anti-trafficking.

Articles contained in the Review represent the views of the respective authors and not necessarily those of the editors, the Editorial Board, the GAATW network or its members. The editorial team reserves the right to edit all articles before publication. 
The Anti-Trafficking Review is an open access publication distributed under the terms of the Creative Commons Attribution License (CC-BY).

The Anti-Trafficking Review promotes the sharing of information, and we therefore encourage the reproduction and onward dissemination of articles published with us. 


\section{ANTI-TRAFFICKING REVIEW}

Issue 9, September 2017

1 Editorial: The Presence of the Past: Lessons of history for anti-trafficking work Julia O'Connell Davidson

Thematic Articles: The Lessons of History

14 Black Suffering for/from Anti-trafficking Advocacy

Lyndsey P. Beutin

31 'The New Order of Things': Immobility as protection in the regime of immigration controls

Nandita Sharma

48 'Bound Coolies' and Other Indentured Workers in the Caribbean: Implications for debates about human trafficking and modern slavery

Kamala Kempadoo

64 Anti-White Slavery Legislation and its Legacies in England Laura Lammasniemi

77 Historicising 'Irregular' Migration from Senegal to Europe Stephanie Maher

92 'Shock and Awe': A critique of the Ghanacentric child trafficking discourse

Samuel Okyere 


\title{
Editorial: The Presence of the Past: Lessons of history for anti-trafficking work
}

\author{
Julia O'Connell Davidson
}

Please cite this article as: J O'Connell Davidson, 'Editorial: The Presence of the Past: Lessons of history for anti-trafficking work', Anti-Trafficking Review, issue 9, 2017, pp. 1-12, www.antitraffickingreview.org

This issue of the Anti-Trafficking Review is concerned with some of the histories that created, and that continue to shape, both the present-day phenomena discussed under the rubric of trafficking, and the contemporary discourse of trafficking itself. One such history is that of transatlantic slavery. Since the millennium, numerous NGOs have been founded in the US, Australia and Europe with a mission to end what they call 'modern slavery'. Their campaigns have overlapped with, and played a significant role in shaping, the development of media, NGO, policy and political discourse on human trafficking, which is, according to the antislavery NGO Free the Slaves, 'the modern day slave tradethe process of enslaving a person'. ${ }^{1}$ In this discourse, the history of transatlantic slavery is invoked by means of visual as well as textual references in order to emphasise the severity of trafficking (and other phenomena included under the umbrella of 'modern slavery') as a human rights violation. The message has been communicated so effectively that although in international law slavery is held to be only one of several possible outcomes of trafficking, in the antitrafficking rhetoric emanating from national and international policy agencies, as well as NGOs, trafficking is now frequently said to be 'modern slavery'.

1 Free The Slaves, 'About Slavery: Frequently Asked Questions', Free the Slaves, https://www.freetheslaves.net/faq.

2 BBC, 'UN Forum Aims to End Trafficking', BBC News, 21 February 2008, http:/ / newsvote.bbc.co.uk/2/hi/europe/7242180.stm; UNODC, 'Transnational Organized Crime: Let's put them out of business', UNODC, 2015, https://www.unodc.org/ toc/en/crimes/human-trafficking.html; T May, 'Theresa May: The abhorrent evil of human trafficking taking place on London's streets', Metro Blogs, 14 October 2013, retrieved 10 January 2015, http://metro.co.uk/2013/10/14/theresa-may-the-evilof-modern-day-slavery-taking-place-on-londons-streets-4144671/.

This is an open-access article distributed under the terms of the Creative Commons Attribution License (CC-BY). Under the CC-BY license, the public is free to share, adapt, and make commercial use of the work. Users must always give proper attribution to the authors and the Anti-Trafficking Review. 
The primary lesson contemporary antislavery actors draw from the history they reference concerns the importance of antislavery activism. Today, as in the past, they say, activists can play a central role in educating the public about the horror of slavery, mobilising communities against it, and pressing states to take action to end it. They devote very little attention to the historical details of Atlantic World slavery. Indeed, though it makes for powerful rhetoric, the discourse of 'trafficking as modern slavery' displays a fairly spectacular disregard for historical reality. The large-scale, profitable, and legally sanctioned business of shipping human beings from Africa into chattel slavery in the New World that flourished between the fifteenth and nineteenth centuries relied on overwhelming physical force at every stage - from the moment of kidnap, through the journey to the West African coast, detention in the dungeons of fortresses and castles prior to shipment, during the Middle Passage itself, and on arrival. ${ }^{3}$ It is true that in the contemporary world, some cases have been documented in which people have been snatched from home or street, forcibly moved across borders or to other regions of their home country, then brutally exploited. But if the term 'human trafficking' was applied only to such cases, it would be a numerically small phenomenon, far removed from the estimates of hundreds of thousands or even millions that are routinely touted by state and non-state actors involved in anti-trafficking work. The vast bulk of what is described as trafficking involves individuals who actively wanted to move and/or sought job opportunities in another region or country or at sea. And unlike the Africans who were transported into chattel slavery, they typically had compelling reasons for wishing to migrate, so much so that many were willing to take on heavy debts in order to achieve that end.

At the point of departure, the story of trafficking and that of the transatlantic slave trade could not be more different, and the situation faced on arrival is also unlike that of the Atlantic World chattel slavery in many important respects. Today's antislavery activists characterise slavery as 'a relationship between (at least) two people' that is involuntary, and entails labour exploitation and violence or its threat. ${ }^{4}$ But Atlantic World slavery was much more than simply a relationship between individuals. 'Slave' was a status ascribed by the state. It conferred on the enslaved a double character as both 'things' (property) and 'persons' criminally responsible in law for any effort to escape or resist their owners. It was because Africans and their descendants in the Atlantic World were given this double character in law that people who were ascribed free status could hold property rights in them (i.e., treat them as fungible commodities) whilst simultaneously controlling and exacting labour from them as household dependents. Slavery designated 'a relation to law, state, and sovereign power; a condition of disfigured personhood, civil incapacitation, and bare life', as Stephen Best and Saidiya Hartman put it. ${ }^{5}$

3 S Hartman, Lose Your Mother: A journey along the Atlantic slave route, Farrar, Straus and Giroux, New York, 2007.

4 K Bales, 'Testing a Theory of Modern Slavery', Free the Slaves, 2006.

5 S Best and S Hartman, 'Fugitive Justice', Representations, vol. 92, issue 1, 2005, pp. $1-15$, p. 10. 
Asking questions about who today stands in similar relation to law, state, and sovereign power might teach us a great deal about relations of exploitation and heavy, often violent, restraints on freedom in the contemporary world. Such questions are, however, absent in dominant discourse on 'modern slavery', which focuses on the powers exercised by individual 'modern slaveholders' over individual 'modern slaves', not the structural conditions that produce the asymmetry of power between them. And it is precisely because this discourse works with such a hollow description of transatlantic slavery that it has such wide, politically crosscutting appeal. Almost everyone can agree that it is wrong for one individual to kidnap or falsely imprison another, starve, rape and beat her or him, and/or use violence or its threat to force them to labour for little or no pay and prevent them from escaping. But there is no consensus regarding what should be done about the legal, political, social and economic machinery that makes some groups, not others, vulnerable to these forms of violent exploitation. Nor is there consensus on the kinds of freedoms that should be universally enjoyed by those who are rescued from such situations. And therein lies another feature of the history of Atlantic World slavery that goes unremarked by today's antislavery campaigners.

In the eighteenth century, many white Europeans and Americans decried the cruelties of slavery and the vicious or licentious actions of individual slaveholders, but did not move from there to argue for slavery's abolition, only its amelioration. Meanwhile, those who, from the late eighteenth century, did argue for abolition did not share a vision of the forms of economic and social relationships that should replace it, or of the freedoms that should be enjoyed by emancipated slaves. Not all abolitionists considered the coercive and servile relationship between slave and master as a fundamental wrong of slavery, for example. Industrial wage workers of the same period also had Masters to whom they were often bound, to varying degrees, by highly coercive legal as well as pecuniary pressures, ${ }^{6}$ and in Britain, many of the antislavery movement's key figures were themselves employers with strong views on the need for servants to be industrious, diligent, sober, faithful, and respectful to their Masters. As David Bryon Davis points out, 'A denunciation of colonial slavery... implied no taste for a freer or more equal society. ${ }^{7}$ This was true in relation to racial as well as class inequalities. Only some antislavery activists struggled for racial equality as well as an end to slavery. William Wilberforce, memorialised as a saintly figure by contemporary antislavery activists, had reservations about the capacity of enslaved Africans and their descendants to exercise freedom so great that his primary concern was to end the transatlantic slave trade, rather than slavery per se. '[O]ur object,' he explained, 'was by ameliorating regulations, and by stopping the

6 R Steinfeld, Coercion, Contract and Free Labor in the Nineteenth Century, Cambridge University Press, Cambridge, 2001.

7 D Davis, 'The Problem of Slavery in the Age of Revolution, 1770-1823' in T Bender (ed.), The Antislavery Debate, University of California Press, Berkeley, 1992. 
influx of uninstructed savages, to advance slowly towards the period when these unhappy things might exchange their degraded state of slavery for that of free and industrious peasantry."

White British and American antislavery thinkers were not all keen to have the slaves they sought to liberate live alongside them as equal members of their society. Abraham Lincoln, for instance, originally favoured a policy of deporting emancipated slaves, either to Haiti or to colonies in Africa: 'it would be better to export them all to some fertile country with a good climate, which they could have to themselves'. ' Even Granville Sharp, one of the more radical figures of the British antislavery movement, expressed concerns about 'swarms of negroes' arriving in England, ${ }^{10}$ and is reputed to have actively sought to discourage English gentlemen from offering support to destitute black people in London on grounds that 'charity would blind them to their own best interest' and discourage them from agreeing to embark for Sierra Leone, a British colony founded for the purpose of receiving Africans 'rescued' from illegal slave ships. ${ }^{11}$

Many aspects of such debate on the fate of emancipated slaves resonate with contemporary debates on trafficking and the rights that should and should not be extended to those redeemed from 'modern slavery'. But these are not the echoes of the past that capture the attention of today's antislavery campaigners, presumably because they do not sit well with the broader, celebratory story about liberal modernity that underpins contemporary abolitionist thinking. That narrative glosses over the fact that Atlantic World slavery was modern slavery (it emerged and flourished alongside liberalism into the period generally thought of as well and truly modern) ${ }^{12}$ focusing only on the fact that modern liberal states abolished slavery in the nineteenth century. It sees only liberalism's emancipatory aspect, forgetting the central paradox of its history, namely the fact that liberal ideology can be and has been marshalled in support of the violent subjugation of truly immense numbers of people. ${ }^{13}$ This partial and selective approach to history matters for the present. Three examples of the dangers it presents that are particularly important to this special issue are briefly noted below.

8 Quoted in M Jordan, The Great Abolition Sham, Sutton Publishing, Stroud, 2005, p.181.

9 C H Wesley, 'Lincoln's Plans for Colonizing the Emancipated Negroes', The Journal of Negro History, vol. 4, no. 1, 1919, pp. 7-21, p. 20.

10 R Blackburn, The American Crucible: Slavery, emancipation and buman rights, Verso, London, 2011, p. 151.

11 Davis, p. 100.

12 C Mills, The Racial Contract, Cornell University Press, Ithaca, 1998.

13 D Losurdo, Liberalism: A counter-history, Verso, London, 2011, p. 243. 


\section{The Dangers of Selective Memory}

The first risk that attaches to the selective recall of transatlantic slavery in antitrafficking discourse concerns race. The idea of race as constitutive of borders between flesh and blood human beings in terms of their capacities, moral worth and rights is inextricably bound to the history of Atlantic World slavery. In the course of that history, the freedom/slavery binary of liberal thought came to map onto an imagined racial binary between white and black (and non-white more generally), such that citizenship, which implied enjoyment of the 'rights of Man', was coded as white, and therefore impossible for those racialised as black, whether or not they were enslaved. ${ }^{14}$ The abolition of slavery did not mark the end of race as a system of domination. It persisted, and it continues to privilege white and devastate black lives in the contemporary world. The discourse of 'trafficking as modern slavery' actively deflects attention from this. It works to minimise the scale and nature of the atrocity of transatlantic racial slavery ${ }^{15}$ (epitomised by the oft-repeated claim that 'there are more slaves today than at any point in human history'), ${ }^{16}$ and to dissociate it from the specifically anti-black racism it fostered. It thus produces a lens that occludes the relationship between white privilege and the on-going devaluation and endangerment of black lives in the US, Brazil and other former slave and colonial states. ${ }^{17}$

A second risk arising from simplistic analogies between wrongs past and present is that they hamper, rather than facilitate, efforts to secure rights and protections in the contemporary moment. Take trafficking, for example. The definition provided in the UN Trafficking Protocol allows that the process of trafficking can lead to a number of possible outcomes, of which, as already noted, slavery is only one. The (very minimal) obligations to persons recognised as victims of trafficking that many states have committed themselves to and built into domestic 'trafficking'

14 A Cesaire, Discourse on Colonialism, Monthly Review Press, New York, 1972.

15 K Bravo, 'The Role of the Transatlantic Slave Trade in Contemporary Anti-Human Trafficking Discourse', Seattle Journal for Social Justice, vol. 9, no. 2, 2011, pp. 555597.

16 T McNally, 'There are More Slaves Today than at Any Time in Human History', Alternet, 24 August 2009, retrieved 10 September 2016, http://www.alternet.org/ story/142171/there_are_more_slaves_today_than_at_any_time_in_human_ history/.

17 T Woods, 'Surrogate Selves: Notes on anti-trafficking and anti-blackness', Social Identities, vol. 19, no. 1, 2013, pp. 120-134; J Alves, 'Police Terror in Brazil', openDemocracy, 15 October 2015, https://www.opendemocracy.net/jaime-alves/ police-terror-in-brazil; A Davis, 'From Michael Brown to Assata Shakur, the Racist State of America Persists', The Guardian, 1 November 2014, retrieved 20 August 2017, http://www.theguardian.com/commentisfree/2014/nov/01/michael-brownassata-shakur-racist-state-of-america. 
legislation should thus, in theory, be extended to individuals who have been moved (by means of deception, coercion, etc.) for purposes of exploitation, whether or not they experience conditions that might be legally understood as 'slavery'. However, in the early 2000s, the focus in most countries was almost exclusively on women and girls in prostitution, and very often to stand any chance of being identified and assisted as a victim of trafficking by the authorities, a migrant woman or girl working in the sex trade needed to demonstrate first that she did not choose or consent to work in prostitution, and second that she had been subject to immense violence. ${ }^{18}$ 'Trafficked women' were, as Claudia Aradau put it, 'dis-identified from categories of migrants, criminals or prostitutes by the emphasis on raw physical suffering., ${ }^{19}$

Over the past decade, there has been a shift in policy discourse on trafficking, with increasing emphasis on what is termed 'labour trafficking' as well as what was dubbed 'sex trafficking'. The extension of the term 'trafficking' to non-sexual and non-criminalised forms of labour, whilst logical given the UN Trafficking Protocol definition, potentially transforms it into an even hotter political potato. For where it is often (and wrongly) assumed that no woman voluntarily elects to work in prostitution, it is widely acknowledged that people can and do choose to migrate to work in other sectors, such as agriculture, construction, and domestic work. It is also widely known that migrant workers in what are described as '3D' jobs (difficult, dangerous, and dirty) often labour under poor conditions for low wages, are frequently overcharged for cramped and dilapidated accommodation, commonly have to indebt themselves to cover recruitment, visa and transportation fees, and are not always fully apprised of the terms and conditions under which they will

18 R Andrijasevic, Migration, Agency and Citizenship in Sex Trafficking, Palgrave Macmillan, Houndmills, 2010; E Bernstein, 'Militarized Humanitarianism Meets Carceral Feminism: The politics of sex, rights, and freedom in contemporary anti-trafficking campaigns', Signs, vol. 36, no. 1, 2010, pp. 45-72; W Chapkis, 'Soft Glove, Punishing Fist: The Trafficking Victims Protection Act of 2000' in E Bernstein and L Schaffner (eds.), Regulating Sex, Routledge, London, 2005; J Doezema, 'Loose Women or Lost Women? The re-emergence of the myth of "white slavery" in contemporary discourses of trafficking in women', Gender Issues, vol. 18, no. 1, 1999, pp. 23-50; J O’Connell Davidson, 'Will the Real Sex Slave Please Stand up?', Feminist Review, vol. 83, issue 1, 2006, pp. 4-22.

19 C Aradau, 'The Perverse Politics of Four-Letter Words: Risk and pity in the securitisation of human trafficking', Millennium: Journal of International Studies, vol. 33, no. 2, 2004, p. 257. 
work. ${ }^{20}$ Depending on how 'exploitation' is defined, and on the type and degree of deception about arrangements at the point of destination that is considered to nullify consent, the problem of 'labour trafficking' could be accurately described as limited, albeit serious, or vast and virtually endemic to temporary migrant labour schemes around the world.

Again the emphasis on raw physical suffering found in 'modern slavery' discourse helps to rein the term 'trafficking' back onto territory where politicians who have no interest in defending or extending the rights of either migrants or workers are more comfortable. Migrant workers who are exploited and deceived, but have not been bodily shackled, or locked into their squalid accommodation, or raped or beaten or threatened with death, can be ignored in the design and implementation of anti-trafficking policy. 'Trafficking as modern slavery' talk also works on the imagination of frontline actors involved in victim identification, protection and support, and the prosecution of trafficking cases, shaping and restricting understandings of who can be a victim, and who a perpetrator. In the US, Janie Chuang observes that 'strategic use of slavery imagery by defense counsel in trafficking prosecutions can raise jurors' expectations of more extreme harms than anti-trafficking norms actually require. That not only undermines prosecutorial efforts, but it renders accountability and redress for victims even more elusive than they already are. ${ }^{21}$

Likewise, Brenna Bhandar notes that efforts to legally challenge workfare schemes in the UK as forced or compulsory labour under Article 4 of the European Convention on Human Rights ${ }^{22}$ have failed, in large part because they cannot be demonstrated to be equivalent to slavery, indentured labour, or other forced labour systems employed in colonial settings. And yet:

20 See, for example: B Anderson, Us and Them: The dangerous politics of immigration control, Oxford University Press, Oxford, 2013; G Standing, The Precariat: The new dangerous class, Bloomsbury Academic, London, 2011; R Surtees, 'At Sea: The trafficking of seafarers and fishers from Ukraine' in M Dragiewicz (ed.) Global Human Trafficking, Routledge, London, 2015; B Wu, G Lan and J Sheehan, Employment Conditions of Chinese Migrant Workers in the East Midlands, International Labour Organization, 2010.

21 J Chuang, "The Challenges and Perils of Reframing Trafficking as "Modern-Day Slavery"”, Anti-Trafficking Revien, issue 5, 2015, pp. 146-149.

22 Article 4 prohibits slavery and forced labour. 
how curious it is to import into contemporary human rights jurisprudence colonial slavery as the standard against which any claims to forced or compulsory labour are measured. Engaging in what one might call a peculiar sort of relativism, it becomes impossible to imagine conditions under which a claimant might be successful in an Article 4 claim against the State. ${ }^{23}$

A third danger of the false analogy between trafficking today and slavery historically is that it encourages measures not to promote safer migration but to prevent certain forms of movement per se, including children's independent migration. In fact, so far as undocumented migration is concerned, the analogy has been used to justify the very costly and extraordinarily violent, often lethal, controls states have set in place in an attempt to immobilise the people whose presence on their territory is deemed undesirable. ${ }^{24}$ In political and media discourse on the growing death toll amongst migrants seeking to make the Mediterranean sea crossing from Libya to Italy in the spring of 2015, for example, responsibility was repeatedly laid at the feet of 'people traffickers'. Italian Prime Minister Matteo Renzi wrote that 'human traffickers are the slave traders of the 21 st century, and they should be brought to justice', ${ }^{25}$ and EU leaders vowed to use their military might to 'identify, seize/capture, and destroy' the vessels used in this modern-day slave trade. ${ }^{26}$ In commentary on the current so-called 'migration crisis', journalists as well as politicians continue to use the term 'trafficking' interchangeably with 'smuggling' as a catch-all term for the facilitation of movement across borders without state sanction, and trafficking continues to be described as the modern equivalent of the transatlantic slave trade. Represented as such, any and all means employed by the state to suppress unauthorised movement appear morally justifiable. Even

23 B Bhandar, 'Property, Law, and Race: Modes of abstraction', UC Irvine Law Review, vol. 4, 2014, p. 211.

24 R Andersson, Illegality, Inc., University of California Press, Oakland, 2014; T Baird, 'The Business of Militarized Borders in the European Union', War Resisters International, 1 September 2015, https://www.wri-irg.org/node/24759; Border Crossing Observatory, Australian Border Deaths Database, retrieved 9 March 2015, http://artsonline.monash.edu.au/thebordercrossingobservatory/publications/ australian-border-deaths-database/; International Organization for Migration, Fatal Journeys: Tracking lives lost during migration, IOM, Geneva, 2014, retrieved 2 March 2015, http://publications.iom.int/bookstore/free/FatalJourneys_Countingthe Uncounted.pdf.

25 M Renzi, 'Helping the migrants is everyone's duty', New York Times, 23 April 2015, http://www.nytimes.com/2015/04/23/opinion/matteo-renzi-helping-themigrants-is-everyones-duty.html?_r $=1$.

26 I Traynor, 'Migrant Crisis: EU plan to strike Libya networks could include ground forces', The Guardian, 13 May 2015, http://www.theguardian.com/world/2015/ may/13/migrant-crisis-eu-plan-to-strike-libya-networks-could-include-groundforces. 
those who illegally facilitate the mobility of people who desperately want to move, including those fleeing war, persecution, and other threats to life itself, become legitimate targets of state violence. And even far-right groups mobilising against black and Muslim presence in Europe by disrupting humanitarian efforts to save lives in the Mediterranean can claim to be acting with the noble aim of protecting migrants from trafficking - the contemporary slave trade. ${ }^{27}$

Sociologist W. E. B. Du Bois remarked that history is indispensable to the task of making sense of contemporary experience, observing that 'the past is the present; that without what was, nothing is' ${ }^{28}$ But as he also noted, different stories can be told about history, and the histories we choose to tell (and to hear) can produce very different understandings of the present. This special issue critically examines the use and abuse of the history of transatlantic slavery in anti-trafficking discourse. Its contributors explore the dangerous political consequences of the frequent repetition of the false analogy between the transatlantic slave trade and trafficking, and offer insights into other histories that may have more useful lessons for those engaged in anti-trafficking work today.

\section{This Special Issue}

The first contribution to this special issue illuminates the race politics that lie beneath 'modern slavery' discourse through a critical interrogation of the highly selective forms of remembering and forgetting it sets in play. Lyndsey Beutin begins by analysing the images used in a project dedicated to making the history of the original abolitionist movement 'usable' for the contemporary antislavery project, showing how it appropriates black suffering to animate its own antitrafficking narrative, yet fails to either acknowledge or endorse the on-going black liberation struggle. The current trend of incorporating anti-trafficking exhibitions into institutions that preserve the history of slavery and abolition also serves to conceal the racial logics that underpinned transatlantic slavery and survived its abolition to produce anti-blackness and white privilege in the present, Beutin argues. In addition to sidelining the heavy restraints on freedom that race as a system of domination still implies for those racialised as black in Europe and the Americas, 'the structural exclusions that colonialism and the transatlantic slave trade forced upon the global South' are obscured, even though the latter actually form the context in which people become vulnerable to the forms of abuse and exploitation discussed under the heading 'trafficking'.

27 R Lewis, 'Stranded Anti-immigrant Ship Gets Help from Refugee Rescue Boat', Time, 11 August 2017.

${ }^{28}$ W E B Du Bois quoted in B Quarles, Black Mosaic, University of Massachusetts Press, Amherst, 1988, p. 88. 
Contributions from Nandita Sharma and Kamala Kempadoo delve deeper into the history of those structural exclusions. Sharma's focus is on human mobility, and her starting point is the problem it represented for economic and political elites seeking a controllable supply of labour in a post-slavery world. Through a detailed consideration of the legal regulation of the system of indentured, contract labour that replaced slave labour in British colonies in the nineteenth century, she shows how the figure of 'the immigrant' came into being as the person whose movement across space was to be regulated, initially by the British imperial state and later by nationalising states, in order to assure a continuing supply of cheap and malleable labour in a world without slavery. Paradoxically, however, the regulations that severely constrained this new workforce were legitimated as a form of protection against slavery, and Sharma finds powerful echoes of this in contemporary 'trafficking as modern slavery' discourse. The most serious threats to migrating people today come from the immigration systems operated by nation states, she argues, and yet far from demanding an end to states' use of overwhelming physical force against ordinary, peaceful migrating people, that discourse operates to legitimate nationalised states' enactment of drastic and often deadly constraints on their mobility.

In standard liberal accounts of historical development (and even in some Marxist accounts), it is assumed that modernity initiated the incremental growth of freedom as serfs, slaves, and servants gradually threw off the shackles that bound them and free wage labour was established as the norm. Kempadoo's article alerts us to problems with that linear tale, and to the particular light that Caribbean scholarship can shed on questions about labour and freedom, given the many, often overlapping, forms of unfree labour historically experienced in the region. The multiple and often simultaneous histories of slavery and servitude also hold important lessons on gendered and racialised dimensions of freedom and unfreedom. Caribbean history thus provides an extremely useful lens through which to evaluate twenty-first century claims about human trafficking and 'modern slavery'. However, Kempadoo argues, more careful historical attention both to the specificities of the forms of violence, coercion and legalities that shape labour, and to working people's lives, hopes and dreams, is necessary if we are to develop the analytical tools needed to pursue and practice freedom in the contemporary world.

In her contribution, Laura Lammasniemi turns to the history of modern antitrafficking laws in England and Wales. She details a series of interrelated legal interventions enacted between 1885 and 1905 ostensibly designed to protect women and girls from so-called 'white slavery'. These interventions did not in fact provide women with protection against exploitation (either within prostitution or any other context), but because they framed 'white slavery' as a matter of criminal or immigration law, they did lead to closer controls over the lives of migrant women and of sex workers — much like present-day anti-trafficking initiatives, Lammasniemi concludes. The theme of 'protective' measures that do 
nothing to address the structures that create the need for protection but do further limit freedoms is continued in Stephanie Maher's article on 'irregular' Senegalese migration to Europe. Though today often framed as a problem of trafficking or 'modern-day slavery', there is a centuries long and culturally valued history of Senegalese migration, and it is only Europe's very recent drive to control and restrict migration that has effectively rendered such movements, and the people who undertake them, 'illegal'. The constriction of options for legal mobility has made journeys more treacherous, and more likely to generate the kind of dependencies that leave people vulnerable to exploitation. Yet once again, restrictions on mobility are presented as a humanitarian project to 'protect' the vulnerable from 'modern slavers'.

The final contribution from Samuel Okyere addresses the unintended and extremely negative consequences of 'trafficking as modern slavery' discourse for children in Ghana. Okyere outlines the long history of youth and children's independent labour migration in Ghana, and its connections to the country's wider history of colonisation, as well as to its more recent history of structural adjustment, enforced free-trade policies, land grabs, and the human insecurities all these have engendered. Again, these and other structural factors are absent from the narratives of 'child trafficking' promulgated by antislavery campaigners; narratives that whilst based on extremely dubious evidence nonetheless inform the country's precarious ranking in the US Trafficking in Persons report. Far from stimulating interventions that might better protect the rights and freedoms of Ghanaian children and youth, 'child trafficking' and 'modern slavery' discourse has become 'another mechanism of coercion and control wielded by relatively richer, powerful states' against a relatively poorer and weaker one.

Taken together, the contributions to this issue suggest that the appeal to history made by 'trafficking as modern slavery' discourse can and does work to conceal, legitimate, and sometimes even encourage, heavy restraints on human freedom, mobility and rights, including that to life itself. At the same time, they reveal that more critical engagement with the histories of transatlantic slavery and colonialism and their afterlives can teach us a great deal about the forms of violence, injustice and oppression that are today either tolerated or sanctioned in the dominant liberal world order. A focus on these lessons of history might help open up alternative political possibilities and inform different and more genuinely emancipatory approaches to anti-trafficking policy and activism. 
ANTI-TRAFFICKING REVIEW 9 (2017): 1-12

Acknowledgments

I am grateful to the Leverhulme Trust for the award of a Major Research Fellowship (MRF-2012-085), during which the arguments of this paper were developed.

Julia O'Connell Davidson is Professor of Social Research in the School of Sociology, Politics \& International Relations at the University of Bristol. She has researched and written on employment relations, sex work, sex tourism, trafficking, child migration, and debt-funded migration. Her research has also critically interrogated the concept of 'modern slavery'. She is the author of Modern Slavery: The margins of freedom (Palgrave, 2015), and Children in the Global Sex Trade (Polity, 2005), and a member of the openDemocracy Beyond Trafficking \& Slavery editorial partnership. Email: julia.oconnelldavidson@bristol.ac.uk 


\section{Thematic Articles: The Lessons of History}




\title{
Black Suffering for/from Anti-trafficking Advocacy
}

Lyndsey P. Beutin

\begin{abstract}
This article analyses the images that Antislavery Usable Past creates to promote its cause of 'making the antislavery past usable for contemporary abolition'. Drawing on collective memory studies, I discuss the political implications of how pasts are used for present issues. I argue that Antislavery Usable Past appropriates black suffering by reducing the memory and imagery of slavery to objects that are compatible with the anti-trafficking narrative, without regard for the ongoing black liberation struggle. I conclude by discussing the troubling trend of incorporating anti-trafficking exhibitions into institutions that preserve the history of slavery and abolition. Such inclusions redirect the history lessons of slavery away from understanding and addressing anti-blackness in the present and towards supporting advocacy campaigns articulated in the logics that underpinned racial chattel slavery in the first place.
\end{abstract}

Keywords: anti-blackness, appropriation, anti-trafficking, memory of slavery, museums

Please cite this article as: L P Beutin, 'Black Suffering for/from Anti-trafficking Advocacy', Anti-Trafficking Review, issue 9, 2017, pp. 14-30, www.antitraffickingreview.org

\section{Introduction}

A new UK-based humanities initiative called Antislavery Usable Past aims to make 'the antislavery past usable for contemporary abolition'. 'This multi-faceted project draws upon the images and strategies used by eighteenth- and nineteenth-century mobilisations in the UK and the US to end the transatlantic slave trade. The project endeavours to make this historical archive 'usable' — relevant and useful to changing current affairs - by making it resonate with images of contemporary examples of extreme exploitation and human trafficking throughout the world.

\footnotetext{
1 Antislavery Usable Past, website, http://www.usablepast.ac.uk/.
}

This is an open-access article distributed under the terms of the Creative Commons Attribution License (CC-BY) Under the CC-BY license, the public is free to share, adapt, and make commercial use of the work. Users must always give proper attribution to the authors and the Anti-Trafficking Review. 
The project's homepage features a prominent and startling visual comparison that appears to substantiate the power that the antislavery past holds for raising awareness about human trafficking today. The first image is the iconic eighteenth-century print of the hold of the slave ship Brooks, rendered by an artist working for British abolitionists and widely circulated as abolitionist propaganda in its time. ${ }^{2}$ The website overlays the image with the caption ' 1788 ...'. It is immediately followed by an image captioned '...2007' that pastes the historic image of the slave ship Brooks into the passenger area of a commercial airplane. The image of the airplane-slaveship comes from the organisation Anti-Slavery International and bears the slogan: 'Trafficking is Modern Slavery. The methods may have changed but people are still suffering.' Below the images, the website asserts: 'There are approximately 36 million slaves alive today: more than at any point in history.'

The juxtaposition of these images speaks to the problematic discourse of the contemporary anti-trafficking movement. In order to justify its importance, antitrafficking advocates appropriate the history of racial chattel slavery and its abolition to gain urgency, legitimacy, and moral outrage for their cause, but then minimise that same history to make trafficking today the most pressing social problem to address. Such appropriations of black suffering have important stakes for how we understand what racial chattel slavery was, the ways in which it continues to structure contemporary culture through its legacies of anti-black racism and oppression, as well as for how we understand what causes trafficking, and thus, what would be effective approaches to ending it. The Brooks print garnered outrage in the late eighteenth and early nineteenth centuries because it revealed the inhumanity of the slave trade to citizens who had the privilege of turning a blind eye. It was an abolitionist fabrication, and yet still represented an actual slaving ship and a horrific situation that black Africans were being subjected to. What does the airplane represent?

In the essay that follows, I describe how Antislavery Usable Past minimises the history of racial chattel slavery and I outline the risks such a project poses for the ongoing black liberation struggle. Drawing on collective memory studies helps us understand how and why histories are used in the present. All histories are usable-there is nothing special about antislavery history that makes it specifically useful to ending trafficking-but there are important political implications for who uses which pasts how. My analysis includes a close reading of the imagery that anchors the Antislavery Usable Past's website which reveals the ways racial chattel slavery has to be manipulated and 'made' into an object that fits into the antitrafficking discourse. In other words, simple juxtapositions of exploited bodies arranged in similar poses does little to help viewers understand the various systems

2 J Francis, 'The Brooks Slave Ship Icon: A “Universal Symbol”?', Slavery \& Abolition, vol. 30, issue 2, 2009, pp. 327-338. 
of oppression that produce such images and that continue to value different lives differently. I conclude by discussing the troubling trend of incorporating antitrafficking exhibitions into institutions that preserve the history of slavery and abolition. Such inclusions redirect the history lessons of slavery away from understanding and addressing anti-blackness in the present ${ }^{3}$ and towards supporting campaigns, however well intentioned, that are often articulated in and reproduce the racialising and capitalist logics that underpinned racial chattel slavery in the first place. My research raises concerns that the predominantly white and well financed anti-trafficking movement has invested in the wrong history lessons: using any rhetorical means available to advocate for its cause and, in so doing, reproducing the commodification of black suffering for its own gain.

\section{Collective Memory Studies}

The study of collective memory is the study of how history is deployed in the present. The field starts from the orientation that scholars must think through the meaning of representations of history in the present and take those representations as culturally significant in and of themselves, rather than languishing in debates about a present representation's fidelity to a factual past. ${ }^{4}$ Images of the past are selectively reinterpreted in the present to address a host of political and social issues including group identity formation, nationalism, state legitimacy, social cohesion, conflict resolution, historical trauma, and amelioration. ${ }^{5}$ Practices of historical and collective memory are socially useful precisely because they are partial, mutable, flexible, and endlessly adaptable to changing political circumstances and social needs. As such, groups with competing interests use and appropriate historical imagery at cross-purposes, mediated through asymmetries

3 Anti-blackness circulates globally and is a global issue even as racialisation is also shaped by local contexts. The black liberation struggle has been and continues to be a global struggle with myriad manifestations. See for instance: J Pierre, The Predicament of Blackness: Postcolonial Ghana and the politics of race, University of Chicago Press, Chicago, 2012. For the purposes of this article, my analysis of the negative implications of anti-trafficking on the black liberation struggle primarily focuses on the US context because of the hyperpresence of anti-black racism in the US, the US context of several images on the website that I analyse, and my academic training in the US.

4 J Le Goff, History and Memory, Columbia University Press, New York, 1992; M R Trouillot, Silencing the Past: Power and the production of history, Beacon Press, Boston, 1995.

5 M Halbwachs, On Collective Memory, University of Chicago Press, Chicago, 1992; P Nora, Realms of Memory (vol. 1), Columbia University Press, New York, 1997; B Zelizer, 'Reading the Past Against the Grain: The shape of memory studies', Critical Studies in Mass Communication, June 1995, pp. 214-239. 
of power. Collective memory works in unexpected ways because it is always about the social position and relation of the rememberers. ${ }^{6}$ "What memories tell us, more than anything, is the stakes held by individuals and institutions in attributing meaning to the past. ${ }^{7}$ It is not surprising, then, that history becomes appropriated for various political purposes; rather, it is crucial to understand what the appropriation does, for whom, and to what ends.

The politics of the collective memory of slavery are complex. Like other historical traumas, redeploying the history of slavery can serve many purposes. Stateproduced representations of slavery might recuperate evidence of state-sanctioned violence to tell a story of national progress and inclusion. As remembering is also related to forgetting, ${ }^{8}$ memorials to traumatic pasts can sequester the oppression in the past, making it easier to move beyond, consider finished, visit selectively or avoid completely. In contrast, counter-memories of slavery, those deployed by marginalised groups affected by the histories and legacies of slavery, might be used to explain contemporary oppression, agitate for redress for the past, or bolster a sense of group resilience and empowerment in the midst of contemporary threats to undermine it. Memories of slavery have also been 'whitewashed' by various non-state actors from dominant groups, including scholars and religious groups. For instance, many American historians, in the aftermath of the Civil War, retold the history of slavery as a benign institution. The role of white religious abolitionists in ending slavery has also been over-emphasised to shore up moral superiority in the present across former colonial empires.

Because differential social relations are produced through power, some representations of the history of slavery gain more traction, visibility, and legitimacy than others. This does not mean that counter-memories are not powerfulindeed they become even more so in the face of their erasure and co-optation. But it does mean that well-intentioned but still structurally privileged actors' representations of slavery have important political stakes. As such, those actors should interrogate carefully their own reasons for using memories of slavery and must be held accountable for the political outcomes that their uses might allow.

6 L Passerini, 'Afterword' in S Radstone and B Schwarz (eds.), Memory: Histories, theories, debates, Fordham University Press, New York, 2012, pp. 459-464.

7 M Sturken, Tangled Memories: The Vietnam War, the AIDS epidemic, and the politics of remembering, University of California Press, Berkeley, 1997, p. 9.

8 B Zelizer, Remembering to Forget: Holocaust memory through the camera's eye, University of Chicago Press, Chicago, 1998; A Huyssen, 'Monumental Seduction', New German Critique, vol. 69, 1996, pp. 181-200; A Assman, 'Canon and Archive' in A Erll and A Nunning (eds.), Cultural Memory Studies, Walter de Gruyter, New York, 2008, pp. 97-107.

9 P Connerton, How Modernity Forgets, Cambridge University Press, Cambridge, 2009; S Marschall, Landscape of Memory. Commemorative monuments, memorials and public statuary in post-apartheid South Africa, Brill, Leiden, 2010. 
As my larger research project elucidates, this includes the ways that a competing discourse of new slavery, one that is very much in line with state projects and neoliberal logic, can work to undermine other black political claims based in histories of racial chattel slavery. As I show in the next section, the history and anti-black legacies of racial chattel slavery are mortgaged for the cause of anti-trafficking, a discourse that still very much relies on and reproduces the 'white savior industrial complex'. ${ }^{10}$

\section{The Reduction of Slavery}

Critical scholars of human trafficking and anti-trafficking discourses have pointed out that using the term 'slavery' to describe human trafficking helps render the problem in an individual harm paradigm that erases the structural causes of trafficking. ${ }^{11}$ While there is no question that anti-trafficking discourse normalises the criminalisation of individuals ${ }^{12}$ — and leaves global capitalist systems intact-it is important to also note how much discursive work must be done to 'slavery' in order to make it understood as primarily about interpersonal violence. In other words, it is not just that 'slavery' helps turn human trafficking into an individual crime discursively; the memory of slavery has also been forced into an individual harm paradigm through image selectivity and circumscribed historical context. For instance, one image on Antislavery Usable Past simply features a cropped historic drawing of a single young black male subject holding his head in his hands in apparent dismay as evidence of what slavery looked like. The structural forces that underpinned and proliferated racial chattel slavery-namely racial capitalism ${ }^{13}$ and

10 T Cole, 'The White-Savior Industrial Complex', The Atlantic, 21 March 2012; J Quirk, 'Uncomfortable Silences: Anti-slavery, colonialism and imperialism', Historians Against Slavery blog, 13 February 2015.

11 J Chuang, 'Exploitation Creep and the Unmaking of Human Trafficking Law', The American Journal of International Law, vol. 108, issue 4, 2014, pp. 609-649; R Weitzer, 'Human Trafficking and Contemporary Slavery', Annual Review of Sociology, vol. 41, 2015, pp. 223-242.

12 N Sharma, 'Anti-Trafficking Rhetoric and the Making of a Global Apartheid', NWS A Journal, vol. 17, issue 3, 2005, pp. 88-111; E Bernstein, 'Militarized Humanitarianism Meets Carceral Feminism: The politics of sex, rights, and freedom in contemporary antitrafficking campaigns', Signs, vol. 36, issue 1, 2010, pp. 45-71; J Musto, Control and Protect: Collaboration, carceral protection, and domestic sex trafficking in the United States, University of California Press, Berkeley, 2016.

13 My theoretical commitments in this argument and my larger research project build upon and are indebted to scholars who have thoroughly explicated how the formations of capitalism and liberalism are fundamentally constructed through racialisation. See for instance: C J Robinson, Black Marxism: The making of the Black radical tradition, University of North Carolina Press, Chapel Hill, 1983/2000; E Williams, Capitalism and Slavery, University of North Carolina Press, Chapel Hill, 1944/1994; W E B Du 
racial liberalism ${ }^{14}$ and the myriad violences that make them possible- - are excised, undisclosed, or recovered as banal, benign, or even emancipatory systems (one anti-trafficking group promotes 'the free market to free people'). ${ }^{15}$

Anti-trafficking advocates also rely heavily on reusing imagery produced by white abolitionists as the evidence of what racial chattel slavery was, which is one of the main ways that the reduction of slavery into an individual harm paradigm occurs. Zoe Trodd, one of Antislavery Usable Past's investigators, has previously argued that contemporary advocates 'repeat the same mistakes' of paternalism, sensationalism, objectification, and 'white emancipatory fantasy' by recycling the abolitionist tropes of supplicant slaves, scourged backs, auction blocks, and slave ships. ${ }^{16}$ To her cogent list of 'mistakes' I add minimisation. The first three tropes historically pictured a single enslaved person who is or has been the victim of interpersonal physical violence or maniacal greed. In these tropes, both the victims and the perpetrators are individualised, excised from the larger social contexts that produced them. Diminishing the significance of slavery to individual acts of sadism and greed edits out the societal systems of racialised social control and reproductive management that racial chattel slavery created and relied on, many of which inhere in the present. Considering the magnitude of the terror of the system of racial chattel slavery and its global structuring power, reducing it to predominantly interpersonal violence is a large feat. It raises the question: in whose interest is it to understand racial chattel slavery in the good versus evil frame so widely promoted by anti-trafficking advocates?

Turning slavery into an individualised evil that is out of place in civilised and modern societies has been an ongoing discursive project, compounded by the centuries-long denial and erasure of how racial chattel slavery co-constituted

Bois, The World and Africa, Oxford University Press, Oxford, 1946/2007; W Rodney, How Europe Underdeveloped Africa, Bogle-L'Ouverture Publications, London, 1972; N Singh, 'Racial Formation in an Age of Permanent War' in D M HoSang, O LaBennett and L Pulido (eds.), Racial Formation in the $21^{s t}$ Century, University of California Press, Berkeley, 2012, pp. 276-301; J Melamed,'Racial Capitalism', Critical Ethnic Studies, vol. 1, issue 1, pp. 76-85.

14 See for instance: C L R James, The Black Jacobins: Toussaint L'Ouverture and the San Domingo revolution, Vintage, 1938/1989; C W Mills, The Racial Contract, Cornell University Press, Ithaca, 1997; S Wynter, 'Un-settling the Coloniality of Being/ Power/Truth/Freedom: Towards the human, after man, its overrepresentation', CR: The New Centennial Review, vol. 3, issue 3, pp. 257-338; S Hartman, Scenes of Subjection: Terror, slavery, and self-making in $19^{\text {th }}$ Century America, Oxford University Press, Oxford, 1997.

15 Made in a Free World, website, https://madeinafreeworld.com/.

16 Z Trodd, 'Am I Still Not a Man and a Brother?: Protest memory in contemporary antislavery visual culture', Slavery and Abolition, vol. 34, issue 2, 2013, pp. 338-352. 
modernity, ${ }^{17}$ to name just one aspect. I focus here on how this discursive project manifests in the Antislavery Usable Past not to attribute full blame to that project or identify it as the root of the problem. Antislavery Usable Past offers one of many examples of this phenomenon within the anti-trafficking discourse. This initiative bears special attention, though, because of its stated investment in bringing the anti-trafficking message to public institutions of black history in Britain and the US, which in the US context have been historically underfunded and undervisited by dominant groups, and have faced undue struggles to justify their importance within American society.

\section{Antislavery Usable Past}

The Antislavery Usable Past is a project funded by the UK Arts and Humanities Council's programme called 'Care for the Future'. It brings together a constellation of stakeholders interested in 'making the antislavery past usable for contemporary abolition', including history scholars, anti-trafficking NGOs, public history organisations, lawyers, artists, and museums that preserve the history of chattel slavery and abolition in the US and the UK. Its project investigators are the wellknown anti-trafficking scholar-advocates Kevin Bales, Zoe Trodd, Jean Allain, and John Oldfield. Through a series of videos on the project website, viewers are introduced to a wide range of initiatives that the investigators are launching, including: building and digitising archives of the commemoration of the abolition of the slave trade in Britain, creating a postdoctoral programme, generating new visual culture about anti-trafficking, producing an exhibition about Congolesenineteenthcentury abolition, developing workshops for museums and historic sites to incorporate anti-trafficking, and promoting new legal parameters about slavery, among others. Although the project is based in the UK, it circulates through and has implications for the American present for several reasons: organisations from both the UK and the US are involved in carrying out component projects; some of its visual representations of racial chattel slavery depict scenes in the US and/or come from both US and UK abolitionist producers which circulated widely in the eighteenth and nineteenth centuries; and several of its contemporary images were created by US-based artists or organisations.

17 See for instance: P Gilroy, The Black Atlantic: Modernity and double consciousness, Harvard University Press, Cambridge, 1993. Julia O'Connell Davidson also takes up this point in Modern Slavery: The margins of freedom, Palgrave Macmillan, 2015. 
The breadth of the push to institutionalise and legitimise the language of slavery within anti-trafficking is alarming, especially in light of the preview the website offers about the visual and affective strategies Antislavery Usable Past will utilise to suture the terms, and their histories, together. I unpack the website's promotional images below to show how they reduce, decontextualise, and flatten complex histories in order to make them appear visually similar. The primary strategy is to simply juxtapose images of racial chattel slavery and images suggestive of human trafficking. But what exactly is being compared? The pairs appear to show that antitrafficking advocates are using the same rhetorical strategies as nineteenth-century abolitionists because the problems are both 'slavery'. But all that the pairs really show is evidence that the anti-trafficking apparatus has appropriated the imagery of abolition for its own reasons. Advocates then use those appropriations as visual evidence that the issues themselves are the same. It is a self-fulfilling argument that uses and creates archives as its alibi.

\section{Image Selectivity}

Antislavery Usable Past makes the past usable for the present by comparing still frames of individuals from different centuries in similar poses, devoid of circumstantial information. Several paradigmatic image pairs populate the banner head of the website's pages. In one, a historic etching of seven young black boys huddled together wearing only loincloth is juxtaposed to a contemporary photograph of seven young shirtless South Asian boys posing together in a doorway. The comparison implies young boys have been enslaved then and now (in different places). Their poses and the similar image composition imply that their conditions are the same. Yet, the ambiguity of the images, compounded by a lack of image captions, means that viewers actually learn almost nothing about either group's situation, not least the conditions under which the images were made.

Other pairs follow the same format: an image of enslaved black people from the eighteenth or nineteenth century precedes an image of exploited individuals from the twenty-first century. While all the historic images feature black subjects, the contemporary images feature white, brown, and black subjects in situations that have become paradigmatic of the trafficking discourse: sex work in the US and South Asia, brick kilns in India, mines in Africa. The choice of the contemporary images renders today's injustices as multiracial and not race-specific, unlike the injustices of the past, while signalling that human trafficking spans many sectors of the economy. Several of the image pairs are not about the relationship between past and present exploitation, but about the similarities in past and present abolitionist visual culture. The pairs that focus on advocacy efforts are doubly layered: they draw attention to how advocates are using similar rhetorical schemes to agitate for change but the website does not note that this tactic is intentional. What the image similarities show is simply that anti-trafficking has, in fact, repurposed key abolitionist imagery for its own agenda. These comparisons are especially troubling because Antislavery Usable Past's website is reproducing some 
ANTI-TRAFFICKING REVIEW 9 (2017): $14-30$

of the exact same images and same limiting tropes that Trodd has criticised and that I further analyse below—slave ships, supplicant slaves, and auction blocks. ${ }^{18}$

\section{White Paternalism}

A prominent image pair on Antislavery Usable Past's main page features two adjacent medallions. On the left, the famous nineteenth-century image of a black woman kneeling with her bound hands stretched upward is pleading for recognition. The words 'Am I not a Woman \& a Sister, 1838' are carved on the token. On the right, a digital reproduction of the token displays a young white girl wearing torn clothing sitting with her face buried in her lap in shame. The contemporary token bears the message, 'Am I not a daughter and a sister? 2010'. Both of these images depict abolitionist strategies for appealing to white moral conscience to end exploitation. As such, they compare both the abolitionist strategies and the exploitation that the strategies aimed to ameliorate. The pairing materialises the Antislavery Usable Past's mission that the successful activist methods of nineteenthcentury anti-slavery campaigns can be directly applied to human trafficking.

In comparing the communication strategies of the two campaigns, the project also equates the issues and the types of violence, which problematically instrumentalises black suffering. The nineteenth-century token makes the critical claim of 'Woman' a demand for the recognition of enslaved people as Human. ${ }^{19}$ The twenty-firstcentury appropriation changes this ontological demand into the moral sentiment of 'daughter', which is a rhetorical tool to sentimentalise the innocence of young white women who need to be saved (by white men and white women). To be sure, sentimentalism also punctuated white abolitionist texts of the nineteenth century, including depicting enslaved people in inferior positions to signal their victimhood, helplessness, or passivity, ${ }^{20}$ attributes of the visual culture that derived from the white male gaze itself.

18 My study is analytically focused on how the website is composed because that is the primary, and in some cases only, information that viewers will receive about the images. Some of the images referenced in Z Trodd, 2013 are cropped on the website. In one case, a human rights organisation's logo and campaign slogan is completely removed from the frame, furthering the visual confusion about what the image represents.

19 On slavery and the Human, see S Wynter, 2003.

20 Z Trodd, 2013 makes this point specifically about the same medallion in order to argue, importantly, for representations of contemporary victims as survivors who represent themselves, which she characterises as more agential and as part of a 'less abusive usable past'. Similarly, in her To Plead Our Own Cause: Personal stories by today's slaves, co-edited with Kevin Bales, 2008, the editors argue for using the genre of the slave narrative to increase agency in representation. However, 'contemporary slave narratives' can be problematic in their own ways. They are often elicited by NGOs or government agencies that have their own political or fundraising agendas 
Presenting organising campaigns as if they are instantly transferable to other social issues, and framing such transfers as good and effective, does nothing to help audiences understand how power works in different situations of exploitation, nor what will be effective ways to intervene on and shift such oppressions. What it does do, however, is claim that the prostitution of white girls is just as bad, just as widespread, just as morally egregious, and just as urgent as the centuries-long systematic enslavement and racialised social and reproductive control over black women. As a black woman begs to be recognised by a white patriarchal society that secured its wealth and power through her rape and forced reproduction, ${ }^{21}$ a white woman sits ready to be rescued and protected by that same powerful white man, who rescues his conscience and complicity in the process. Such juxtapositions erase the ways that white male domination over black women actually creates and upholds white female innocence. It is that same innocence which makes white women rhetorically available to be objects worthy of being rescued from sexual defilement. White male heroic protection, the alibi of the US slave state, is constructed through the figure of the agentless white female, who depends on the security that white men can provide, a security that is accumulated and granted to those men through the history of racial chattel slavery, ideology of white supremacy, and the system of white privilege it produced and depends on. Despite deriving from drastically different, although entwined, systems of oppression, the juxtaposed medallions communicate the sameness of the issues by utilising interpretive closure. Two women, two tokens, two slogans, make the case that these issues are similarly important; two different media and two different subjects on the coin alert viewers to the newness of the contemporary cause and the closed case of the past issue.

\section{White Accumulation}

A second set of images on the website compares women being sold at auction in 1864 and 2009. The first is a nineteenth-century drawing of an African American woman standing on an auction block with a downcast gaze, while two bidding white men gesture towards and sneer at her, and another calls for bids on her. The historic image is cropped from an American political cartoon but that context is not made available. It is followed by a contemporary photograph of a young South

for being involved with anti-trafficking. The narratives also produce particular types of victims that are deemed worthy of help, which leaves out other types of exploited individuals and other types of agency, most saliently, the various types of agency exhibited by sex workers who do not want to be 'rescued' by the anti-trafficking industry. See L M Agustín, Sex at the Margins: Migration, labour markets and the rescue industry, Zed Books, London, 2007.

${ }^{21}$ J L Morgan, Laboring Women: Reproduction and gender in New World Slavery, University of Pennsylvania Press, Philadelphia, 2004. 
Asian woman in a Plexiglas box. The placard attached to the box reads, 'Child Prostitute, Bangladesh, c. 2009'. Neither image is captioned or credited. The historic image turns out to be a small section of the Harper's Weekly illustration titled 'The Chicago Platform. Union Failures'. That political cartoon critiqued the Democrat Party in an election year during the American Civil War by juxtaposing its platform with scenes of the violence those policies upheld, including slave auctions and slave floggings. ${ }^{22}$ The production of the image matters in order to understand what work it was intended to do in the past and what representational liberties the artist might have taken. Still, we know that such scenes did in fact take place and in ways quite similar to the one depicted. Enslaved black women, like other enslaved people, were frequently sold at auctions, inspected like cattle, and fondled and humiliated in the process.

A black woman on the auction block was an important mechanism of how the system of slavery was reproduced, especially after the abolition of the import of additional slaves. Rather than being simplified to 'women are sold, then and now', this image could convey that slavery was the engine of capitalism (rather than driven by a few sadistic, greedy, or misguided individuals) and that the black enslaved woman and her womb served as both the means of (re)production and the site of primitive accumulation. That is, the white slaver dispossessed black enslaved women of full autonomy over their wombs and then accumulated through expropriation the wealth produced therein (another enslaved person) ${ }^{23}$ While rape fuelled the capitalist slave society and economy, it cannot be elided with 'the sex trade' where sexual encounters are exchanged for money. One system generated the wealth and power-and cognate systems of dispossession - that more developed countries still enjoy today; the other is an experience of exploitation, sometimes to the extreme, and/or an occupation that is often, but not always, entered into under coercive conditions.

By contrast, the contemporary photograph of a young South Asian woman in a Plexiglas box is not indexical to how sex work or sexual exploitation function in Bangladesh. It certainly does not represent how child prostitution transactions take place, nor how or why they become systematised. While no context is provided, the photograph turns out to be a closely cropped portion of Save the Children Australia's 2009 campaign entitled 'We must make this a thing of the past'. That campaign created highly sensationalised photographs to raise awareness about injustices children face in the Congo, Kenya, and Bangladesh.

2 Library of Congress object file, accessed at: http://www.loc.gov/pictures/item/ 2008661665/.

23 H Spillers, 'Mama's Baby, Papa's Maybe', Diacritics, vol. 17, issue 2, 1987, pp. 64 81; S Hartman, 1997; J L Morgan, 2004. 
The woman is staged in the box with the placard to make a point. The box symbolises being trapped, objectified, shipped, and commoditised for sale, which are all implicit references to the transatlantic slave trade. The box and placard also suggest the dehumanising ethnographic displays of various human 'species' at nineteenth-century Worlds Fairs (many of whom were black). These historic references to situations that were actually endured by black people are repurposed as metaphors to explain how immoral and terrible child prostitution is. Child prostitution is certainly terrible, but such rhetorical sensationalism does nothing to help us understand what causes it or how to end it. It only implies that (1) not enough attention is being paid to this issue and (2) child prostitution should be fought against as vociferously as the transatlantic slave trade. Using the museum labelling convention 'c. 2009' further suggests two things: first, that these advocacy efforts could end such practices, relegating them to 'history ${ }^{24}$ and museums; and second, that Bangladeshi culture participates in barbarous practices from the past that have no place in a modernised and civilised future. The latter reiterates racist stereotypes of the global South, including the idea that brown women from less developed countries need to be saved by white feminism. ${ }^{25}$

Two women, both being objectified and sold, are rendered the same through their juxtaposition. They are both positioned in the frame as auctionable items. Yet, this positioning is only possible because the second image comes out of using the metaphor of slavery and its imagery to advance the cause in the first place. Placing images side by side purports to show visual evidence of something, but what it confirms is only that anti-trafficking advocates have a long history of appropriating the imagery of racial chattel slavery and its abolition. The systems of oppression are not the same; the strategies to end them will not be the same; the points that do converge - the effects of capitalism's accumulation through dispossession via colonialism or enslavement-are not discussed. So, what work do these appropriations do for anti-trafficking?

24 Although cropped from view, the original Save the Children Australia posters that this image comes from bear the slogan: 'We must make this a thing of the past.' Full campaign viewable at: http://adsoftheworld.com/campaign/save-the-children-mcsaatchi-10-2009.

25 C T Mohanty, 'Under Western Eyes: Feminist scholarship and colonial discourses', Feminist Review, vol. 30, 1988, pp. 61-88; K Kempadoo, 'The Modern-Day White (Wo)Man's Burden: Trends in anti-trafficking and anti-slavery campaigns', Journal of Human Trafficking, vol. 1, 2015, pp. 8-20; G C Spivak, 'Can the Subaltern Speak?' in C Nelson and L Grossberg (eds.), Marxism and the Interpretation of Culture, 1988, pp. 271-313. 
ANTI-TRAFFICKING REVIEW 9 (2017): $14-30$

\section{White Comfort}

The Antislavery Usable Past is not only concerned with trafficking for sexual exploitation. A third image pair presents exploited labourers in 1845 and 2009. The first appears to be a nineteenth-century etching of enslaved African American men and women working on a Southern cotton plantation. It is followed by a twentyfirst-century photograph of brown men making bricks. Although neither is captioned or located in space (only in time), both images depict the difficulty of the manual labour that the subjects are engaged in. The first image is a classic representation of racial chattel slavery in the southern United States, where enslaved African Americans work the land and heave large baskets of picked cotton onto their shoulders. The second image is framed similarly, but the distressed working conditions are not as iconic or identifiable, although they are quickly becoming paradigmatic of 'modern day slavery' through NGO promotion of this type of exploitation. ${ }^{26}$

The image juxtaposition uses literal, repeating visual cues to heighten the comparison of the exploitation. In both images, individuals have their heads adorned with cloth wraps and are using tools. The central figure in both images, a male, is captured mid-action: in the nineteenth-century carrying a basket of cotton and in the twenty-first century, swinging a hoe overhead. In the foreground of the photograph, men squat with bricks piled on their heads, a visual convention that communicates difference to western viewers due to its association with the practices of poor people in Africa and Asia. The images communicate the sameness of these systems and experiences of labour exploitation by depicting the conditions as visually similar and magnifying their similarity by framing the labouring bodies in the same poses. The images suggest that 'slavery still exists' by situating the viewer in a familiar scene of racial chattel slavery — which cues the word 'slavery' in a viewer's imagination - and then jumping to a completely different scene of dire working conditions abroad in the present. Not only is this new slavery the same as racial chattel slavery, the image suggests, it continues to happen in less civilised places than the US. This comparison, then, works to consign racial chattel slavery to the completed past; a historic mistake that the Americans and the British can feel good about ending 150 years ago. It appeals to the would-be abolitionists' sense of nonracism by encouraging them to get involved today to free people in places more backward than the global North. It also names a new racialised victim in relation to

26 The historic image labelled 1845 is elsewhere captioned Picking Cotton, U.S. South, 1873-74 (in University of Virginia archive), potentially making it an image of labour after emancipation. The photograph of the South Asian labourers was taken by Lisa Kristine in the Kathmandu district of Nepal and appears in her photobook Slavery, which she produced through her partnership with the NGO Free the Slaves. 
racial chattel slavery: not the black American who endures anti-black racism structurally and interpersonally today, but the brown global Other, implicitly seen as a more worthy and less threatening victim, precisely because of how anti-blackness shapes white American consciousness.

The image pairs on the Antislavery Usable Past website attempt to 'give meaning to new instances of horror by contextualizing them against earlier brutality. Yet, in so doing, they flatten the complexity of the original event ${ }^{27}$ while also misinterpreting the contours of human trafficking by trying to fit it into familiar narratives of slavery. Such pairings do a lot of discursive work to render both the history of racial chattel slavery and the problem of human trafficking into histories and presents that are not threatening to white subjectivity: racial chattel slavery was bad, but is over and has no relevance to contemporary American and British life. Contemporary work conditions abroad are upsetting, but not caused by me, my structural position, or my country's policies. However, these pairings teach viewers very little about either injustice, the systems that proliferate and support them, or how we might work to end, ameliorate, or intervene on the present-day manifestations of both.

The project, then, makes the past usable by hollowing out the rich stories and contemporary structural connections the archives of slavery hold. Such reductions, decontextualisations, and appropriations have large stakes for how we understand the histories that have produced our worlds, and to what ends we use them. Why are the anti-trafficking uses of abolitionist history so thoroughly legitimised, funded, and institutionalised? Why do histories of black suffering more easily gain mainstream political traction when they are used as a metaphor or a cautionary tale for other oppressions? Rather than 'care for the future', such appropriations demonstrate a profound lack of care for, and towards, black humanity and the ongoing black liberation struggle.

\section{The Public History of Slavery}

The promotional images that I have analysed provide a window onto how Antislavery Usable Past mobilises history for its cause. While it might be tempting to dismiss a few images on the website as opportunistic rhetorical sensationalism, the interpretive closure that Antislavery Usable Past's website uses excises the contours of the history of racial chattel slavery to make it more easily appropriated for antitrafficking advocates. The project also sees its mission as working in the reverse direction. One of the arms of the Antislavery Usable Past project aims to bring the

27 Zelizer, 1998, p. 206. 
anti-trafficking message to historic sites and museums of slavery and abolition through a series of seminars that will encourage museums to think 'about the use of contemporary slavery in exhibits that would otherwise be focused only on historic slavery'. ${ }^{28}$ These scholars see the need to 'emphasize contemporary slavery' because it is 'often neglected' in spaces focused on historic slavery. ${ }^{29}$

Such statements raise several concerns. The use of the word 'only' suggests the history of slavery does not merit its own institutions. In a political environment where it remains difficult and controversial to address histories of slavery at all, let alone fund and build institutions or monuments focused on them, such dismissal of the struggle for the public history of slavery is inappropriate, careless, and selfaggrandising. Further, naming 'contemporary slavery' as an object of neglect suggests that the history of racial chattel slavery has received more than enough attention (it has not), when in fact, it is human trafficking that continues to garner the attention and investment of billionaire philanthropists and lawmakers alike. These antitrafficking claims raise important questions: Why should public museums of history and abolition add trafficking exhibitions? Is it only because anti-trafficking advocates have effectively conflated the terms trafficking and modern day slavery through extensive public relations and lobbying? And what is at stake if those public history institutions take up this new mandate?

The Antislavery Usable Past lists memory institutions among its partners, including the International Slavery Museum in Liverpool, England, and the Slave Trail in Richmond, Virginia. The International Slavery Museum has already incorporated anti-trafficking materials into one of its exhibition spaces. Anti-trafficking exhibitions and/or materials have been incorporated into other public history institutions as well, including The National Underground Railroad Freedom Center in Cincinnati, Ohio, Lincoln's Cottage in Washington, D.C., and the Oberlin Heritage Center in Oberlin, Ohio. The exhibitions and materials at all of these institutions have focused on advertising the mission and imagery of anti-trafficking NGOs and the US Department of State. In addition to the interpretive closure and conflation already operating within the practice of comparing racial chattel slavery and human trafficking, the presentation of evidence within the museum space is further distorted by the often sensationalised and Othering depictions of trafficking victims in NGO materials. Displaying these types of exhibitions alongside the careful historical documentation of many museums of slavery and abolition threatens to undermine the latter while magnifying the horror of the former.

28 Trodd video, available at http://www.usablepast.ac.uk/projects/index.aspx.

29 Oldfield video, available at http://www.usablepast.ac.uk/projects/index.aspx. 
My ultimate concern about the adoption of anti-trafficking in sites of history of slavery and abolition is how the connections threaten to 'cannibalize ${ }^{30}$ histories of oppression that remain crucially relevant to understanding contemporary structures of anti-blackness. The desire to compare different historic and contemporary violences in order to promote action has very real stakes in this instance, where the referent pain and injustice is not confined to the past but is ongoing, where attempts at redress have not been triumphant, only contested and controversial, and where the simple assertion that black lives matter has been labelled terrorism. Public institutions of the history of slavery and abolition play an important role in connecting anti-black pasts with anti-black presents. Since anti-blackness is an ongoing structural problem, histories of slavery can help audiences understand how the systems of oppression shift post-Emancipation. The American historiography charts out several: the Black Codes, convict leasing, segregation, racist exclusions from social programmes and unionisation, and mass incarceration.

Yet, using 'modern day slavery' as the contemporary connection to such histories redirects attention, energy, space, and money to other social causes. 'Contemporary anti-slavery' campaigns are most often represented in museums through the vision of major western-based NGOs and US and British laws and policy, which tend towards punitive measures, criminalisation, law enforcement training and reform, supply chain transparency, and business-based solutions. All of these proposed solutions are supportive of industries that uphold anti-blackness. In the case of police and criminalisation, these institutions and discourses were explicitly coconstituted with slavery and anti-blackness. ${ }^{31}$ By inserting anti-trafficking discourse in spaces of historic memory, not only is education about why and how antiblackness endures in the present displaced, potential exhibitions that link ending slavery to ending mass incarceration, for instance, are converted into exhibitions that promote, normalise, and enhance criminal legal systems. Ceding the central, accessible, and public pedagogical space of the museum to causes that bolster institutions premised upon anti-blackness is a stunning display of recuperation. Doing so through the memory of slavery manifests a long-voiced critique from black movement leaders, rearticulated as recently as the US Women's March on Washington in January 2017: 'Here they go again... adopting the work of black people while erasing us. ${ }^{32}$

30 B Zelizer, 'Cannibalizing Memory in the Global Flow of News' in M Neiger, O Meyers and E Zandberg (eds.), On Media Memory: Collective memory in a new media age, Palgrave Macmillan, 2011, pp. 27-36.

31 See for instance: K Muhammad, The Condemnation of Blackness: Race, crime, and the making of modern urban America, Harvard University Press, 2011; L Beutin, 'Racialization as a Way of Seeing: The limits of counter-surveillance and police reform', Surveillance \& Society, vol. 15, issue 1, 2017, pp. 5-20.

32 A Garza, 'Our cynicism will not build a movement. Collaboration will', Medium.com, 26 January 2017. 
ANTI-TRAFFICKING REVIEW 9 (2017): 14-30

It remains to be seen how the various components laid out on the Antislavery Usable Past's website will play out on the ground and what will come of the project, including the public history initiatives. It is my sincere hope that such projects will not re-centre trafficking in these critical memories of slavery. My point in this article has been to raise the following meditations on the stakes and implications of such archival projects. What we can lose in the conflation of these discourses is necessary and continued attention to how and why anti-blackness manifests in the United States and across the globe. What we lose sight of is how the structural exclusions that colonialism and the transatlantic slave trade forced upon the global South create systems of poverty and oppression that help facilitate human trafficking. What we potentially gain, instead, is another project that does not fully consider, nor take accountability for, the political stakes of the appropriation of black suffering, the implications of its imagery on other people and other causes, or the collateral damage (always already racialised) a well-intended project can cause. Perhaps, then, the lesson that anti-trafficking advocates need to learn from history is that the commodification of black suffering may increase the freedoms of some, but has not, and will not, lead to freedom for all.

Lyndsey P. Beutin is a doctoral candidate at the Annenberg School for Communication at the University of Pennsylvania. She currently holds a pre-doctoral fellowship at the Carter G. Woodson Institute for African-American and African Studies at the University of Virginia (2016-2018). Her research focuses on the memory of slavery in the US, liberalism and anti-blackness, systems of redress for racial injustice, and state legitimacy. Her dissertation is a media ethnography of the phrase 'modern day slavery' in the multi-platform campaign against human trafficking. Email: Lbeutin@upenn.edu 


\title{
'The New Order of Things': Immobility as protection in the regime of immigration controls
}

\author{
Nandita Sharma
}

\begin{abstract}
In this paper, I discuss two 1835 ordinances passed by the local council of the British colony of Mauritius. Passed shortly after Britain's 1833 Slavery Abolition Act, these restrictions initiated the regulation and restriction of immigration within the British Empire. Seen as quite novel in their day, these ordinances employed the rhetoric of 'protecting emigrants' to legitimise the new constraints they imposed on free human mobility. Today, when the national 'logic of constraint' on human mobility is almost uncontested, the idea that immigration controls protect migrants remains central to the discursive practices concerning human trafficking. Nationstate constraints on human mobility are normalised while the exploitation and abuse of people on the move is ideologically redirected to 'modern-day slavers' or 'evil traffickers', thus absolving both the state and globally operative capital of their culpability.
\end{abstract}

Keywords: coolieism, slave labour relations, human mobility, immigration controls

Please cite this article as: N Sharma, “The New Order of Things": Immobility as protection in the regime of immigration controls', Anti-Trafficking Review, issue 9, 2017, pp. 31-47, www.antitraffickingreview.org

\section{Introduction}

To better understand and historically situate efforts to end 'human trafficking' or 'modern-day slavery', I examine the period in which regulations and restrictions on free human mobility into state territories—immigration controls—were first enacted. This is important for at least two reasons. First, like today's anti-trafficking policies, the initial, nineteenth-century organisation of border controls centred a narrative of 'rescue and protection' in order to normalise the regulation of people's immigration, a practice seen as wholly novel and an illegitimate exercise of state

This is an open-access article distributed under the terms of the Creative Commons Attribution License (CC-BY) Under the CC-BY license, the public is free to share, adapt, and make commercial use of the work. Users must always give proper attribution to the authors and the Anti-Trafficking Review. 
power at that time. Second, without the all-encompassing system of contemporary nation-state controls on human mobility, the intermediaries that people currently rely on to facilitate their movement into state territories - and the opportunities for a livelihood located there-would lose much of their power.

The beginning of the end of relatively free immigration, i.e. lawful entry into a state's territory, is not a timeless and integral element of a state's sovereignty, or even a characteristic of the sovereignty of a territorial state as set out by the 1648 Treaty of Westphalia; it is a part of the politics surrounding the abolition of slavery within the British Empire. Immigration controls are intimately connected to the replacement of the slave trade with the pejoratively termed 'coolie' labour trade in indentured, contract labour, mostly from British-colonised Asia. ${ }^{1}$ The 'coolie' labour system rested on a legal requirement for workers to labour for a contracted period of time (usually five years but sometimes shorter or longer). During this period, they were tied to the contracting employer and were not free to change either their employer or place of work. ${ }^{2}$ The 'coolie' system of labour recruitment acted as a bridge between what Radhika Mongia terms the imperial-state 'logic of facilitation' of human movement and the national-state 'logic of constraint'. By examining the emergence and growth of regulations and restrictions on human mobility within the politics of anti-slavery, efforts to discipline labour and the growing power of nationalist discourses over capitalists, workers, and colonial officials, we can evaluate both the claims made and the solutions offered by contemporary anti-trafficking frameworks which purport to assist migrating people.

The first regulations governing mobility within the British Empire were enacted in 1835 in the colony of Mauritius against 'coolie' labourers moving from one part of the Empire (British India) into another (British Mauritius). These first immigration controls were brought in through a range of concerns, some of which were conflicting and contradictory, but most of which intended to secure a new labour force for sugar plantation owners on the island of Mauritius in the Indian Ocean, about 2,000 kilometres off the southeast coast of continental Africa. The London colonial office was intent on constructing a labour recruitment system that would replace slavery, but one that would not be portrayed as such by abolition activists. With the impending end of slave labour relations, the local Mauritian colonial authorities were intent on sufficiently disciplining the workers brought in from British India. Meanwhile anti-slavery campaigners signalled their intent to 'protect'

1 The term 'coolie' has from the start been imbricated with deeply racist meanings. Hence, my placement of it within quotes.

2 L Potts, The World Market for Labour Power: A bistory of migration, Zed Books, London, 1990, p. 79.

3 R V Mongia, 'Historicizing State Sovereignty: Inequality and the form of equivalence', Comparative Studies in Society and History, vol. 49, no. 2, 2007, pp. 384-411. 
'coolies' from would-be slavers. Regulating and restricting the entry of those recruited as indentured contract labour through the emergent 'coolie' labour system addressed all of these concerns. Such controls precipitated a new world order of nation-state regulations and restrictions of human mobility, one that has created many crises for people trying to move ever since, especially those seeking new livelihoods.

Of course, at the time, no one working in the British imperial-state's wide and dispersed apparatus could have known the long-range consequences of regulating the entry of British subjects from one part of its territories into another. Such regulations were initially piecemeal strategies imposed only on those moving through the 'coolie' labour system in response to economic and political crises of the moment. Nonetheless, the imposition of immigration restrictions on 'coolie' labourers emerged as a key part of the British imperial state's response to the threats to both its power and imperial trade posed by the abolition of the slave trade in 1807 and of slave labour relations in 1833.

\section{Imperial Logic on Human Mobility}

All states are concerned with controlling people's mobility in one way or anotherand they are interested in doing so for largely the same reasons. In this section, however, I lay out the different forms of mobility controls exercised by imperial states and by nation states. The distinction between the two, I believe, tells us much about the contemporary discourse — and nation-state practice_-of 'antitrafficking'. Imperial states ruled by making those subjected to their powers of taxation, levies, and forced labour into subjects of their empire. Generally speaking, the more subjects the state had within its territories, the more persons whose labour it could exploit, the more wealth it could amass, and the more power it could wield. Imperial states' concerns about borders and boundaries were, thus, primarily about preventing people from leaving. Holding people in its imperial territories was the sine qua non of its project of 'civilising' people ('civilisation' always having been an effect of state power). This was never an easy task. Many would-be imperial subjects, keen on making an escape, practised what James Scott has nicely termed 'the art of not being governed' ${ }^{4}$ and carved out non-state spaces for themselves wherever, whenever, and for as long as they could. Thus, in contrast to the Hobbesian story of sovereignty, where states were purportedly created by people to protect themselves from the violent chaos of an 'uncivilised' (i.e. stateless) life, in actuality, gaining sovereignty over people entailed much violence.

4 See: J C Scott, The Art of Not Being Governed: An anarchist history of upland Southeast Asia, Yale University Press, New Haven, 2010. 
Even for those unable to escape, however, imperial states were not interested in the wholesale immobility of their subjects. Rather, imperial states facilitated the movement of people into and across their empires. Indeed, imperial states were actively involved in such movements, often on a massive scale, even as they then immobilised most people through labour relations of unfreedom. European empires, since the late fifteenth century, actively engaged in moving people through systems of slavery, impressment, debt bondage, penal transport, servitude, and, in late imperialism, immigration regimes. All of these were structural elements of imperialism. ${ }^{5}$ Indeed, facilitating human mobility was crucial for the profitability of imperial territories, particularly as colonialism resulted in the high death rates of the colonised, itself often a result of their enslavement. ${ }^{6}$ Moreover, the high death rate of enslaved persons from Africa, from Europe and Asia indentured labourers, and even of socalled free labour, also required an ongoing replenishment of labour power in the colonies.

One of the first main systems of moving people within a rapidly globalising space of imperialism was the trade in slaves from largely the west coast of Africa, a labour system that was dramatically altered with the introduction of capitalist market imperatives. The world-historical shift that came with the delegitimisation of the slave trade and of slavery itself was undoubtedly the result of the centuries-long and countless acts of rebellion of the enslaved, along with the efforts of those who joined them in an organised movement to abolish slavery. In the late eighteenth century, these latter efforts intensified and did so from within the centre of the British Empire itself-the City of London. ${ }^{7}$ With its 25 March 1807 Abolition of the Slave Trade Act, the British Empire ended its trade in slaves from Africa. Yet, due to the heavy reliance on slave labour by plantation owners and the imperial treasury, the institution of slavery itself was maintained within the Empire for several decades afterwards, and in some imperial territories even for several years following the passing of Britain's Slavery Abolition Act of 1833.

\footnotetext{
Potts, p. 204.

6 A Reséndez, The Other Slavery: The uncovered story of Indian enslavement in America, Houghton Mifflin Harcourt, 2016; B Rushforth, “A Little Flesh We Offer You”: The origins of Indian slavery in New France', The William and Mary Quarterly, vol. 60, no. 4, 2003, pp. 777-808; L Behrendt, as interviewed in Servant or Slave, DVD, directed by Steven McGregor, No Coincidence Media, 2016; M Tate and F Foy, 'Slavery and Racism in South Pacific Annexations', The Journal of Negro History, vol. 50, no. 1, 1965, pp. 1-21.

7 A Hochschild, Bury the Chains: Prophets and rebels in the fight to free an empire's slaves, Houghton Mifflin, New York, 2005; P Linebaugh and M Rediker, The Many-Headed Hydra: Sailors, slaves, commoners, and the bidden history of the revolutionary Atlantic, Beacon Press, Boston 2000.
} 
The main reason for the decades-long gap between the end of the British slave trade (1807) and the end of slave labour relations (1834-1843) was the search for a system of labour recruitment that could replace it and do so in a manner that met investors' demands for a cheapened and weakened workforce. The central issue was that of rights. What, if any, rights would the workers recruited to replace enslaved workers have after the abolition of slavery? And from where would these workers be recruited? In this there was no uniform response. The post-abolition period saw a dramatic increase in people recruited from Europe for a variety of work. They did not face any restrictions on their movement to the places they came to until well into the twentieth century. However, by the early nineteenth century, the growing numbers of workers arriving from Europe were less and less likely to be employed in unfree employment relations. ${ }^{8}$ Moreover, already by the seventeenth centuryand certainly by the end of the eighteenth century—a racialised division of labour had been established, resulting, amongst other things, in a highly differential pay scale between workers racialised as white and those racialised into various categories of non-whites. This was especially the case in the 'white-settler colonies' (e.g. United States, Canada, Australia, New Zealand) where the ratio of whites to non-whites had been reversed earlier on. The higher 'wages of whiteness' meant that the search for the most profitable way to replace enslaved workers did not end with the increase in people from Europe. ${ }^{9}$ The new-found freedom of white male workers from conditions of indentureship resulted in a substantially lessened ability for employers to exercise control over them. Free labour relations, politically empowering to (mostly white male) workers, were seen to be too costly by employers. In any case, white people did not migrate in large numbers as workers outside of the 'white-settler colonies'.

8 It is estimated that more than half of all persons moving from Europe to the English colonies of North America during the seventeenth and eighteenth centuries came as indentured servants (see Potts). Some of the workers brought to replace slave labourers in the New World came from Europe. However, until the abolition of the slave trade in 1807, the number of Africans throughout the Americas outstripped the combined total of Europeans by a ratio of 3:, 4:, or even 5:1. Between 1492 and 1820, while approximately ten to fifteen million Africans were forcibly brought to the New World, only two million or so people from Europe had made the journey. This only began to change after the abolition of the African slave trade and, even then, only in the 1820s. See: J Steinfeld, The Invention of Free Labour: The employment relation in English and American law and culture, 1350-1870, University of North Carolina, Chapel Hill and London, 1991.

9 D R Roediger, The Wages of Whiteness: Race and the making of the American working class, Verso, London, 1999. 
ANTI-TRAFFICKING REVIEW 9 (2017): 31-47

\section{The Abolition of Slavery and the Start of Coolieism}

The more effective 'solution' to the problem that imperial states and capital investors faced with the end of slavery was the 'coolie' system: the system of recruiting and exploiting already negatively racialised people, mostly men, and mostly from Britishcontrolled China and India, to work in conditions of indentured servitude. ${ }^{10}$ Indeed, coolieism became the dominant system through which people were moved within the world market for labour, from approximately 1830 to the 1920 s. $^{11}$ While there is no definitive number of how many people were moved as 'coolies'some estimate a low of 12 million while some argue that 'an estimate of 37 million or more would not be entirely without foundation'- the scale and significance of the 'coolie' system were, even with the lowest estimates, comparable to those of slavery. ${ }^{12}$ Indeed, the 'coolie' system surpassed African slavery in its intensity, as millions of 'coolies' from Asia were recruited and exploited within the range of slightly less than a hundred years (1830s-1920s). ${ }^{13}$

While Britain's Slavery Abolition Act of 1833 did not go into effect in the territories controlled by the East India Company (or Ceylon) until 1843, the introduction of capitalist social relations in British India and British-controlled China resulted in a 'surplus population' desperate for a livelihood. Increasingly, most people had to engage in capitalist markets, including for labour, for their continued existence, and by the 1830s and 1840s, millions of people were ripe candidates to be exploited as 'coolies' throughout the British Empire in Asia, Africa and the Americas.

As they were moved throughout the British Empire, the relationship of 'coolies' to the still- or soon-to-be former slaves — and to the institution of slavery-was called into question. The main question was whether coolieism was a new form of slavery or not. As I discuss below, distancing coolieism from slavery formed the foundation for the establishment of immigration regulations and restrictions in the British Empire. In other words, it was the impending end to slave labour relations which led to the enactment of the very first controls on in-migration. And, it was against 'coolies' from Asia, employed on contracts of indenture, that a growing list of regulations to monitor the mobility of co-imperial subjects were first ordered. ${ }^{14}$

10 The India Act of 1858, inaugurating the period of British rule referred to as the Raj (or British India), transferred authority over most parts of the South Asian subcontinent from the British East India Company (which had ruled it from 1757) to the British Crown. Under the 1842 Treaty of Nanking, the British gained direct control over Hong Kong and Canton, Shanghai, Amoy, Fuzhou and Nigbo were opened up as nodes in the British-organised and controlled trade in opium.

11 Potts, p. 69.

12 Potts, pp.71-73.

13 Potts, p. 73.

14 Potts, pp. 68-71. 
Specifically, as Radhika Mongia's study shows, it was in the British colony of Mauritius where the first efforts to regulate the immigration of co-British imperial subjects took place. It was a monumental shift, one that generated much heated discussion at the time. ${ }^{15}$ The local colonial government of Mauritius's effort to regulate and restrict the entry of 'coolie' workers from British India marked a shift from imperial concerns about exit to new concerns about entry. In retrospect, it was the beginning of the end of the regime of the unrestricted entry of British subjects within imperial territory and, in a sense, the start of ideas of a fragmented imperial space, ideas which would fuel nationalist movements in the colonies, and eventually, in the metropoles of the Empire.

People from Africa had been enslaved on Mauritius since the emergent Dutch Empire first colonised it (1638-1710). Slavery there continued under the French (1710-1810) and under the British during its period of great expansion in the nineteenth and early twentieth centuries. On the eve of the British conquest of Mauritius in 1810, there were some 63,000 enslaved workers there. ${ }^{16}$ Sugar plantations reliant on slave labour from Africa soon became the mainstay of the colonial economy. As the date for the abolition of slave labour relations on Mauritius in 1835 drew near, however, local British colonial officials became increasingly concerned about maintaining the profitability of the colony and, therefore, its attractiveness to investors. ${ }^{17}$ In particular, given the harsh working conditions prevalent on sugar plantations, they did not believe the planters' intent to recruit workers from India to replace the soon-to-be freed slaves would solve the problem of securing a necessary labour force. This led the colonial government to look for a measure to immobilise the new workforce. Forcing enslaved people over the age of six to work for another three to five years as 'apprentices' temporarily accomplished this with regard to slaves, but the same measure did not solve the 'problem' of the newly freed workers from British India.

In 1835, the same year that slaves were freed on Mauritius, two ordinances regulating the migration of people from British India were passed by the local British Council (and ratified in 1837 by the British Parliament). ${ }^{18}$ These ordinances, meant to regulate and discipline 'coolie' workers from India, would only admit 'coolies' who had permission from the governor of the colony. This restriction limited the hitherto free mobility of 'coolie' labour from British India who, it is well worth remembering, were co-imperial subjects, theoretically on par with all other British

15 Mongia.

16 R B Allen, Slaves, Freedmen and Indentured Labouers in Colonial Mauritius, Cambridge University Press, Cambridge, 1999, p. 13.

17 With the abolition of slavery on Mauritius, the planters, not the enslaved, received a compensation of two million pounds sterling.

18 Mongia, p. 399. 
subjects. The Mauritius ordinances made a break with the previous imperial practice concerning migration. Indeed, such interventions were viewed as wholly novel and lacking in legal precedence. The imperial office admitted as much when it stated that 'this practice [of regulating migration] has no foundation in any existing law'. ${ }^{19}$

The shock of such mobility restrictions affected planters as well. They feared that these would be used to limit the number of workers they could recruit from British India. Consequently, one planter, Hollier Griffith, used the argument that any intervention into the movement of workers from India was unprecedented. Writing to G. F. Dick, the Colonial Secretary of Mauritius, Griffith noted that the imperial state might prohibit the departure of a British subject from British territory (but even then only in 'exceptional cases'); however, he maintained, the state's sovereignty did 'not extend so far as to prohibit the entrance into his dominions of any of his subjects' ${ }^{20}$ In other words, he argued that regulations and restrictions on immigration were not the purview of the British imperial state. In response, Mr Prosper D'Epinay, the newly appointed Protector General of Mauritius, defended the right of local Mauritian authorities to impose entrance restrictions on each new migrant, and argued that the ordinances were 'a measure of foresight and of internal police' without which there would be 'tumult and disorder [rather] than [an] increase in [the] industry of the country'. ${ }^{21}$

Clearly concerned about the changes wrought by the end of slavery on Mauritius and the colonial officials' desire for a disciplined labour force, D'Epinay further argued that,

wise and prudent precautionary measures [should] be taken ... when this new population is put into immediate contact with the new apprentices just emerging from slavery, still susceptible of every impression; and to whom it is of importance, at the first step towards civilization, to give [an] idea and examples of order, labour, discipline. This end would be frustrated, if permission were given to associate them with all the vagabonds and all the idlers with which India swarms.... Who can say what influence this medley of individuals, with their manners, their usages, and their vices will have on our indigenous population, especially when it shall become wholly free? ... It is the part of a wise Government to give to it serious attention; it is, therefore, necessary to proceed with caution in the new order of things. ${ }^{22}$

\footnotetext{
Mongia, p. 399.

Mongia, p. 400.

Mongia, p. 401.

Mongia, pp. 401-402.
} 
His claims for a 'new order' were not hyperbolic. In retrospect, the Mauritius ordinances were a striking shift in British policies on movement within its Empire. Significantly, while bowing to the still dominant (and formal) notion that British Indian subjects had the same rights as 'those who reside in any possession, territory, or dependency of Great Britain', D'Epinay, defended the elimination of this formal equality when he asked whether, 'the term British subject, and the privileges attached to it, are not according to places and circumstances, susceptible of important division and modification'. ${ }^{23}$ In the negotiations between colonial authorities on Mauritius and in London, the view in favour of regulating and restricting the movement of people from British India to British Mauritius won out and was the start of juridical distinctions between who could and could not move freely across the space of the British Empire. From 1835 to 1838, approximately 25,000 'coolie' labourers from India were shipped to Mauritius_of whom 7,000 died-thus alleviating planters' concerns that immigration ordinances would curtail the supply of labour.

Yet, although the Mauritius colonial officials were enthusiastic about immigration controls, neither the British Indian government nor the London Office were convinced. With the success of the slavery abolition movement, they felt it was crucial that the new 'coolie' labour recruitment system not be viewed as a new form of slavery. Nonetheless, realising the singular importance of 'coolies' for planters, both sets of colonial authorities came to support the Mauritius colonial government's regulations and restrictions on them. They did so by expanding the limits placed on their mobility by adding emigration controls to the immigration controls of the Mauritius colonial government. Importantly, both sets of controls were carried out in the name of protecting 'coolies'. The British presented them as necessary to ensure both that the movement of 'coolie' workers from British India was 'voluntary' and that they were 'freely' selling their labour power. People's free mobility across British imperial territories, such logic held, had to end in order to ensure that British subjects remained 'free' workers. In the process, the coercion inherent in the making and reproduction of a capitalist labour force was obfuscated.

Indeed, precisely to deflect challenges from anti-slavery campaigners, the hallmark of state regulation of Indian 'coolie' labour was the state-authorised labour contract each emigrant was required to sign. ${ }^{24}$ Adding to the new, emergent regime of

23 Mongia, p. 401.

24 Contracts for labour (or service) were, of course, not exclusively used against 'coolie' labour from British India. An 1823 United Kingdom Act which bound workers to their employers through labour contracts described its purpose as 'the better regulations of servants, labourers and work people'. This particular act influenced employment law in Australia (an 1845 Act), Canada (1847), New Zealand (1856) and South Africa (1856). As with contracts of indenture applied to 'coolies', these acts were 
'paper walls', ${ }^{25}$ in 1837 British Indian government regulations laid down specific conditions for the lawful movement of people leaving British India from Calcutta, a main port of the 'coolie' labour trade. The would-be emigrant and his (or less often, her) newly-minted Emigration Agent were required to appear before an officer designated by the colonial British Government of India with a written statement of the terms of their labour contract. Under 'coolie' contracts of indenture, the length of work was to be five years, renewable for further five-year terms. The emigrant was to be returned at the end of his or her service to the port of departure. Each emigrant vessel was required to conform to certain standards of space, diet, etc. and carry a medical officer. In 1837, this scheme was extended to the city of Madras.

The labour contract, often written in English, which 'coolies' signed or, most often, marked with an $\mathrm{X}$ or a fingerprint, allowed the imperial state to make the case that 'coolies' had voluntarily become indentured. Labour contracts thus provided the documentary proof that the 'coolie' system was not a new form of slavery. So central was the contract of indenture to the operation — and legitimisation — of the 'coolie' labour trade that those recruited through it from British India referred to one another as girmit (or 'agreement'). These contracts of indenture further disciplined 'coolie' labour. The contract that bound workers to employers gave the latter much more power to enforce its terms. The imperial state gave employers access to the power of its courts and prisons to judge, punish and discipline those 'coolie' workers accused of not fulfilling their part of the contract. Employers could legally use corporal and other forms of punishment/abuse to enforce the compliance of 'coolies'.

Along with these contracts, which ideologically removed the 'coolie' labour trade from the institution of slavery it was designed to replace, it is also important to note that it was the state's regulations on both immigration and emigration that were central to not only disciplining 'coolie' workers but also ensuring the legitimacy of the labour system under which they were recruited. Without signing contracts of indenture, workers from British India were neither permitted to leave British India nor to enter British Mauritius. Ironically, then, while 'coolies' were portrayed as 'free', the very thing — the contract of indenture - that made them 'coolies' also ensured the unfree labour relationship they worked under.

designed to discipline workers and required their obedience and loyalty to their contracted employer. Infringements of the contract were punishable by the courts and the punishment was often a jail sentence of hard labour. Such statutes remained in effect in England until 1875 when criminal sanctions for premature departure from a contracted place of employment were eliminated (Steinfeld, pp. 115, 160).

25 D S Wyman, Paper Walls: America and the refugee crisis, 1938-1941, University of Massachusetts Press, Amherst, 1968. 
Yet, despite the official rhetoric, it was clear that neither the Mauritius immigration controls nor the emigration controls of the British Indian government protected 'coolie' labourers. Not only were conditions inhumane and dangerous in this new Middle Passage, mortality rates where 'coolies' laboured were very high. 'Coolies,' as Lisa Lowe notes, 'would be shipped on the same vessels that had brought the slaves they were designed to replace; some would fall to disease, die, suffer abuse, and mutiny; [and those] who survived the three-month voyage would encounter coercive, confined conditions upon arrival. ${ }^{26}$ Thus, as soon as knowledge of the new trade in 'coolie' labour became public, anti-slavery campaigns reignited in both the British metropole and in the British colonies, especially in British India. Imperial state claims that 'coolies' were moving voluntarily and were working freely were challenged.

However, it was ending coerced migration - the kind clearly evident in the Atlantic slave trade-which became the focus of these campaigns. A report in the AntiSlavery Reporter stated, that '[i]t should be observed, that, of all the thousands who have hitherto gone to Mauritius, or other colonies, there is no proof afforded that any of them went voluntarily; but, on the contrary, decisive evidence that they were either kidnapped for that purpose, and by force put on board vessels employed in transporting them, or were obtained by the most fraudulent statements. ${ }^{27}$ Their focus on extra-economic coercion and fraud worked to valorise a particular notion of freedom, one defined by the absence of direct force. But while some 'coolie' labourers were undoubtedly pressed into labour, most had been displaced by colonisation and sought to replace what they had lost with new livelihoods. Indeed, tens of millions of people were on the move in search of a means of subsistence. While alluding to the 'helplessness' of the labourers caused by poverty, campaigners avoided discussion over the source of their impoverishment. In particular, the vast majority of anti-slavery campaigners paid scant attention to existing imperialist conditions, precisely the conditions that might make moving preferable to staying. Instead, comments focused on the difficulties caused by their migration. In various issues of the British And Foreign Anti-Slavery Society papers, readers were told: 'At present their families for want of food, are begging from door to door'; 'family is in great distress for maintenance'; 'starving for want of food'; 'their families have taken menial service (become slaves?) for maintenance'; 'and these remarks are not confined to a family here and there, but are applicable to a great extent to all the families left at home by the Coolies on their shipment for Mauritius.'

26 L Lowe, 'The Intimacies of Four Continents' in A L Stoler, Haunted by Empire: Geographies of intimacy in North American history, Duke University Press, Durham and London, 2006, pp. 191-212.

27 British And Foreign Anti-Slavery Society, Emigration from India: The export of coolies, and other labourers, to Mauritius, Cambridge University Press, New York, 1842/2014, p. 47. 
Most campaigners concerned with the 'coolie' labour system argued that the only way to ensure the freedom of workers from India and prevent their abuse was to further reduce their freedom to move. In other words, a worker's freedom from slavery in British India depended on their being immobilised. This immobilisation was presented as a 'protection' for workers, many of whom were dealing with the colonial transformation of the rural economy in India. It was also represented as the emigrants' own preference. To buttress such a conclusion, campaigners argued that mobility itself was anathema to people in India. For example, the Anti-Slavery Reporter of 20 October 1841 argued that the 'population, so far from desiring to emigrate from their native land to distant and foreign parts, are utterly averse to it. They even object to go to distant and unknown sections of their own country. ${ }^{28}$ Again, this flew in the face of actual events on the ground where millions of people were on the move as part of their survival strategies.

Initially, the efforts of anti-slavery campaigners were successful. Convinced that British Indian government regulations were insufficient to protect workers from India, campaigners successfully pressured the government to appoint a special committee to inquire into the issue in 1838. Campaigners were successful in convincing the committee, whose subsequent report stated that, 'We conceive it to be distinctly proved beyond dispute that the Coolies and other natives exported to Mauritius and elsewhere, were, generally speaking, induced to come to Calcutta, by misrepresentation and deceit, practiced upon them by native crimps ${ }^{29} \ldots$ employed by European and Anglo-Indian undertakers and shippers, who were mostly cognizant of these frauds, and who received a very considerable sum per head for each Coolie imported. ${ }^{30}$ Thus, citing fraud and misrepresentation-and not the conditions created by British imperialism — on 29 May 1839, the movement of workers from British India engaged in manual labour was prohibited. Any person effecting their emigration was made liable to the substantial fine of 200 rupees or three months in jail. While a few people moved to Mauritius via the French enclave of Pondicherry in southern India, their movement out of India was effectively halted.

The planters in Mauritius and the Caribbean worked hard to overturn the ban, while the anti-slavery committee worked just as hard to uphold it. Under intense pressure from planters, on 2 December 1842, the governors of the East India Company reversed their earlier decision and the emigration of 'coolies' was again permitted from the ports of Calcutta, Bombay and Madras to Mauritius. However, as a way to avoid comparisons with slavery, newly-minted agents titled Protectors

\footnotetext{
Ibid., p. 46.

29 The term 'crimps' appears to have first been used in the Atlantic slave trade and also in eighteenth century British Navy and Merchant Marine shipping to designate a sub-contractor who secured slaves, seamen or, in this case, 'coolies' for contracted indentured labour.

30 British And Foreign Anti-Slavery Society, p. 49.
} 
of Emigrants were appointed at each departure point. Likewise, an office of the Protector of Immigrants in Mauritius was established. That year, almost 35,000 people were shipped as indentured 'coolies' from India to Mauritius. The 'coolie' trade expanded rapidly, as did sugar production on Mauritius. By the mid-1850s, sugar production surpassed 100,000 tons a year. ${ }^{31}$ A ship transporting 'coolie' labourers arrived every few days in Mauritius and such a large number of 'coolie' labourers caused a backlog in processing. Between 1834 and 1867, it is estimated that approximately 366,000 indentured labourers from India had entered Mauritius. The 'coolie' trade soon expanded to become part of the global supply chain of workers for the expanding British Empire. By 1844, 'coolies' were shipped to British colonies in the West Indies, including Jamaica, Trinidad and Demerara. Eventually, 'coolie' labourers from Asia were transported throughout the British Empire and, to a lesser extent, to the French, German, Dutch, Danish, Spanish, Portuguese, Belgian and US colonies. ${ }^{32}$

Early imperial-state regulation of the movement of labour represented as 'free' thus took place in the historical conjuncture of the end of slavery and investors' continued need for a cheapened and legally disciplined workforce. While campaigners were unsuccessful in shutting down the 'coolie' labour trade, an outcome which did not provide for new livelihoods for the people rendered immobile, they did contribute enormously to the portrayal of workers engaged in migration as simple, ignorant and vulnerable and thus in need of the protection of both contracts and controls to limit their mobility. In this sense, the first effort to exert state sovereignty over the in-migration of persons into state territories took place in relation to limiting the mobility of workers, all in the guise of protecting them.

\section{The Logics of Constraining Free Mobility}

While the contemporary figure of the immigrant — the one that current campaigns to end 'modern-day slavery' wish to protect—was initiated by the British imperial state, it is under the nation-state's 'logic of constraint' that the category of immigrant was cemented as a crucial state and labour market category. ${ }^{33}$ It is after the rise of nationalism in the eighteenth century as evident in the French Revolution - and the formation of the world's first nation states in the late nineteenth and early twentieth century — when pressure to enact more and more regulations and restrictions intensified. The first national controls on immigration began in the Americas, where former colonies had successfully transformed

\footnotetext{
Allen, p. 12.

Potts, p. 67.

Mongia, p. 403.
} 
themselves into 'self-governing' states, which by the late nineteenth century had nationalised their sovereignty. Peru was the first in 1853, followed in quick succession by other states across the Americas. By the period between the two world wars, each state in the Americas had nationalised its sovereignty. Each of these new nation states announced their newfound national sovereignty by enacting racist immigration controls, often with a highly gendered component to them. With the institutionalisation of the idea that 'nations' were units of homogenous so-called races, states became intent on regulating and restricting the movement of negatively racialised people into their claimed territories and in regulating the sexual 'respectability' of the women they allowed to enter.

From the start, racist immigration controls were intended to keep 'undesirables' out of state spaces undergoing the process of nationalisation. Although negatively racialised people were unwanted as co-members of the nation, their labour power was, nonetheless, very much needed. Immigration regulations and restrictions, thus, not only worked to deny them entry (which they certainly did at particular moments in various national histories) but worked to place those who did get in into new state categories of 'immigrant' that ensured that their labour power would be regulated as 'immigrant labour' within the state.

As with the first British imperial regulations and restrictions on the free mobility of co-imperial subjects from British India, many of the first national controls on immigration often concerned those who were recruited as 'coolies'. For example, the first constraints against people's free entry to the United States- the 1875 Page Act — expressly barred the entry of two categories of persons: 'coolies' from China and women deemed to be 'prostitutes'. Not dissimilar to anti-slavery campaigns arguing to limit the mobility of people in British India, US trade unions, whose membership was largely limited to white male workers, came to represent 'coolie' labour as a 'relic of slavery' and sought to limit their entry. ${ }^{34}$

By the late nineteenth century, white male workers had largely escaped the unfree employment relations established by various Masters and Servants Acts. In winning their 'freedom' against the continued unfreedom of Others, they insisted on the exclusion of all those who were still labouring under unfree employment relations. As I have discussed elsewhere, ${ }^{35}$ the process by which free labour was normalised was both relational and highly ideological as it was founded in the emergence of national, liberal styles of governance with their racialised and gendered criteria for national subjectivities. Freedom and unfreedom were constituted through the establishment of political hierarchies shaped by now-national immigration policies.

\footnotetext{
34 Lowe, p. 202.

35 N Sharma, Home Economics: Nationalism and the making of 'migrant workers' in Canada, University of Toronto Press, Toronto, 2006.
} 


\section{Conclusion}

Regulations against 'coolies' were the first contemporary inter-statal regulations on immigration. It is when the 'coolie' recruitment system replaced the slave labour system that the figure of the immigrant came into being. The immigrant was the person whose movement across space was regulated, initially in the early nineteenth century by the British imperial state eager to facilitate and legitimate the availability of a highly disciplined and therefore cheapened workforce of 'coolies' and, by the end of the nineteenth century, by nationalising states (such as the United States) intent on legitimising a racialised view of the now-national political community while simultaneously cheapening a negatively racialised workforce. The regulation of human movement entailing something we can term a system of migration came into being with the regulation of workers largely from various parts of Asia, the vast majority of whom were recruited through the 'coolie' labour system.

The nation-state's 'monopoly of the legitimate means of movement' did not target all people on the move but only those grouped together through prevailing ideas of race as well as normative ideas of gender (e.g. restrictions on the entry of 'prostitutes'). ${ }^{36}$ The migrant was, thus, from the outset, a negatively racialised and gendered figure. That this figure was deemed undesirable and 'unassimilable' demonstrates the centrality of ideas of nation-ness to the racialisation and gendering of immigration controls. Crucially, then, it was through the regulation of the international mobility of 'undesirables' that states nationalised their sovereignty and the subjectivities of those who believed they belonged to the nation that such states purported to rule for. Neither regulations on emigration nor restrictions on immigration were meant to stop the movement of workers, however, but only to ensure that their labour was sufficiently disciplined. State regulations and restrictions were not only about numbers but also about the rights accorded by the state to various groups of immigrant workers. Importantly, the regulation of migration arose alongside the growing nationalisation of states from the late nineteenth/ early twentieth and into the twenty-first century. In the process, ideas about mobility and people's movements changed profoundly.

Obscured in efforts to regulate and restrict human mobility was, as Ellen Meiskins Wood cogently acknowledges, the fact that 'the distinctive and dominant characteristic of the capitalist market is not opportunity or choice but, on the contrary, compulsion. Material life and social reproduction in capitalism are universally mediated by the market, so that all individuals must in one way or another enter into market relations in order to gain access to the means of life. ${ }^{37}$ The immobilisation of

\footnotetext{
36 J Torpey, The Invention of the Passport: Surveillance, citizenship, and the state, Cambridge University Press, Cambridge, 2000.

37 E M Wood, The Origin of Capitalism: A longer view, Verso, London, 2002, p. 7.
} 
persons seeking a livelihood, all the while maintaining, indeed intensifying capitalist market practices that entailed expropriation and exploitation was, and remains, the height of hypocrisy.

Today, we have a globalised system of immigration controls in which it is nearly impossible to move freely across now-nationalised borders, particularly for those left with little but their labour power to sell in the capitalist marketplace. As François Crépeau has well noted, 'We have established all the barriers we could think of to prevent refugees [and other categories of immigrants] from coming: imposition of visas for all refugee-producing countries, carrier sanctions, "short stop operations", training of airport or border police personnel, lists of "safe third countries", lists of "safe countries of origin", readmission agreements with neighbouring countries forming a "buffer zone", immigration intelligence sharing, reinforced border controls, armed interventions on the high seas... [] military intervention....38 and, as recently announced, even efforts by the European Union to launch attacks against ships used to carry people attempting to move from Northern Africa to Europe.$^{39}$ Notably, this last-but also many other-border control measures have been rationalised as efforts to protect migrants and to 'end trafficking'. ${ }^{40}$ In this, much was learnt from the earliest imperial efforts to regulate and restrict free human mobility. Now, as then, the trope of 'rescue' is a powerful one in legitimating even murderous actions against those rendered as immigrants.

Yet, the greatest danger to people trying to cross national borders is the immigration policies and policing of nation states. Moreover, the categories that nation states slot most migrating people into_- 'illegal' or 'temporary foreign worker' being two of the largest - are the greatest threats to their liberty. Being categorised as 'illegal' or 'temporary' is what entraps a growing number of people on the move

38 F Crépeau, 'The Fight Against Migrant Smuggling: Migration containment over refugee protection' in J van Selm, K Kamanga, J Morrison, A Nadig, S Spoljar-Vrzina and L van Willigen, The Refugee Convention at Fifty. A view from forced migration studies, Lexington Books, Lanham, 2003, pp. 173-185, p. 174.

39 Moreover, as Thierry Tardy notes, the EU Council established 'Operation Sophia' on 18 May 2015. 'The operation's mandate,' he documents, 'is to contribute to the "disruption of the business model of human smuggling and trafficking networks in the Southern Central Mediterranean" by "efforts to identify, capture and dispose of vessels used or suspected of being used by smugglers". The operation focuses on smugglers rather than on the rescue of the migrants themselves.' See: T Tardy, Operation Sophia. Tackling the refugee crisis with military means, European Union Institute for Security Studies, 2015.

40 I Traynor, 'EU draws up plans for military attacks on Libya targets to stop migrant boats', The Guardian, 10 May 2015, retrieved 10 May 2015, http:// www.theguardian.com/world/2015/may/10/eu-considers-military-attacks-ontargets-in-libya-to-stop-migrant-boats?CMP=share_btn_fb. 
into substandard working and living conditions while severely limiting their rights and mobility. Thus, national immigration policies legislate the conditions that make some people 'cheap' or even 'disposable'. Quite simply put: without national immigration policies, there would be no such group we know as immigrants who could be subordinated, scapegoated and abused—or rescued.

We learn about none of these real-life dangers and exploitations from the ever-multiplying accounts of 'human trafficking' and 'modern-day slavery', however. The discursive state practice of ending trafficking or 'modern-day slavery' is wholly reliant on the acceptance of the legitimacy of national immigration regimes and their lack of concern with the gross disparities and exploitation organised by capitalist social relations, relations of which human mobility has always been and remains an integral part. Anti-trafficking policies do a great disservice to migrating people, especially the most vulnerable, and do much to divert our attention away from the practices of nation states and employers and to channel our energies in support of a law-and-order agenda of 'getting tough' on 'traffickers'—even to the extent of attacking them militarily.

In this way, anti-trafficking measures are ideological: they render the plethora of immigration and border controls as unproblematic and attempt to place them outside of the bounds of politics. The reasons why it is so difficult and increasingly dangerous for people to move safely or to live securely in the places they move to is brushed aside while nation states rush to criminalise 'traffickers' and (largely) 'send home' (i.e. deport) 'victims of trafficking'. Today, as in past discourses of 'protecting coolies', the discursive practices of 'anti-trafficking' spectacularly fail the needs of people by failing to call for their free mobility across space and their freedom within nationalised labour markets.

Nandita Sharma is an Associate Professor in the Department of Sociology at the University of Hawaii at Manoa (Honolulu) and the Director of its International Cultural Studies Program. Her research interests address themes of human migration, migrant labour, national state power, ideologies of racism and nationalism, processes of identification and self-understanding, and social movements for justice. She has numerous publications in journals and edited volumes and is the author of Home Economics: Nationalism and the making of 'migrant workers' in Canada. Email: nsharma@hawaii.edu 


\title{
'Bound Coolies' and Other Indentured Workers in the Caribbean: Implications for debates about human trafficking and modern slavery
}

Kamala Kempadoo

\begin{abstract}
Under systems of indenture in the Caribbean, Europeans such as Irish, Scots and Portuguese, as well as Asians, primarily Indians, Chinese and Indonesians, were recruited, often under false pretences, and transported to the 'New World', where they were bound to an employer and the plantation in a state of interlocking incarceration'. Indentureship not only preceded, co-existed with, and survived slavery in the Caribbean, but was distinct in law and in practice from slavery. This article argues that the conditions of Caribbean indenture can be seen to be much more analogous to those represented in contemporary discussions about human trafficking and 'modern slavery' than those of slavery. Caribbean histories of indenture, it is proposed, can provide more appropriate conceptual tools for thinking about unfree labour today — whether state or privately sponsored — than the concept of slavery, given the parallels between this past migrant labour system in the Caribbean and those we witness and identify today as 'modern slavery' or human trafficking. This article thus urges a move away from the conflation of slavery and human trafficking with all forced, bonded and migrant labour, as is commonly the case, and for greater attention for historical evidence.
\end{abstract}

Keywords: indenture, transatlantic slavery, modern slavery, human trafficking, Caribbean

Please cite this article as: K Kempadoo, “Bound Coolies” and Other Indentured Workers in the Caribbean: Implications for debates about human trafficking and modern slavery', Anti-Trafficking Review, issue 9, 2017, pp. 48-63, www.antitraffickingreview.org

This is an open-access article distributed under the terms of the Creative Commons Attribution License (CC-BY). Under the CC-BY license, the public is free to share, adapt, and make commercial use of the work. Users must always give proper attribution to the authors and the Anti-Trafficking Review. 


\section{Introduction}

Practically, an immigrant is in the hands of the employer to whom he is bound. He cannot leave him; he cannot live without work; he can only get such work and on such terms as the employer chooses to set him; and all those necessities are enforced, not only by the inevitable influence of his isolated and dependent position, but by the terrors of imprisonment and the prospect of losing both labour and wages (Beaumont 1871). ${ }^{1}$

When it is remembered that the victim of the system-I can call them by no other name- - are generally simple, ignorant, illiterate, resourceless people belonging to the poorest class of this country and that they are induced to enter-or it would be more correct to say they are entrapped into entering-into these agreements by the unscrupulous representations of wily professional recruiters who are paid so much a head for the labour they supply and whose interest in them ceases the moment they are handed to the emigration agents, no fair minded man will, I think, hesitate to say the system is a monstrous system, iniquitous in itself, based on fraud and maintained by force (Gokhale 1912). ${ }^{2}$

Indian and Chinese indenture in the nineteenth century, as described by observers such as Gokhale and Beaumont, lend themselves to a reflection on that history for discussions about human trafficking today, given the striking similarities in conditions that are presented about both. The resurgence of the claim that Irish indentures were 'slaves' in the history of the Americas ${ }^{3}$ urges us to consider the broader question of how indentureship can be understood as 'modern slavery'.

1 J Beaumont, The New Slavery: An account of the Indian and Chinese immigrants in British Guiana, W Ridgway, London, 1871, republished by The Caribbean Press, 2011.

2 Gopal Krishna Gokhale's speech calling for suspension of Indian indentured emigration: Government of India, Legislative Department, Proceedings of the Council of Government, 1912.

3 See for example: L Hogan, L McAtackney and M C Reilly, 'The Unfree Irish in the Caribbean were Indentured Servants, Not Slaves', The Journal.ie, 6 October 2015, retrieved 10 April 2017, http://www.thejournal.ie/readme/irish-slaves-myth2369653-Oct2015. 
Given that Irish, Chinese and Indian indenture and the enslavement of Africans were important to the making of the Caribbean and have long been discussed by Caribbeanists, it seems appropriate to delve into the region's history and scholarship to think through such questions. I propose here that the simultaneous and serial histories of slavery and indentureship in the Caribbean, alongside centuries of observations, accounts, and analyses comparing the two systems, provide us with tools for a rethinking of current discourses of human trafficking and 'modern slavery'.

The questions I seek to engage here are not about which labour systemindentureship or slavery — was the more monstrous, for both were violent, coercive and inhumane. I am also not interested in contributing to scholarship that argues for a hierarchisation of oppression. Rather, I am preoccupied with questions about how histories of slavery and bound labour ${ }^{4}$ in areas of the world such as the Caribbean can be seen as 'parallel lives and intertwined belongings', which produce different knowledge and understandings, ${ }^{5}$ and which in turn could influence current thinking about human trafficking and 'modern slavery'. Moreover, as a critical sociologist, inspired by a historical materialist reading of the social and political, this paper does not engage with debates about the 'use and abuse' of history. Rather, it is an effort to present an alternative to those discourses on 'modern slavery' and human trafficking that lack a reflexivity about slavery in the past, and which currently dominate public and policy interpretations of forced and migrant labour. ${ }^{6}$

4 I use the term 'bound labour' to point generally to the practice of indenture in the Caribbean as well as contemporary migrant labour systems—state and privately sponsored-that recruit people often through fraudulent means, tie a labourer to an employer or sponsor, require them to work at a specific job for a period of time, and involve some form of financial indebtedness. This may or may not be similar to the concepts of 'bonded', 'debt-bonded' or 'forced labour'. It is noted, however, that these and other such terms all present definitional problems, generate endless debate amongst labour historians, and are often used interchangeably in discussions about human trafficking and modern slavery.

5 K Nimako, 'Conceptual Clarity Please! On the uses and abuses of the concepts of "slave" and "trade" in the study of the transatlantic slave trade and slavery' in M Araújo and S Rodríguez Maeso, Eurocentrism, Racism and Knowledge, Palgrave Macmillan, 2015, p. 189.

6 This paper was first presented at Durham University in May 2017, and while it has greatly benefitted from discussion with Siobhan McGrath, David Lambert, and Richard Huzzy, as well as from feedback from two anonymous reviewers and the Anti-Trafficking Review editors, it remains a work in progress. 


\section{Caribbean Indentureship}

Caribbeanist historians, sociologists, anthropologists, storytellers, novelists, poets and the like, tend to agree that indentureship was a labour system that pre-dated, co-existed with, and survived slavery, and was organised with a considerable level of fraud and violence by colonial governments to enable farm and plantation owners access to and control of a large pool of low-cost wage labourers for the agri-industry. Indentureship in the Caribbean was integral to the globalisation of capitalism from the fifteenth century onwards. The drive to accumulate capital not only interfered with other modes of production/ways of life and produced social and economic dislocations and political conflicts, but moved labour from those areas that it impoverished and disrupted to new hubs of production, such as plantations in the 'New World'. The Caribbean system of indenture relied on the recruitment, often under false pretences, of dispossessed and marginalised people (mostly young adult men) from Europe and Asia, and contractually binding them to a fixed term of work for a single employer in the British, Dutch, Danish, Spanish and French colonies in exchange for transportation to (and sometimes from) the colonies, subsistence wages and in some instances, land. Indenture contracts varied between one and fourteen years, with possibilities or requirements for re-indenture after the initial contract. The indentured were shipped to the Caribbean and confined to a plantation or estate where they lived and worked under conditions comparable to those for Africans under slavery. They had no choice in employer, could not change employers or buy themselves out of, or negotiate their contract, nor could they move freely without the consent of their employers. Planters in collusion with colonial governments often managed to maintain them in states of indenture or dependency through creating economic conditions that demanded or required re-indenture after the initial contract. The indentured were, in Guyanese Indian vernacular, 'bung coolies'-bound to employer and the plantation-in a pattern of 'interlocking incarceration'?

While most attention goes to the system that followed the abolition of slavery by the British in 1834, indentureship also occurred both before and during the period of slavery. Impoverished, destitute or imprisoned white European men and women, as well as children, made up some of the first cohorts of labourers from the late 1620 s to early 1700 s, the majority of whom were indentured to tobacco and cotton farms in the Caribbean. Numbers are hard to come by, but estimates are that prior to 1660 around 190,000 whites arrived in the English colonies in the Caribbean, such as Barbados, St. Kitts and Nevis, Montserrat, Antigua and

B V Lal, 'The Odyssey of Indenture: Fragmentation and reconstitution in the Indian diaspora', Diaspora, vol. 5, no. 2, 1996, p. 174. 
Jamaica. ${ }^{8}$ Barbados, for example, received a large number of Irish indentures and some Scots, English and Welsh who, prior to the late 1640s, are said to have mostly left for the Caribbean 'willingly', in search of a better life. Some were under contract 'to work for their master for an agreed-upon period (usually between three and seven years) in exchange for the cost of their passage, clothing, provisions while in service, and the promise of between two and ten acres of land upon the completion of their term of indenture'. Many thousands of others, including children, arrived without contracts. They were joined by vagrants, those considered felons and criminals who were exiled to the island, and political prisoners following conflicts such as the 1649 Cromwell invasion of Ireland, which led to several thousand Irish and others being 'Barbadosed'. ${ }^{10}$ Women were also rounded up and taken off the streets of London and shipped to the colonies. All were pressed into indenture as agricultural labourers, often working alongside enslaved Africans. ${ }^{11}$ With the expansion of the land-gobbling sugar plantation and the turn to Africa for a seemingly endless and more controlled labour supply, the promise of land as well as future work for the former indentured evaporated, leaving a mostly 'un(der)employed, poor and propertyless population'. ${ }^{12}$ White, landless, formerly indentured workers sought to re-indenture themselves, tried to migrate elsewhere, or eked out a living in the marginal spaces. ${ }^{13}$

8 M Binasco, 'The Activity of Irish Priests in the West Indies, 1638-1669', Irish Migration Studies in Latin America, vol. 7, no. 4, 2011, retrieved 10 April 2017, http:/ /www.irlandeses.org/imsla2011_7_04_10_Matteo_Binasco.htm.

9 M C Reilly, 'The Irish in Barbados: Labour, landscape and legacy' in A Donnell, M McGarrity and E O'Callaghan (eds.), Caribbean Irish Connections: Interdisciplinary perspectives, University of the West Indies Press, Kingston, 2015, p. 49.

10 J Sheppard, 'Indentured Servants of Barbados', Bim, vol. 15, no. 57, 1974, pp. 4155; S O'Callaghan, To Hell or Barbados? The ethnic cleansing of Ireland, Brandon, Dublin, 2001; J S Handler and M C Reilly, 'Contesting "White Slavery" in the Caribbean: Enslaved Africans and European indentured servants in seventeenth-century Barbados', New West Indian Guide, vol. 91, issue 1-21, 2017, pp 30-55.

11 Reilly; H Beckles, White Servitude and Black Slavery in Barbados, 1627-1715, University of Tennessee Press, Knoxville, 1989.

12 Reilly, p. 53. See also: D Lambert, White Creole Culture, Politics and Identity during the Age of Abolition, Cambridge University Press, Cambridge, 2005.

13 The ethnic group still known today as the 'Redlegs' - the poor whites of Barbados — are the legacy of this history. See also: H O'Brien, 'The Final Fortress: The Redlegs and Bajan-Irish Abjection' in A Donnell, M McGarrity and E O'Callaghan (eds.), Caribbean Irish Connections: Interdisciplinary perspectives, University of the West Indies Press, Kingston, 2015, pp. 174-186. 
Later cohorts of indentured workers arrived in the Caribbean from 1834, after the emancipation of Africans from slavery under the British, continuing well into the twentieth century, consisting primarily of Indians, Chinese and Indonesians ('Javanese'), with smaller numbers from Britain, Malta, France, Germany, and Madeira and the Azores ('Portuguese'). Some formerly enslaved Africans already in the Caribbean as well as Africans transported directly from Africa, were also indentured. Around half a million Indian workers replaced enslaved Africans on Caribbean plantations in this period with the majority in Guyana, Trinidad and Suriname, others in Jamaica, Guadeloupe, Grenada and French Guiana. ${ }^{14}$ Around 120,000 Chinese were transported to Cuba, and between 1853 and 1884 about 18,000 to British colonies, especially Guyana. ${ }^{15}$ Surinamese history captures the extent and diverse origins of the indentured population in the Caribbean from the nineteenth century on. The Dutch colony drew first on labour from China and Madeira, then from Dutch colonies in Indonesia and British colonies in the Caribbean, and from 1873 to 1916 from India. ${ }^{16}$ The transportation of indentured labourers from Indonesia continued until 1939.

Around the region, indentureship and slavery were complexly intertwined. The indentured all started out as agricultural workers and domestic servants, sometimes working alongside enslaved Africans. Yet some, such as whites and Chinese, were encouraged to take up semi-skilled, artisanal, or shopkeeping positions, with some whites securing racial privilege through the 'public and psychological' reward of whiteness ${ }^{17}$ taking up appointments as lowly managers and overseers of the enslaved. Some former enslaved Africans, in seeking to survive after being freed from slavery, opted for or were driven into indentureship, often moving to colonies where the agri-industry was then expanding (particularly the Guyanas) ${ }^{18}$

$14 \mathrm{~K}$ O Laurence, A Question of Labour: Indentured immigration into Trinidad and Guyana 1875-1917, Ian Randle Press, Kingston, 1994; L Roopnarine, 'A Critique of East Indian Indentured Historiography in the Caribbean', Labour History, vol. 55 no. 3, 2014, pp. 389-401.

15 M Turner, 'Chinese Contract Labor in Cuba, 1847-1874' in H Beckles and V Shepherd (eds.), Caribbean Freedom: Economy and society from Emancipation to the present, Ian Randle Press, Kingston, 1993, pp. 132-140; W Look Lai, Indentured Labor, Caribbean Sugar: Chinese and Indian migrants to the British West Indies, 1938-1918, Johns Hopkins University Press, Baltimore, 1993.

16 R Sewradj-Debipersad, Emancipatie van Hindoestaanse Vrouwen: Een beschrijving van veranderingen in het leven van Hindoestaanse vrounen in Suriname vanaf 1873 (The Emancipation of Hindustani Women: A description of changes in the lives of Hindustani women in Suriname from 1873), CERDES, Paramaribo, n.d.

17 Lambert, p.36.

18 See: Laurence 1994; M Schuller, 'African Immigration to French Guiana', Journal of African Studies Association of the West Indies, no. 4, 1971, pp. 62-73. 
In recalling the voyage of the Cinq-Freres with Africans from Sierra Leone to French Guiana in 1854, Monica Schuller observes that, 'Three shipping companies recruited indentured workers to French Guiana... the first two were for the voluntary engagement of free Africans, while the other involved the purchase of slaves followed by a declaration of their freedom, and their immediate enrolment as contract labour for French Guiana. ${ }^{19}$ Celine Flory adds to this, noting that the French government established a 'repurchasing' programme_rachat — whereby private merchants could purchase captive Africans and force them into a ten-year indenture contract in French Caribbean colonies. ${ }^{20}$ Such a switch from slavery to indenture also occurred when ships bound for Cuba and Brazil, carrying enslaved Africans in contravention to the European agreements of the time, were intercepted by British ships. The Africans were freed from slavery and, on arrival in the Caribbean, sold as indentured workers. ${ }^{21}$ Caribbean history is thus marked by the overlapping of two distinct labour regimes for over three centuries, with people sometimes moving between the two, experiencing both, and with planters managing both, at times simultaneously.

\section{Indentureship as Slavery?}

Caribbean indentureship — both the early and later forms — has often been compared to and described as slavery. In 1667, for example, the indentured were being described as 'poor men that are just permitted to live, and a very great part Irish, derided by the Negroes, and branded with the epithet "white slaves"' 22 , or as sharing a common sufferance and a common grievance with enslaved Africans. ${ }^{23}$ In 1835 in a petition to the Governor of Trinidad, Portuguese indentures wrote:

19 Schuller, p. 67.

20 C Flory, 'Between Indenture and Slavery? African indentured laborers in the French West Indies (1852-1862)', Francophone Africa: Critical perspectives, University of Portsmouth, 8 December 2016, retrieved 7 July 2017, http://francophone.port.ac.uk/ $? \mathrm{p}=1223$. In both Schuller's and Flory's work on the French Caribbean, indenture is synonymous with engagé labour.

21 E Williams, The History of the People of Trinidad and Tobago, Andre Deutsch, London, 1963.

22 Anonymous, quoted in Reilly, p. 51.

23 A Donnell, M McGarrity and E O'Callaghan, 'Introduction: Caribbean-Irish Connections: Creolizing histories, historicizing imaginings' in A Donnell, M McGarrity and E O'Callaghan (eds.), Caribbean Irish Connections, pp. 1-14. 
That with many of their countrymen, they were induced by certain evil disposed persons, under false pretenses, to quit their native country, Fayal, to become agricultural labourers in this Colony. Of the whole number thus cajoled, one third only are still in existence. The rest have fallen victims to the unhealthiness of the climate or the cruelties of the slavery system to which we, equally with the unfortunate blacks have been subjected. ...Men, women and children have suffered the greatest misery and oppression on several estates where they have been forced to work far beyond their strength by coercion of the whip, without proper shelter at night or adequate food during the day. ${ }^{24}$

Following the abolition of slavery, it was not uncommon for indentureship to be labelled 'the new slavery', especially by those agitating for the abolition of the system, with figures such as the former Chief Justice in British Guiana, Joseph Beaumont, publishing his observations in Britain under titles such as The New Slavery: An Account of the Indian and Chinese Immigrants in British Guiana. According to British abolitionist George Thompson in an address to the House of Commons in the 1880s about indentureship, 'The system of emigration has been false, and to attempt to carry it out extensively would only be to create a new slave trade under the false colours and a modified description. ${ }^{25}$ Similarly, a later trend in Caribbean historiography has been identified as 'neo-slave scholarship', in which indentured Indians in particular have been categorised and described in similar ways to enslaved Africans - as victims, forced and broken, and subject to intense violence, with little agency or ability to resist. ${ }^{26}$ Likewise, it is argued that the recent resurgence of the white slavery narrative in the Americas appropriates a history of suffering and trauma, and stresses 'a sense of shared victimization' with enslaved Africans. ${ }^{27}$

A large part of the claims of indenture-as-slavery lies in the material conditions of indentureship and de facto experiences of the enslaved and the indentured. Richard Ligon, in writing about his stay in Barbados from 1647 to 1650, remarked, if the masters be cruel, the servants have very wearisome and miserable lives...I have seen cruelty there done to Servants, as I did not think one Christian could

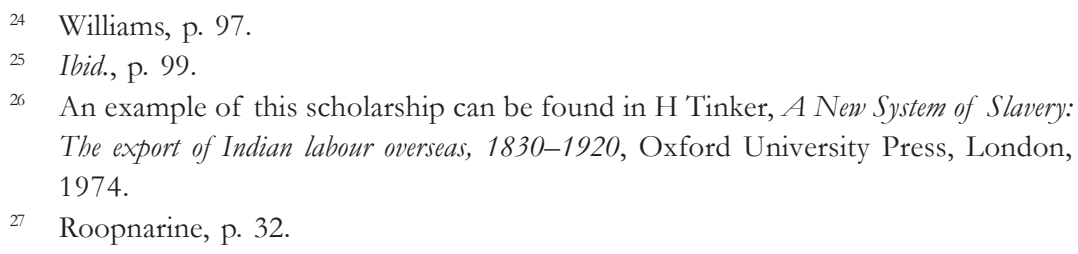


ANTI-TRAFFICKING REVIEW 9 (2017): 48-63

have done to another.' ${ }^{28}$ About the shipping of Chinese to the Caribbean, Mary

Turner notes:

The ships employed in the trade ... were prepared like the slave ships with gratings over the holds to allow only one person on deck at a time: small cannon, ready loaded, guarded the mouth of the hatches and the steam ships had neat contrivances for letting steam into the hold in case of real trouble ... only the chains were missing. Water shortages, disease and mutinies characterised the voyages... the sailors called them death voyages. ${ }^{29}$

On arrival in Cuba, Chinese indentures were 'subjected to the same discipline as slaves'.$^{30}$ Others have commented on the cultural similarities to the construction of the category 'slave', through a process of dehumanisation and violence. The British made 'coolies', Gaiutra Bahadur writes:

the system took gardeners, palanquin bearers, gold-smiths, cow-minders, leather-makers, boatmen, soldiers, and priests with centuries-old identities based on religion, kin and occupation and turned them all in an indistinguishable, degraded mass of plantation laborers without caste and family... Like the slaves before them, they were an entirely new people, forged by suffering, created through destruction. $^{31}$

Slavery and indenture appear to share many dimensions in such first- and secondhand accounts, and slavery has been and continues to be evoked in ways to speak about the cruelties, coercions, and highly exploitative character of the indentureship system. Such attempts to describe Caribbean indentureship as a new form of slavery, or to equate it with slavery-like conditions, are analogous to the twenty-first century efforts to make forms of migrant labour coeval with human trafficking. It also signals the ease with which slavery worked then, as it does today, as a metaphor for a lack of freedom. However, despite similarities in some conditions and experiences of enslavement and indenture and the violence of both labour systems in the Caribbean, the two are widely recognised by scholars and writers alike to be quite distinct from each other-distinctions that have resonance for discussions about 'modern slavery' and human trafficking.

28 Quoted in Reilly, p. 51.

29 Turner, p.136.

${ }^{30} \quad$ Ibid.

31 G Bahadur, Coolie Woman: The odyssey of indenture, University of Chicago Press, 2014, p. 63. 


\section{Modern Slavery and Human Trafficking as Indenture?}

A most obvious distinction is that the indentured in the Caribbean were for the most part contracted, and it was their labour that was sold and traded as a commodity through the indenture contract that tied them to the employer. They were not, as enslaved Africans were, legally defined as property, chattel, or non-human, not excluded from property rights, nor were their 'owners' compensated for the loss of property at the point of their emancipation. Morally and legally the indentured were defined as human persons — albeit, in Mill's term, sub-persons ${ }^{32}$ — who could make claims to legal rights both as citizens of their home country and under indenture laws in the colonies, ${ }^{33}$ and could own property. The premise of a contractde facto or de jure — and the claim to rights that were experienced by the indentured in the Caribbean, echo today throughout discussions about human trafficking and 'modern slavery', where it is also widely acknowledged that the majority of 'trafficked victims' or 'slaves' are defined as being bound to specific types and terms of work, often through a debt ${ }^{34}$ retain basic citizenship rights in their countries of origin and can make claims to a range of human rights, even while they may be denied rights as (im)migrants at the new sites of work.

Perhaps as importantly for a comparison with slavery discourses, is that indenture for the most part rested upon 'choice' - that is, impoverished, destitute, dispossessed people were compelled to find some form of subsistence and even though were 'lured' to the 'New World' by recruiters with promises of 'a new life' and prosperity without usually knowing about the cost of living in the colonies or the conditions of work, went voluntarily. ${ }^{35}$ The indentured, as is recounted for the Irish as well as later groups, had a choice between staying in places where conflict or famine ruled, or going along with a recruiter and accepting a contract to work for a fixed term overseas, at times being enticed by 'massive propaganda campaigns' about the opportunities in the Caribbean. ${ }^{36}$ Bahadur observes about the recruitment of Indian 'coolies':

32 C V Mills, 'The Political Economy of Personhood', Beyond Trafficking and Slavery, 16 June 2015, retrieved 27 April 2017, https://www.opendemocracy.net/ beyondslavery/charles-w-mills/political-economy-of-personhood.

33 Handler and Reilly; Roopnarine.

34 K Bales, Disposable People: New slavery in the global economy, University of California Press, Berkeley/Los Angeles, 1999; J Quirk, 'Trafficked into Slavery', Journal of Human Rights, vol. 6, no. 2, 2007, pp. 181-207.

35 Lal, p. 174.

36 Sheppard. 
ANTI-TRAFFICKING REVIEW 9 (2017): 48-63

Recruiters lived in the local imagination as schemers, liars, even kidnappers. According to widespread belief, they did not inform. They misinformed. They gave recruits the false impression that they could return home from their jobs for the weekend: they promised work as easy as sifting sugar; and they exaggerated the gains to be had, inflating wages and conjuring lands of milk, honey and gold. In coolie folk songs, the recruiter is a cursed, vilified figure. ${ }^{37}$

In such a process, it is argued, one can hardly speak of free choice, but instead a choice determined by need-a circumscribed agency. ${ }^{38}$ The 'choice' for indenture rested preponderantly on a desire to find a better life, often to escape violencefamily, spousal, and other—or starvation. Thus, as Dale Bisnauth concludes, even though the fear, in the case of Indians, of crossing 'the Black Waters' and hence to become outcasted, was very strong, 'the stress of circumstances' proved for some to be stronger. ${ }^{39}$ As with so-called modern slaves and trafficked persons today, they were, in Jo Doezema's words, 'forced to choose'. ${ }^{40}$ Enslaved Africans, on the other hand, had no semblance of choice at any point in the process. They were kidnapped, stolen from their homes and villages, manacled, and taken in chains from Africa to the Americas. There is little scholarly or other disagreement about their forced departure from villages in Africa, or about the brutal conditions in the baracoons and forts of West Africa, on the ships on the middle passage, or on the auction block and sugar plantations in the 'New World'. Enslavement did not depend on Africans being pushed by famine, landlessness, domestic violence, or other miserable conditions - they were captives, denied any form of decision-making or agency in the process of being made a slave.

Historiography thus identifies the 'root causes' for indenture as similar to those identified for trafficked persons and the 'modern slave'. The poverty, food shortages, landlessness, family circumstances, domestic violence, war or religious persecution, or a search for security and safety that propelled people into indenture, occurred alongside but was not the same as the history of the capture and enslavement of Africans. However, both systems shared a global context of the

37 Bahadur, p. 38

38 Sewradj-Debipersad. See also: Bahadur.

39 D Bisnauth, The Settlement of Indians in Guyana 1890-1930, Peepal Tree Press, London, 2000, p. 41; see also: Laurence.

40 J Doezema, 'Forced to Choose: Beyond the voluntary v. forced prostitution dichotomy' in K Kempadoo and J Doezema, Global Sex Workers: Rights, resistance and redefinition, Routledge, New York, 1998, pp. 34-50. 
expansion of capitalist production and industries and capital's constant search for cheap labour and services, as well as the space of the plantations in the 'New World'. And it is the parallel history of indenture, with its tangle of dislocation, survival strategies, fraud, demands of capital, and hopes for a better life, that led many people to enter into formal and informal agreements with recruiters and employers. Contemporary migrant labour systems, such as work programmes in Canada that rely on agricultural labour from Jamaica and Mexico, domestic labour from the Philippines, and sexual labour from Latin America and post-socialist states in Europe, continue to manifest problems similar to those encountered by indentured workers in Caribbean history: recruitment under false pretences, repayment through labour for an overseas passage, low wages, agreements that tie them to one employer, and poor working and living conditions at the new site of employment. And while human trafficking is usually claimed to operate underground, the state continues today to regulate labour and capital, profiting from arrangements that enable conditions of unfreedom. ${ }^{41}$ In this way, the role of the state in creating the conditions for trafficking resonates with the regulation of indenture by colonial governments.

Indenture was constructed as temporary and return home was promised and therefore sometimes possible. Between $20-25 \%$ of Asians are believed to have been repatriated after indenture in the Caribbean. Some were forced into another period of indenture in order to qualify for their passage home. Many of the migrant workers did not or would not return to their natal land once their indenture had ended, and having no other survival options, re-indentured themselves in the Caribbean. Others, once back in India, China or Java, re-indentured themselves and returned to the colonies. In researching her own family history, Bahadur notes, 'About 7 percent of emigrants arriving in Guiana in the dozen years before my great-grandmother did - 2,075 people - had been indentured before, either there or somewhere else. ${ }^{42}$ Analogous to situations of 're-trafficking' today, the re-indentured knew they were to pay off the costs for their transportation and maintenance through hard labour, that their movements would be circumscribed, and that the work and living conditions in their place of employment were harsh. Still, hope for a better life prevailed, directing them into the hands of unscrupulous middle-persons, recruiters, transporters and employers, with the expectation that the difficulties along the way were for a finite period. Today's experiences of seasonal migration for wage labour in salt pans, export fish-processing zones, strawberry farms, sex industries, domestic and care work or the kafala system, in

${ }^{41}$ The award-winning 2016 film 'Migrant Dreams' by Min Sook Lee, for example, carefully documents how some migrant farm workers in a small town in southern Canada deal with systemic oppression and exploitation from their brokers, employers and the Canadian state, http://www.migrantdreams.ca/.

42 Bahadur, p. 68. 
India, Denmark, the US, the Mekong, and the UAE, are most commonly held to represent the bulk of what is identified as human trafficking, forced labour and 'modern-slavery' in the twenty-first century. These exhibit similar qualities, with many people returning to or maintaining connections with home. ${ }^{43}$ Slavery, on the other hand, was for life and was hereditary, where the enslaved were 'alienated from all rights or claims of birth', ${ }^{44}$ and return to Africa was not an option. Few accounts of re-enslavement emerge in Caribbean history, and the concrete experience of moving from slavery into another form of unfree labour signals the distinction between the two systems. Even though plantation conditions might have been similar, there were clear boundaries between the conditions of indenture and those of slavery.

\section{Race, Gender and Sexuality}

Racialised and gendered dimensions of Caribbean indentureship can further elucidate analogies between historical and contemporary instantiations of migrant and forced labour. Caribbean history allows us to see that only certain racialised categories were deemed enslaveable (peoples who at the time were indigenous to the Americas and Africa), with blackness emerging as a critical category in the making of the 'slave' under modernity. The Caribbean indentureship experience however, was 'colour-blind'-notions of race were not foundational to the system, even while constructs of racial difference saturated indentureship and were used to justify the harsh treatment of some workers, and at times the privileging of others. The arguments that today 'modern slavery' and human trafficking do not depend on race again point to the similarities between contemporary forms of bound labour and those of yesteryear, while also serving to erase the specificity of contemporary global racialised divisions of labour. Conflating twenty-first century bound labour with slavery thus elides the significance of blackness in the making of transatlantic slavery, as well as the legacy of that anti-black racism that manifests today in the Americas through the incarceration and disenfranchisement of millions of people of African descent. It is also argued that such an erasure works politically to deny reparation claims for slavery. ${ }^{45}$ A paralleling of situations

43 See for example: Rhacel Salazar Parreñas, 'The Indenture of Migrant Domestic Workers', Women's Studies Quarterly, vol. 45, no. 1\&2, 2017, pp. 113-127. Her recent article employs the notion of indenture to describe the global conditions for Filipina migrant domestic workers who, she argues, are often classified and counted as 'trafficked victims' or 'modern slaves' by organisations such as Free the Slaves, the IOM, and the Walk Free Foundation.

44 J O'Connell Davidson, Modern Slavery: The margins of freedom, Palgrave McMillan, 2015, p. 45.

45 Handler and Reilly. 
described as human trafficking and 'modern slavery' with those of indenture could thus enhance our understandings about the ways in which race both informs and obscures labour relations under capitalism.

Women's sexuality also played a large part in recruitment processes for indenture. Accounts or analyses of indentured European women are hard to find, yet women were documented amongst the destitute, the landless, and the deported political or religious prisoners, even while details are scant. Jill Sheppard's research suggests that in 1645 soldiers in England visited 'brothels and other places of ill-repute and press-ganged 400 women of loose life to join several hundreds already on board ship for Barbados', although what became of the women is not apparent. ${ }^{46}$ From India and China historical evidence is more available. Women were deemed hard to recruit, and recruiters are recorded as having to pay up to double the amount for women than men. Moreover, Indian women were recruited not in the first place for their labour, but to tie men to the plantations-i.e. on the basis of their sexuality — to marry, provide care work, bring stability to the male labour force, and help eliminate the cost of remigration and the loss of workers. In India, 'Agents for indenture ... circulated notices in the Bihari countryside promising women that, if they migrated to the sugar colonies, they would "find husbands at once among the wealthier of their countrymen"" and in China, "prospective migrants to these colonies were given an incentive of 20 for wives', while 'women were not indentured but arrived officially as companions or wives of indentured Chinese men'. ${ }^{47}$ Women's (hetero)sexuality under indenture was of prime interest to the employers, although not for reproductive purposes - the plantocracy was not concerned with reproducing the labour force through encouraging births. Adult labour was plentiful, could be obtained cheaply, and was renewed through constant importation. ${ }^{48}$ In this way, sexual, emotional and care work for indentured Asian men was central to the women's recruitment and employment. As wage labourers they were deemed inferior to men, and were paid less even while they performed the same work in the fields, but their sexuality was highly prized by the employers. The sexualisation of, in particular, Asian indentured women, is not dissimilar to that which is described as 'sex trafficking' in the twenty-first century, in that sexual labour was, and is, an explicit part of the reasons for the recruitment and overseas employment of women. And as with the contemporary narrative, assertions of sexual agency by indentured Asian women located them in the view of the chroniclers of the time as 'immoral', 'loose' and prostitutes, leading planters at times to force women into monogamous unions. ${ }^{49}$ So too,

Sheppard, p. 49-50.

47 Bahadur, p. 36; Sheppard, p. 119. See also: Sewradj-Debipersad, p. 20.

48 P P Mohapatra, "Restoring the Family": Wife murders and the making of the sexual contract for Indian immigrant labour in the British Caribbean colonies, 1860-1920', Studies in History, vol. 11, issue 2, 1995, pp. 227-260.

49 Mohapatra; Bahadur. 
regulation of women's sexuality was heightened through narratives about the 'evils' of indentureship, reminiscent of the ways in which discourses of human trafficking work to curtail women's mobility and sexual agency.

\section{Conclusion}

While indenture was a vicious and highly exploitative system, relying on false promises to recruit workers, and confinement, abuse and violence at the site of employment, little in the narrating of Caribbean history conflates indenture and slavery, even while a rhetoric of slavery has at times been mobilised to evoke outrage and moral indignation about the conditions of indentureship. The legal status of the indentured as persons, the rights they held, the apparent choice they had to migrate and take up work in a new land, the possibilities or promise of return home, and the temporariness of their condition, all indicate that indenture was significantly different from slavery. Chroniclers of the time as well as historians and other writers have maintained distinct terms and identifications for what took place in the Caribbean from the seventeenth to the mid-twentieth centuries. Those who experienced the move from slavery into indentureship could also likely have spoken about corporeal, physical and economic differences.

Moreover, histories of the simultaneity of indentureship and slavery in the Caribbean enable us to pinpoint important distinctions between these labour systems, and suggest that labelling unfree or forced labour today as human trafficking or 'modern slavery' elides and obscures specificities and differences in legal status and conditions of work and life. As Julia O'Connell Davidson notes, 'Historical evidence ... underlines the dangers of de-contextualizing elements of human experience of relationships from entire bundles of rights, obligations, immunities and privileges that go with particular social statuses at particular moments in time. ${ }^{50}$ Even from this initial reading of a 'New World' past, indenture appears far more analogous to conditions of unfree labour today than transatlantic slavery, suggesting that it is a more useable and less salacious term than 'modern slavery' and its counterpart, human trafficking. Thus, rather than appealing to morality or fears about captivity through the notion of slavery or a discourse of human trafficking, we could seek to learn from the past as well as build strategies for change that perform critical analyses of everyday practice with care and respect for that past. In this regard, Caribbean history has much to offer to the contemporary debate. Nevertheless, this is not an argument to simply exchange terms. While a politics of indenture could deflate some of the hype and moral panic that comes with notions of 'modern slavery' and human trafficking, its adoption would not necessarily get 'to the bottom of things'. Migrant rights,

\footnotetext{
50 O’Connell Davidson, p. 69.
} 
labour rights, sex workers' rights and economic justice will continue to require our attention, if the goal is equality and safety for all.

Kamala Kempadoo is Professor in the Department of Social Science at York University in Toronto, Canada. She publishes and speaks widely on human trafficking and sex workers' rights from critical antiracist and transnational feminist perspectives. Her main publications include Global Sex Workers: Rights, resistance and redefinition (1998); Sun, Sex and Gold: Tourism and sex work in the Caribbean (1999); Sexing the Caribbean: Gender, race and sexual labor (2004), and Trafficking and Prostitution Reconsidered: New perspectives on migration, sex work and human rights (2005/ 2012). She is the 2017 recipient of the Distinguished Scientific Achievement Award of the Society for the Scientific Study of Sexuality. Email: kempadoo@yorku.ca 


\title{
Anti-White Slavery Legislation and its Legacies in England
}

\author{
Laura Lammasniemi
}

\begin{abstract}
This paper argues that the foundation of modern anti-trafficking laws in England and Wales was created at the turn of the twentieth century, during the peak of white slavery hysteria. It shows that a series of interrelated legal interventions formed that foundation. While white slavery as a myth has been analysed, this paper turns the focus on legal regulation and shows why it is important to analyse its history in order to understand modern responses to trafficking. It focuses, in particular, on the first legal definition of victims of trafficking, involvement of vigilance associations in law reform, and on restrictions put in place on women's immigration. Finally, it reflects on how laws enacted at the turn of the twentieth century still resonate with those of today.
\end{abstract}

Keywords: trafficking in women, white slavery, legal history, victimhood, migration, England

Please cite this article as: L Lammasniemi, 'Anti-White Slavery Legislation and its Legacies in England', Anti-Trafficking Review, issue 9, 2017, pp. 64-76, www.antitraffickingreview.org

\section{Introduction}

The concepts of human trafficking and white slavery did not appear ex nibilo: neither in the modern-day context, nor at the turn of the twentieth century. The UN Protocol to Prevent, Suppress and Punish Trafficking in Persons, Especially Women and Children (UN Trafficking Protocol), adopted in 2000, is often credited with the first international definition of human trafficking and with marking the beginning of the regulation of trafficking in persons, both in the domestic and

This is an open-access article distributed under the terms of the Creative Commons Attribution License (CC-BY) Under the CC-BY license, the public is free to share, adapt, and make commercial use of the work. Users must always give proper attribution to the authors and the Anti-Trafficking Review. 
international spheres. ${ }^{1}$ This article argues otherwise. It focuses on the legislation of 'white slavery', as trafficking in women was then called, enacted between the years 1885 and 1912, a hitherto neglected part of the history. It argues that the foundation of modern anti-trafficking legislation in England was created during those years through a series of legal interventions, and that the legacies of those laws are still present. More specifically, the legal interventions between the years 1885 and 1912 (a) created a legal definition of the trafficking victim; (b) outlawed procurement and transnational trafficking for sexual exploitation; (c) formalised the relationship between the state and the charitable/vigilance associations; and (d) created provisions to monitor and restrict the migration of women.

While scholars such as Jo Doezema and Jane Scoular have noted the ideological parallels between the narratives of the past and present, there has been no comprehensive and systematic inquiry into the origins of the legal regulation of white slavery/trafficking in England. ${ }^{2}$ This paper aims to bridge that gap by focusing on the key elements of white slavery legislation and offering reflections on how it still resonates today.

The article utilises legal historical methodologies and in particular, archival research. It draws from various archival collections such as the Home Office and the Metropolitan Police archives held in the UK National Archives in London. It also utilises the archives of different organisations held at the Women's Library in London, such as those of the National Vigilance Association (NVA), an evangelical moral-purity organisation that dominated the field at the time. The archival collections assist in not only mapping legal history but in understanding why these laws came into existence when they did, why they were enacted in the form that they were, and whose views and voices were excluded from law reform.

1 S Scarpa, Trafficking in Human Beings: Modern slavery, Oxford University Press, Oxford, 2010; K H Heinrich, 'Ten Years After the Palermo Protocol: Where are protections for human trafficking?', Human Rights Brief, vol. 18, issue 1, 2010, p. 2. Also, many NGOs and those responsible for enforcing the laws traditionally refer to the UN Trafficking Protocol as the first document to tackle trafficking, see for instance Crown Prosecution Service, Human Trafficking, Smuggling and Slavery, retrieved 1 August 2016 http://www.cps.gov.uk/legal/h_to_k/human_trafficking_ and_smuggling/.

2 J Doezema, 'Loose Women or Lost Women? The re-emergence of the myth of "white slavery" in contemporary discourses of "trafficking in women", Gender Issues, vol. 18, no. 1, 2000, pp. 23-50; and Sex Slaves and Discourse Masters - The construction of trafficking, Zed Books, London, 2010; J Scoular and V Munro, 'Harm, Vulnerability, and Citizenship: Constitutional concerns in the criminalization of contemporary sex work' in R Duff et al. (eds.), The Constitution of the Criminal Law, Oxford University Press, Oxford, 2013; J Scoular, The Subject of Prostitution: Sex work, law, and social theory, Routledge, London, 2015. 


\section{Defining White Slavery}

In 1881, a Select Committee of the House of Lords was established to conduct an inquiry on the Law Relating to the Protection of Young Girls, with a particular focus on traffic in women from, and to a lesser extent to, England. It was founded following Alfred Dyer's scandalous account of traffic in English girls to European brothels called The European Slave Trade in English Girls. ${ }^{3}$ Dyer and various public officials gave testimony to the Select Committee. In their testimonies, public officials one after another disputed traffic in 'innocent girls' and testified that the English girls who had travelled to Belgium and France to work in maisons de débauche did so willingly, but were often deceived or unhappy with the working conditions on arrival and then moved to another house or remained working in conditions that were exploitative. ${ }^{4}$ However, neither Scotland Yard nor the London Metropolitan Police perceived white slavery or forced prostitution as a problem. Scotland Yard found isolated cases of exploitation but no evidence of systematic traffic in women. ${ }^{5}$ Similarly, Sir Edward Ridley Colborne Bradford, the then head of London Police, argued that 'genuine cases are few far and in between'. ${ }^{6}$

In 1912 at the height of the second wave of white slavery hysteria, Teresa BillingtonGreig, the founder of the Women's Freedom League, analysed crime reports and contested the existence of white slavery. She published her findings in 'The Truth about White Slavery' where she described the narrative of white slavery as:

... unwilling, innocent girls were forcibly trapped; that by drugs, by false message, by feigned sickness, by offers of or requests for help and assistance, girls were spirited away and never heard of again; that these missing girls, often quite young children, were carried off to flats and houses of ill-fame, there outraged and beaten, and finally transported abroad to foreign brothels under the control of large vice syndicates.

A Dyer, The European Slave Trade in English Girls, Dyer Brothers, London, 1881. Report, Select Committee of the House of Lords.

5 New Scotland Yard, 'Return Cases of Alleged Procuring of Young Women to Become Prostitutes by Foreigner', 9 April 1903, London National Archives (NA) Home Office Papers (HO) HO 144/535/A48032/148.

6 Letter, Sir Edward Ridley Colborne Bradford to the Under Secretary of State, 10 June 1901, NA HO 144/535/A48032/1-48.

7 T Billington-Greig, 'The Truth about White Slavery', The English Review, June, 1913, pp. $425-428$. 
The dominant white slavery discourse, as highlighted by Billington-Greig, was largely constructed around the crude juxtaposition of dangerous, foreign men and innocent, white women. The similarities with modern-day anti-trafficking rhetoric are striking. ${ }^{8}$ Both narratives, particularly in popular culture and the media, toy with details of innocence and ruin of the victim, coupled with the demonisation of foreign men. Victimhood in the white slavery discourse was constructed not only in terms of gender and class but also race. Anxieties about race, nationality and immigration underpinned much of the debate on trafficking. Race was both explicit and implied in the white slavery discourse. It was not until 1921 when the League of Nations International Convention to Combat the Traffic in Women and Children replaced the term 'white slavery' with the racially neutral 'traffic' in international law. ${ }^{9}$ References and comparisons to transatlantic slavery were frequent in the campaigns to end trafficking on all sides. Campaigners of women's rights and evangelical vigilance toyed with the 'racialized metaphor' of white slavery from the beginning of the movement. ${ }^{10}$ Dyer had called white slavery 'more cruel and revolting than negro servitude' as it was directed at women. ${ }^{11}$ As Ann Irwin has argued, in the white slavery discourse 'the degraded black slave was replaced by the demoralized white woman'. ${ }^{12}$ Furthermore, the association of race and slavery had a shock factor, and allowed white slavery to be discussed in a moral vacuum as a concept of its own that was separate from other forms of servitude and labour exploitation.

It would be wrong, however, to state that whiteness was only construed in biological and explicit terms in the discourse. Whiteness was rooted beyond race-in class, nationality, and perceived purity. Prostitution was viewed by many vigilance campaigners as demeaning and de-whitening. Stories of English prostitutes who

8 Doezema, 'Loose Women or Lost Women?'; Doezema, Sex Slaves and Discourse Masters.

9 The League of Nations issued a Covenant on 29 April 1919 that the League of Nations was to oversee the international movement and legislation against traffic in women and children. According to Article 23(c) of the League of Nations Covenant, the League were to have 'general supervision over the execution of all agreements with regard to the traffic in women and children', but no general guidelines were issued as to how this consolidation was to happen or what the specific powers of the League of Nations were on this issue. The League of Nations passed the International Convention to Combat the Traffic in Women and Children in 1921 - the main function of the Convention was to amplify and strengthen the 1904 Agreement and the 1910 Convention discussed in a later section. International Bureau, 'Traffic in Women and Children', WL 4/NVA S107-134 FL110.

10 R Attwood, 'Vice Beyond the Pale: Representing "white slavery" in Britain, c.1880 - 1912', Thesis, UCL, 2013.

11 Dyer, p. 4.

12 M A Irwin, "White Slavery" as Metaphor-Anatomy of a moral panic', Ex Post Facto: The History Journal, vol. V, 1996. 
had non-white clients or boyfriends were told with particular horror and disdain. The NVA went so far as to state that the 'cheapening of white womanhood is one of the worst features of White Slave Traffic'13 and that the 'cheapening' of white women in this manner 'must result [in] some cheapening of prestige' of the British Empire. ${ }^{14}$ The whiteness in the white slavery discourse was thus more than a term of biology; it was a way to determine purity and patriotism.

\section{Creating the Foundation for Anti-Trafficking Laws}

The campaigns against white slavery culminated in a rally in Hyde Park, London, in August 1885, when tens of thousands of people demanded that white slavery be outlawed and the age of consent for girls be raised. This section introduces the key legal interventions enacted during 1885-1905, beginning with the Criminal Law Amendment Act 1885 (CLAA 1885). Furthermore, it will show that for the purposes of trafficking, the CLAA created two tropes of victimhood: that of the innocent woman procured and that of the drugged/detained prostitute. Both of these tropes proved unworkable in courts.

The measure that was adopted first was the CLAA 1885. The House of Lords Select Committee had already recommended changes to the law in 1881 in relation to white slavery, but it took a number of bills before the CLAA was finally enacted. ${ }^{15}$ Hysteria around another scandalous reportage on child prostitution in London ${ }^{16}$ forced Parliament to respond and enact the CLAA 1885. The Act did not mark a great departure from the earlier bills. Section 5 of the Act raised the age of consent from thirteen to sixteen for girls as demanded by the public. Controversially, the Act also outlawed brothel keeping and procurement of women for prostitution. The CLAA 1885 and 1912 have been examined at length in relation to the age of consent and the suppression of brothels. ${ }^{17}$ The following therefore focuses on the creation of the legal definition of the victim of trafficking. ${ }^{18}$

13 National Vigilance Association (NVA), In the Grip of the White Slave Trader, NVA, London, 1911, p. 65.

14 Ibid.

15 Report, Select Committee of the House of Lords.

16 W T Stead, 'The Maiden Tribute of Modern Babylon I', Pall Mall Gazette, 6 July 1885.

17 J Laite, Common Prostitutes and Ordinary Citizens: Commercial sex in London 1885 1960, Palgrave Macmillan, London, 2012, pp. 54 -69; P Bartley, Prostitution: Prevention and reform in England, 1860-1914, Routledge, London, 2012, pp. 155-178.

18 Lucy Bland, Julia Laite and Judith Walkowitz have analysed the Criminal Law Amendment Act 1885 in the context of regulation of prostitution. See in particular: L Bland, Banishing the Beast: Feminism, sex and morality, Tauris Parke, London, 2001; 
The CLAA 1885 was significant for creating a definition of a trafficked girl-the involuntary prostitute-and a distinction between the innocent victim and the criminal prostitute. Yet, the definition was incidental to the main focus of the legislation. Little attention was given to this historic definition in parliamentary debates on CLA bills 1883, 1884 and 1885. The Lords focused more on the lack of safeguards against malicious prosecutions that men might be subjected to and many felt the 1884 bill was overstepping the boundaries of criminal law. ${ }^{19}$ Lord Oranmore and Brown said that he believed that there were very few of their Lordships who had not, when young men, been guilty of immorality'. ${ }^{20}$ To ensure men could not be blackmailed, the final CLAA bill was amended so it only applied to women 'who were not being a common prostitute, or of known immoral character'.

Section 2(1) of the CLAA 1885 states that it is a misdemeanour to procure or attempt to procure 'any girl or woman under twenty-one years of age, not being a common prostitute, or of known immoral character, to have unlawful carnal connexion, either within or without the Queen's dominions'. By including the words 'not being a common prostitute, or of known immoral character, the section excluded from the scope of the law not only those working in prostitution but also any women considered promiscuous or unrespectable. Simultaneously, the section marked the beginning of the legal distinction between the deserving innocent victim and the 'common prostitute'. The definition of a 'common prostitute' was not provided in the legislation and so she was implicitly defined in juxtaposition to the innocent victim as immoral and responsible for her procurement. However, any woman, including a prostitute, could be procured under section 3(3) by a person who:

Applies, administers to, or causes to be taken by any woman or girl any drug, matter, or thing, with intent to stupefy or overpower so as thereby to enable any person to have unlawful carnal connexion with such woman or girl.

J Laite, Common Prostitutes and Ordinary Citizens; J Walkowitz, Prostitution and Victorian Society - Women, class and the state, Cambridge University Press, Cambridge, 1980. Frank Mort, Jeffrey Weeks and Edward Bristow have analysed it in the context of sexuality and vigilance. See in particular: J Weeks, Sex, Politics and Society - The regulation of sexuality since 1800, $3^{\text {rd }}$ edition, Pearson, London, 2012, and E Bristow, Vice and Vigilance - Purity movements in England since 1700, Gill and Macmillan, Dublin, 1977.

19 House of Lords Debate, 18 June 1883, second reading.

20 House of Lords Debate, 24 June 1884. 
The wording of the section creates another powerful image: that of a woman who is drugged and then violently carried away. The subsequent subsections outlawed domestic and international trafficking by making it an offence to procure a woman or girl for the purpose of prostitution abroad or within the UK. ${ }^{21}$ However, if a woman was already living in a brothel, she could not be procured or trafficked, reinforcing the division between prostitutes and victims. In a number of ways, then, the Act created a distinction between virtuous virgins who embodied social purity, and the Other - the common and immoral prostitute.

Despite the high-profile nature of the CLAA, there were few prosecutions under the trafficking provisions. The prosecutions were widely reported in local, and at times national, newspapers. These reports provide insights into the enforcement of the Act. The cases reveal a complex picture of prostitution, consent and exploitation. The prosecution of Louisa Hart was a case where the boundaries between the procurer and the victim became blurred. Hart was convicted for criminally procuring young girls to be assaulted by an unknown man, or men. In court, she claimed that the girls in question were not procured but had already been working as prostitutes, and she was simply allowing them to use her premises for what was a voluntary vocation. Furthermore, Hart claimed she thought they were both aged sixteen and above, emphasising the age of consent. It was later proven that the girls in question were twelve and thirteen respectively and both refuted Hart's claim that they were engaged in prostitution prior to meeting her. Hart was convicted and sentenced to five years' imprisonment with hard labour. She was only twenty-one at the time of the conviction. In her testimony, she claimed to have been married off when she herself was only fifteen. Hart implied she had been working as a prostitute ever since and under the influence, if not coercion, of her husband. Hart was the only person on trial, and on sentencing the court did not consider her background, age, or the influence of her husband. ${ }^{22}$

Cases such as that of Hart show a far more complex reality than that which was envisaged by the lawmakers and reformers. The juxtaposition of the innocent victim and criminal prostitute created by the law did not conform to the reality of women who were arrested under the Act. As demonstrated above, it had two victim tropes: that of the innocent woman procured under section 2 and that of the drugged/detained prostitute under section 3. Women such as Hart did not fit into these tightly defined categories, making them a target of these laws.

21 Sections 2(3), (4) CLAA 1885 respectively.

22 Morning Post, 10 March 1886. 


\section{Vigilance Associations' Action in the National and International Sphere}

Vigilance associations, founded on moral-purity ideals, played an integral part in the lobbying for and later enforcement of white slavery laws both in England and Europe, none more so than the NVA and its international arm, the International Bureau for the Suppression of the White Slave Traffic (International Bureau) ${ }^{23}$ The International Bureau was involved in the drafting process of the international agreements against white slavery, namely the Agreement for the Suppression of the 'White Slave Traffic' 1904 (the 1904 Agreement) and the International Convention for the Suppression of the White Slave Traffic 1910 (the Convention), and the NVA was in charge of their domestic enforcement. ${ }^{24}$ The London Conference of the International Bureau in 1899 set in motion the drafting of the international accords. The resolutions show that the International Bureau intended to focus on law reform campaigning from the beginning, and as such embraced cooperation with the state. A key resolution adopted by the first International Congress held in 1899 puts forward a draft international agreement that includes articles for the criminalisation of procurement and traffic, as well as measures for border/port control..$^{25}$

The resolution gives a clear indication of the aims and organisational ethos of the International Bureau, both in terms of the scope of the legislation and their role in the process. The aim of the organisation was to lobby for international legislation in the field of trafficking, in an era when international treaty law was still in its early days. The resolution is also a clear indication of the International Bureau's relationship with the state. It had taken on drafting legislation without the involvement of state bodies in the process. The role of the charitable and civil society organisations in the enforcement of the treaty is also cemented in the draft proposal. The resolution designates these organisations — not the state officials as bodies responsible for border control. The resolution also implies that the monitoring of points of entry is the responsibility of the charitable organisations in order to 'protect emigrants on their arrival' and to share information 'as to the emigration of women under suspicious circumstances'. ${ }^{26}$ The national committees of the International Bureau were established in various countries around the world

23 Various National Vigilance Association (NVA) collections, Women's Library Archives at London School of Economics (WL) WL 4/IBA.

24 For a full discussion on the enactment of the accords, see S Limoncelli, The Politics of Trafficking - The first international movement to combat the sexual exploitation of women, Stanford University Press, Stanford, 2010.

25 Minutes of the International Congress on the White Slave Traffic, Westminster Palace Hotel, London 21 and 23 June 1899, WL 4/IBA Box FL 192.

26 Ibid. 
and they were already engaging in this task without formal agreements with the state.The committees reported on regular intervals back to the London headquarters on the progress and for example, on how many women they had interviewed. They monitored and reported back to the International Bureau on levels of suspected traffic and prostitution through patrolling railway stations and ports where they greeted girls suspected of being a 'white slave', or indeed a foreign prostitute. While the most oppressive aspects of the white slavery agreement, such as the repatriation of foreign prostitutes, were not part of the early resolutions, the national committees provided funds and campaigned for the repatriation of foreign prostitutes even prior to the ratification of the 1904 Agreement. ${ }^{27}$

In England, the NVA had secured a quasi-governmental position ahead of the ratification of the 1904 Agreement. The NVA had suggested to Akers-Douglas, the then Home Secretary, that 'the International Bureau shall be responsible for all information forwarded to Scotland Yard, and shall be acknowledged by them as the medium of official communication'. They argued that nominating the International Bureau for this task would 'be in the interest of the work and the authorities' ${ }^{28}$ All their proposals were accepted by Akers-Douglas, and the International Bureau/NVA were given a trial of six months to monitor ports and railway stations. Akers-Douglas welcomed the assistance of the organisations and agreed that they were 'in the best position' to take on its enforcement. ${ }^{29}$ When the Agreement was formalised and came into force, the International Bureau/NVA had already received powers to question migrant women both at points of arrival and when in custody, and ultimately to deport them.

Controlling immigration soon became the focus of anti-white slavery efforts. In the early years, and around the Belgium scandal described by Dyer, the focus had been on preserving the purity of English girls. At the beginning of the twentieth century that focus had shifted from protection of girls to protecting the state and society from the threat posed by foreign girls. This was partially enabled by the introduction of the first formal restrictions on immigration under the Aliens Act 1905. The 1905 Act was carried through by anti-Jewish sentiment and agitation and it marked a radical change and the beginning of systematic immigration control in Britain. ${ }^{30}$ The Act was not directed at women - prostitutes or otherwise. Rather, it was directed first and foremost against the Jewish immigrants from Eastern Europe, and it was carried through by xenophobic, mainly anti-Jewish, sentiment

\footnotetext{
Minutes of the International Congress on the White Slave Traffic, London, June 1899-July 1904, WL 4/IBA Box FL 192.

28 Minutes of Deputation, 20 March 1903, NA HO 144/535/A48032/1-48.

29 Ibid.

30 R Attwood, 'Vice Beyond the Pale'.
} 
and agitation. ${ }^{31}$ Yet, the regulation of female immigration, and particularly that of the 'prostitute class', as the Home Secretary put it, was enabled by this law. ${ }^{32}$ Despite its anti-Semitic origins, the Act had a profound impact on foreign women working in prostitution. It set in place the framework for immigration control that in the following years was tightened, particularly in relation to foreign prostitutes. These domestic laws, together with the international white slavery agreements, created complex powers of surveillance and repatriation over foreign women suspected of prostitution.

The Aliens Act 1905 allowed for the newly established immigration officer to inspect ships and question immigrants to ascertain whether they were of the 'undesirable' kind. ${ }^{33}$ It also allowed for an expulsion of those convicted of an offence for which the court had the option to impose imprisonment without the option of a fine. The exception to this was prostitution; if convicted of offences related to prostitution, the court should recommend that an expulsion order be made 'in addition to or in lieu' of the sentence. ${ }^{34}$ In relation to foreign-born women suspected of prostitution, the Act was used together with prostitution legislation, mainly the Vagrancy Act, to deport women. ${ }^{35}$ The white slavery accords enabled police surveillance of women suspected of being prostitutes under the premise of white slavery. Their steps were traced from their morning coffees to meetings with clients, then occasional meetings with suspected 'procurers' or 'white slavers'. But most of the case law shows that it was again women, rather than the suspected 'white slavers', who found themselves on trial, often waiting for deportation. ${ }^{36}$

\section{Conclusion: Legacies of the white slavery laws}

The legacies of white slavery legislation at the turn of the twentieth century are inescapable in the present day. The language of slavery has entered the public and legal discourse again, the debates on criminalisation are as divisive as they ever were, and legal responses to trafficking are arguably even more invasive than they were at the height of white slavery hysteria in the early twentieth century. In the UK, there has been a plethora of legislation in the field of trafficking in recent years, including a dedicated Modern Slavery Act 2015. Yet, the legal framework remains complex

31 B Gainer, The Alien Invasion - The Origins of the Aliens Act of 1905, Heinemann, London, 1972; D Glover, Literature, Immigration, and Diaspora in Fin-de-Siècle England - A cultural history of the 1905 Aliens Act, Cambridge University Press, Cambridge, 2012.

32 House of Commons Debate, 29 March 1904.

33 Section 1 of the Aliens Act 1905.

34 Section 3(1)(a) of the Aliens Act 1905.

35 Metropolitan Police (MEPO) Archives; NA MEPO 3/197.

36 Ibid. 
and fragmented. While acknowledging that the discourse has evolved and shifted, the legal legacies have remained remarkably static. Theresa May chose fighting the 'evil' of modern slavery as one of her first challenges as Prime Minister. ${ }^{37}$ As Home Secretary she often spoke of the issue, ${ }^{38}$ and introduced the Modern Slavery Act 2015: a law that has been accused by Anti-Slavery International of prioritising criminalisation over prevention or protection. ${ }^{39}$ During her time as the Home Secretary, the Home Office also introduced anti-trafficking measures that allowed for questioning of young women in their home countries before they even attempt to migrate. ${ }^{40}$ Furthermore, the Salvation Army, a Christian non-profit organisation that was active in the field at the turn of the twentieth century, now operates as the main government contractor providing victim assistance services. In the presentday, the term 'modern slavery' is commonly used in the UK as an overarching term to describe human trafficking, forced labour, debt bondage and child labour. While 'modern slavery' implies the offence is a new one, the legal and policy responses adopted today are remarkably similar to those adopted at the turn of the twentieth century.

Legislation, policies and campaigns initiated in recent years have had a strong antiimmigration focus at their core. They show that anti-trafficking legislation is closely intertwined with immigration control, and overall, criminalisation of trafficking is interlinked with criminalisation and fears of immigration. In a world of nation states and immigration control, underpinned by racism and xenophobia, it is nearly impossible for many people to cross borders without facilitators. Many migrants resort to illegal means of travel and some of them are deceived or abused in the process of migration or on arrival. Nandita Sharma has argued that they 'are victimized by border control practices and the ideologies of racism, sexism, and nationalism that render unspectacular their everyday experience of oppression and exploitation'. ${ }^{41}$ She further notes that the moral panic about trafficking 'serves to legitimize increasingly regressive state practices of immigration control'. ${ }^{42}$ The rhetoric of protection and female helplessness-similar to that utilised by vigilance associations at the turn of the twentieth century-has been once again utilised by

37 'Modern Slavery: Theresa May vows to defeat “evil”", BBC, 31 July 2016.

38 Editorial, "Theresa May Makes Modern Slavery her "Personal Priority", The Guardian, 24 November 2013.

39 Anti-Slavery International and Anti-Trafficking Monitoring Group, 'Big Step in the Right Direction but Deficiencies Leave Us - and Victims of Modern Slavery Wholly Unsatisfied', retrieved 1 August 2016, https://www.antislavery.org/analysismodern-slavery-act/.

40 HM Government, 'Human Trafficking: The Government's strategy', 19 July 2011, chapter 5 .

41 N Sharma, 'Anti-trafficking Rhetoric and the Making of a Global Apartheid', NWS A Journal, vol. 17, no. 3, 2005, pp. 88-111, emphasis original.

42 Ibid. 
states through the anti-trafficking rhetoric to promote border control. For example, the 2011 Human Trafficking Strategy gave the then UK Border Agency powers to interrogate and detain female migrants both in their home countries and at points of entry into the UK. ${ }^{43}$ The strategy states that this action is 'enhanced ability to act early, before the harm has reached the UK', implying that it is the UK that needs to be protected from the threat posed by the trafficked persons. This strategy is not new, nor are the powers it has given unprecedented. The section on the early twentieth century White Slavery Agreement and the domestic Aliens legislation showed that these are the exact tactics that were utilised by the vigilance campaigners who were given the powers to question and detain women at ports of entry into the United Kingdom.

The difficulty in defining victimhood and understanding vulnerability that was highlighted in the first part of this article continues to the present day, especially in court cases. The ideal victim trope that strongly echoes the CLAA construction of victimhood has been persistent in trafficking cases, particularly in relation to historical victims. A historical victim is someone who has been a victim of trafficking in the past but is not considered to be one at the moment of determination. In the cases of historical victims or in cases of trafficked persons exercising a level of control over their lives, the courts have arguably failed to adequately acknowledge exploitation and its impact. ${ }^{44}$ Instead, the trafficked persons have been held liable for the crimes they have committed while living in exploitative circumstances. In these cases, the relative control and active subjectivity have transformed the trafficked persons from victims into perpetrators. They have been marginalised by the very laws that were set out to protect them, echoing the case of Hart discussed in relation to the similar failures of the CLAA.

In conclusion, this paper has shown how key elements of anti-trafficking legislation were put in place already between 1885 and 1905 . While parallels between white slavery and modern trafficking discourse have been drawn before, this paper has shown that the legal foundations for current anti-trafficking laws were created at the peak of white slavery hysteria. Although these laws were responding to white slavery campaigns, the lives of all women who would today be described as migrants and sex workers came under deeper control with every new legal intervention. The legislation did not, and could not, provide protection against the exploitation of women within prostitution and otherwise, as it focused on procurement and immigration entry points and loss of innocence rather than

3 HM Government, 'Human Trafficking: The Government's Strategy'.

44 See for example: $\mathrm{R} v$ O [2008] EWCA Crim 2835; R v LM [2010] EWCA Crim 2327; $R v N$ and $R v$ Le [2012] EWCA Crim 189. 
ANTI-TRAFFICKING REVIEW 9 (2017): 64-76

continuing acts of exploitation. It framed white slavery as a matter of criminal or immigration law, but did not acknowledge the wider structural factors behind female poverty and inequality_much like present-day anti-trafficking initiatives.

Laura Lammasniemi is a senior lecturer at Anglia Ruskin University and a teaching fellow at SOAS (School of Law). She has recently obtained her PhD from Birkbeck College, University of London. Her thesis was entitled The Origins of Anti-Trafficking Legislation: Codifying female victimhood and criminality in England, 1880-1920s. Her research focuses on regulation of gender and class, mainly from a historical perspective.Email: 1131@soas.ac.uk 


\title{
Historicising 'Irregular' Migration from Senegal to Europe
}

\author{
Stephanie Maher
}

\begin{abstract}
Contemporary discourses on migration from West Africa to Europe tend to frame migrants as victims of syndicated trafficking cartels that truck in human desperation. As part of this narrative, migrants are increasingly portrayed as 'modern-day slaves' in need of humanitarian protection. In both media and policy circles, African migrants are commonly referred to as desperate travellers who fall prey to exploitative 'slave traders' on their clandestine journeys to Europe. And yet, such framings do not adequately account for the ways in which migration from West Africa to Europe has a long and profound history, and thus does not sufficiently correspond to histories of enslavement. Nor do such framings appreciate how contemporary movements within and outside West Africa are informed by interrelated political genealogies that tie Europe to Africa in mutually dialectic ways. Focusing on the case of Senegal, this article aims to disrupt the 'migrant as slave' narrative by looking back at the histories of regional and international mobility that continue to shape population movements out of Senegal today.
\end{abstract}

Keywords: human trafficking, irregular migration, Senegal, Frontex, securitisation, slave traders

Please cite this article as: S Maher, "Historicising "Irregular" Migration from Senegal to Europe', Anti-Trafficking Review, issue 9, 2017, pp. 77-91, www.antitraffickingreview.org

\section{Introduction}

In recent years, migration from Africa to Europe has gained widespread global attention. The seemingly endless wave of overloaded boats crossing the Mediterranean has been portrayed as a full-scale humanitarian crisis, with over

This is an open-access article distributed under the terms of the Creative Commons Attribution License (CC-BY) Under the CC-BY license, the public is free to share, adapt, and make commercial use of the work. Users must always give proper attribution to the authors and the Anti-Trafficking Review. 
5,000 dead at sea in 2016. ${ }^{1}$ The fact that people would be forced to risk their lives to migrate is frequently blamed on the presence of human smugglers and traffickers, whose criminality is uncritically assumed. ${ }^{2}$ Indeed, in 2015, Italy's foreign minister, Paolo Gentiloni, characterised smugglers as ' $21^{\text {st }}$-century slave traders' ${ }^{3}$ Framing migration facilitators as absolute criminals and migrants as consummate victims overlooks the extent to which border controls and enforcement policies have created the conditions of risk and illegality through which both facilitators and migrants must navigate. ${ }^{4}$ This article asks what it means to call migration facilitators modern-day 'slave traders'. Is this an accurate assessment? And what can history tell us about such framings?

This article examines how Senegalese migrations-both regionally in West Africa and across the Mediterranean to Europe-are historically profound. It explores the interrelated evolution of immigration policies that were integral to national political projects and discourses on nationhood in both France and Senegal in the mid-twentieth century, and in European Union states and Senegal in the late twentieth century. It also attends to more recent militarised campaigns mobilised to combat 'irregular' movements within and out of West Africa. That migratory patterns have been evolving over time suggests that there is something of a historical continuity that ties Europe to Africa in meaningful ways. More recent immigration laws, and the border enforcements they underwrite, are not immutable and self-evident, but should be seen as the product of internal and external political dynamics both in African and European contexts. Appreciating

Mortality estimates should be approached cautiously, as the real death toll is likely much higher. See: T Brian and F Laczko (eds.), Fatal Journeys: Tracking lives lost during migration, International Organization for Migration, Geneva, 2014. Though fewer migrants arrived in Europe in 2016 (arrivals were down to 363,348 from over 1 million in 2015), the death toll was significantly higher (5,079 in 2016 as compared to 3,771 in 2015). See: International Organization for Migration, 'IOM counts 3,771 migrant fatalities in Mediterranean in 2015', 5 January 2016, https:// www.iom.int/news/iom-counts-3771-migrant-fatalities-mediterranean-2015 and 'Mediterranean migrant arrivals top 363,348 in 2016; Deaths at sea: 5,079', 6 January 2017, https://www.iom.int/news/mediterranean-migrant-arrivals-top363348-2016-deaths-sea-5079.

2 See: UNODC, 'Smuggling of Migrants: The harsh search for a better life', https:/ /www.unodc.org/toc/en/crimes/migrant-smuggling.html.

3 K Seiff, 'A Smuggler's Haven in the Sahara', The Washington Post, 20 July 2015, http://www.washingtonpost.com/sf/world/2015/07/20/a-remote-city-ofsmugglers/.

4 L Achilli and G Sanchez, "What does it mean to disrupt the business models of people smugglers?', Policy Brief, Robert Schuman Centre for Advanced Studies, European University Institute, Fiesole, April 2017. 
the historical variability of human movements out of West Africa, and the extent to which they have become increasingly criminalised, disrupts the dominant narrative of facilitated migration as a 'modern-day slave trade' by highlighting how changing politics have actually created the conditions for clandestine migration facilitation to flourish.

\section{Early Histories of Mobility, 1500-1900}

Mobility has been a central feature of West African societies for centuries. Political historian Boubacar Barry attributes this mobility, at least in part, to the region's physical geography. ${ }^{5}$ Demarcated by the Senegal River in the north and the Gambia River to the south, with a vast semi-arid basin in between, the Northern Senegambia region was something of an agricultural granary and commercial crossroads during the fifteenth through seventeenth centuries. The large rivers functioned as riparian highways along which goods and people were shuttled back and forth from the coast to the hinterlands. As such, pre-colonial Senegambia was characterised as a 'terminus for incoming populations and a point of departure for migrants on the move'. ${ }^{6}$

Various ethnic groups used regional mobility as a way to survive. Having already migrated north from the Futa Jallon region in modern-day Guinea, the Soninke of the Senegal River Valley pursued a combination of livelihood strategies that often necessitated varying degrees of mobility. ${ }^{7}$ Agricultural calendars revolved around the monsoon season lasting from June to September, which meant that during the dry season people could engage in temporary labour and trading activities. The subsequent pattern of alternating sedentary and mobile labour resulted in episodic but established cyclical movements in the region. Not only was the Soninke homeland located between the commercially vibrant Saharan zone and the Senegal River basin, it encompassed the actual river itself, which accommodated floating trading stations that facilitated the transport of grain and groundnut harvests through the region. Across the river, Arabo-Berber pastoralists migrated from the Saharan littorals to the river in the dry season to graze their herds and trade livestock for sorghum and millet. ${ }^{8}$

5 B Barry, Senegambia and the Atlantic Slave Trade, Cambridge University Press, Cambridge, 1998.

6 Ibid., p. 3 .

$7 \quad$ F Manchuelle, Willing Migrants: Soninke labor diasporas, 1848-1960, Ohio University Press, Athens, 1997.

8 R Austen, Trans-Saharan Africa in World History, Oxford University Press, Oxford, 2010 , p. 8. 
Up until the fifteenth century, trade, and the mobility that enabled it, was oriented primarily inland towards the Sahara, which shuttled gold, salt, slaves and knowledge across the desert and connected the Mediterranean to sub-Saharan worlds. ${ }^{9}$ In the middle of the fifteenth century, trade shifted to encompass maritime routes consisting primarily of the exchange of slaves and gum arabic for European commodities. With the French abolition of the maritime slave trade in 1848, groundnut exports provided a profitable alternative to the trade in humans. ${ }^{10}$ Again, this required a relatively mobile labour force as people migrated inland during the rainy season to cultivate cash crops. French colonial authorities also frequently recruited 'security officers' from Senegal to ensure its imperial interests in other parts of Africa. ${ }^{11}$ At the same time, people regularly used relocation as a way to evade colonial administrators, military conscription, and forced labour. ${ }^{12}$ In the upper Senegal River valley, populations were known to disappear into the proverbial bush when colonial taxes and labour quotas became too onerous to bear. ${ }^{13}$ As such, mobility has been integral to Senegalese people's survival for centuries.

\section{The New Age of Migration, 1900-2000}

Populations from the Senegal River valley (including Soninke, Serer, and Toucouleur ethnic groups) constituted the first wave of Senegalese immigrants to France in the early twentieth century. After World War I, Senegalese labourers were contracted to work as merchant marines on French commercial vessels, and later settled in places like Le Havre, Marseille and Bordeaux. ${ }^{14}$ The second and more substantial wave, which followed World War II and continued until 1970, consisted mainly

9 G Lydon, On Trans-Saharan Trails: Islamic law, trade networks, and cross-cultural exchange in nineteenth-century western Africa, Cambridge University Press, New York, 2010.

10 J Irvine, 'Caste and Communication in a Wolof Village', Ph.D. diss., Department of Anthropology, University of Pennsylvania, 1973, pp. 10-11.

11 B Whitehouse, 'Discrimination, Despoliation and Irreconcilable Difference: Host-immigrant tensions in Brazzaville-Congo', Africa Spectrum, vol. 44, no. 1, 2009, pp. 39-59.

12 P Geschiere, The Perils of Belonging: Autochthony, citizenship, and exclusion in Africa and Europe, University of Chicago Press, Chicago, 2009, p. 77; J Roitman, 'The GarrisonEntrepôt', Cabiers d'Études Africaines, vol. 38, no. 150/152, 1998, pp. 297-329.

13 A Clark, 'Internal Migrations and Population Movements in the Upper Senegal Valley (West Africa), 1890-1920', Canadian Journal of African Studies, vol. 28, no. 3, 1994, p. 399-420.

14 R Willems, 'Les "Fous de la Mer": Les migrants clandestins du Sénégal aux îles Canaries en 2006' in M-C Diop (ed.), Le Sénégal des Migrations: Mobilités, identités et sociétés, Karthala Press, Paris, 2008, pp. 277-303, p. 280. 
of students and veterans. Before going on to occupy administrative and civil service posts in the political bureaucracy after independence, Senegalese students were often sent first to the metropole for university education. ${ }^{15}$ Former tirailleurs Sénégalais (colonial infantry), who had fought in both world wars on the side of the French, also migrated to work in the automobile and construction industry in the metropole after demobilisation. ${ }^{16}$

This international mobility was partly a result of the fact that, in the middle of the twentieth century, France was faced with a demographic challenge: in addition to a declining birth rate and an ageing population, many young soldiers had been killed during the two successive world wars. Setting their sights on industrial recovery, which would require significant labour power, France turned to its colonies. As part of post-war reconstruction, migrants from across francophone Africa were courted to work in French industries and on infrastructure projects. Known as the Trente Glorieuses, or Thirty Glories, the three decades after the war saw the dirigiste revitalisation of France's economy, which was made possible, in part, by the importation of cheap labour from North and West Africa. The "economic logic"17 of immigration legislation between 1945 and 1973 enabled France to remedy its domestic labour shortage by extracting labour from the colonies. France established official recruitment centres in eight foreign countries, one of which was Senegal. According to French census data, the number of subSaharan Africans (mostly from Senegal and Mali) working in France increased from 17,787 in 1962 to over 80,000 in $1975 .{ }^{18}$ The 'Renault-Dakar office' thus became a euphemistic expression for the massive recruitment of Senegalsese labourers to work in the automotive industry.

Even after Senegal's independence in 1960, France continued, with varying degrees of enthusiasm, to encourage labour migration from the former colony. It was not until the oil crisis of 1973, and the beginning of economic recession, that France

15 Promising students had been migrating to France long before 1945, however. Blaise Diagne, for example, the first black African to be elected to the French National Assembly in 1914, was educated in Aix-en-Provence.

16 G Mann, Native Sons: West African veterans and France in the twentieth century, Duke University Press, Durham, 2006.

17 K Wadia, 'France: From unwilling host to bellicose gatekeeper' in G Dale and M Cole (eds.), The European Union and Migrant Labour, Berg Press, New York, 1999, pp. 171-202, p. 172.

$18 \mathrm{~N}$ Robin, R Lalou and M Ndiaye, Facteurs d'Attraction et de Répulsion à l'Origine des Flux Migratoires Internationaux: Rapport national Sénégal, IRD Éditions, Bondy, 2000, p. 34. Gregory Mann points out that figures diverged greatly, with some independent sources reporting 50,000-60,000 West African workers in France in 1963, and between 200,000 and 250,000 only six years later in 1969. See: G Mann, From Empires to NGOs in the West African Sabel: The road to nongovernmentality, Cambridge University Press, Cambridge, 2015, p. 130. 
would reconsider its open-door policy when it came to immigrant labour. That year, France abandoned its worker recruitment programmes,${ }^{19}$ though it was not until 1986 that Senegalese citizens were required to obtain an entry visa before travelling to France. ${ }^{20}$ Family reunification schemes reshaped what had been a circular form of labour migration - in which Senegalese workers periodically returned home-into a permanent form of immigration and settlement. What this meant in practical terms for aspiring migrants was that unless they knew someone in France who could sponsor their visa application under the rubric of family reunification, legal pathways to Europe were suddenly, and very drastically, limited.

The reasons for this development were multiple. The 'turning point' in French immigration policy was not simply a matter of economic crisis brought on by the oil embargo, but part of a longer process of restructuring that had been taking place in the federal bureaucracy. ${ }^{21}$ France was in the midst of redefining its sovereignty as a member of the still-nascent European Economic Community (EEC), which required a political and economic re-orientation towards Europe and away from the former colonies. As Sylvan Laurens writes, 'The decision [to close the borders] was the product of profound transformations of the [French] state apparatus which placed certain agents in a position to defend the "necessary" idea of controlling migrant flows [which had been in place] since the end of the 1960s. ${ }^{.22}$ At the same time, French racism, 'exacerbated by everyday interactions including competition for housing in the 1920s and beyond', led to growing hostility towards immigrant 'others'. ${ }^{23}$ Unrest among West African migrant workers in the metropole whose rent and labour strikes in the early 1960s publicised their deplorable living conditions and disrupted French business was also exploited by those pushing for immigration controls. ${ }^{24}$

One often neglected factor in histories of twentieth-century labour migration to Europe is the role played by West African states like Senegal in policy design with regard to migration control post-independence. And yet as Gregory Mann points out, immigration reform was not simply a unilateral decision that was handed

19 V Guiraudon, 'Immigration Policy in France', Brookings Institute, 1 July 2001, retrieved 8 August 2017, http://www.brookings.edu/research/articles/2001/07/ 0101 france-guiraudon.

20 E Vickstrom, 'Pathways into Irregular Status among Senegalese Migrants in Europe', International Migration Review, vol. 48, no. 4, 2014, pp. 1062-1099.

${ }^{21} \quad$ S Laurens, "1974" et la Fermeture de Frontières: Analyse critique d'une décision érigée en turning-point', Politix, issue 21, no. 82, 2008, pp. 69-94.

22 Ibid., p. 93.

23 I Law, Mediterranean Racisms: Connections and complexities in the racialization of the Mediterranean region, Palgrave Macmillan, New York, 2014, p. 28.

24 Mann, pp. 145-161. 
down fait accompli to former colonies. Rather, it was also the result of African states like Senegal negotiating the project of nation-building in the era of decolonisation by claiming its citizens as members in its national polity. ${ }^{25}$

Against this impulse, however, several political, economic, and demographic factors combined to ensure that migration remained an attractive option for many Senegalese from the 1960s onwards. First, between 1960 and 1988, the population in Senegal more than doubled. ${ }^{26}$ At the same time, the elimination of French subsidies on groundnut imports in 1967/1968 dealt a serious blow to Senegalese farmers, their households, and the national economy. ${ }^{27}$ The late 1960 s also marked the beginning of what would become a multi-decadal drought in the Sahel, further crippling the groundnut economy and leaving many families to seek work in urban centres. Declining exports and the global economic recession due to the oil crisis of the 1970s meant that Senegal had little choice but to accept the conditions attached to foreign structural adjustment loans, ${ }^{28}$ which exacerbated unemployment, disenfranchised a class of civil servants in urban centres, privatised industry, devalued the currency, deregulated markets, and resulted in wild fluctuations in GDP growth. ${ }^{29}$

For everyday people, quotidian existence became more difficult to ensure. One way to manage such economic volatility was to do what the Senegalese had always done: migrate elsewhere for work. While Senegalese labourers had been going to other African countries for decades, the economic crisis at home only increased

25 Mann, p. 143. See also: A Sayad, 'Immigration et "Pensée d'État", Actes de la Recherche en Sciences Sociales, vol. 129, no. 1, 1999, pp. 5-14.

26 G Pison et al. (eds.), Population Dynamics of Senegal, National Academy Press, Washington, D.C., 1995, p. 30.

27 A M Mbow, Assises Nationales: Sénégal, an 50 bilan et perspectives de refondation, L'Harmattan, Paris, 2011, p. 96. See also: C Boone, Political Topographies of the African State: Territorial authority and institutional choice, Cambridge University Press, Cambridge, 2003, p. 131.

28 Senegal became the first African state to receive a structural adjustment loan from the World Bank in 1979 as part of the Structural Adjustment 1 paradigm (SA 1). See: C Delgado, 'Africa's Changing Agricultural Development Strategies: Past and present paradigms as a guide to the future', Brown Journal of World Affairs, vol. V, issue 1, 1998, pp. 175-214.

29 Although Senegal's GDP growth rates did positively stabilise in the mid-1980s, such indicators do not necessarily reflect real living conditions for the majority of people because growth is often unevenly distributed. See: C Monga, 'Commodities, Mercedes-Benz and Structural Adjustment' in E K Akyeaampong (ed.), Themes in West Africa's History, Ohio University Press, Athens, 2006, pp. 227-264; M Ravallion, 'Growth, Inequality and Poverty: Looking beyond averages', World Development, vol. 29, no. 11, 2001, pp. 1803-1815. 
pressure to migrate for work during the 1980s and 1990s. Though France had been a major port of entry for Senegalese immigrants during the colonial period, it was not the only European country to attract Senegalese migrants in the postcolonial moment. Spain and Italy became major destinations for Senegalese on the move in the late twentieth century.

Unlike its northern neighbours, the Italian economy experienced rapid economic growth during the global recession of the 1970s. However, existing labour shortages meant that keeping a consistent flow of cheap labour from Africa was crucial to economic development. Thus Italy became a new destination for Senegalese migrants as early as the 1970 s when its less restrictive immigration policies and demand for labour made it relatively easy to access. ${ }^{30}$ In Spain, economic development looked slightly different, as Franco's death in 1975-which closely followed the first oil shock-marked the beginning of intense economic volatility. A period of rapid expansion followed, however, from 1986 to 1990, during which time semi- and low-skilled labour was in high demand to fuel the boom.

As a consequence, both Spain and Italy undertook periodic regularisations of irregular migrants, which meant that even if one had entered southern Europe illegally or overstayed a visa, many could still benefit from temporary residence and work permits as they became available. ${ }^{31}$ Between 1986 and 2002, five regularisation programmes were undertaken in Italy, which offered temporary work and residence permits to over 1.4 million applicants. Similarly in Spain between 1985 and 2005, six regularisation programmes were undertaken, offering at least half a million immigrants temporary residence, which was often renewable. ${ }^{32}$

30 Willems, p. 280. See also: K Calavita, Immigrants at the Margins: Law, race, and exclusion in Southern Europe, Cambridge University Press, Cambridge, 2005. As of 2000, there were nearly as many Senegalese immigrants in Italy as in France. See: B Jettinger, 'Informal Remittance Systems in Africa, Caribbean and Pacific (ACP) Countries: Senegal country study', Research Report, ESRC Centre on Migration, Policy and Society, Oxford, 2005, p. 5.

$31 \mathrm{~J}$ Arango and M Jachimowicz, 'Regularizing Immigrants in Spain: A new approach', Migration Policy Institute, 1 September 2005, retrieved 8 August 2017, http:// www.migrationpolicy.org/article/regularizing-immigrants-spain-new-approach.

32 A Levinson, 'Why Countries Continue to Consider Regularization', Migration Policy Institute, 1 September 2005, retrieved 8 August 2017, http:// www.migrationpolicy.org/article/why-countries-continue-consider-regularization; C Beauchemin et al., 'From Senegal and Back: Trends and routes of migrants in times of restrictions', Working Paper 21, MAFE, 2014, p. 5; N O Peréz, 'Spain: Forging an immigration policy', Migration Policy Institute, 1 February 2003, retrieved 8 August 2017, http://www.migrationpolicy.org/article/spain-forgingimmigration-policy. 
At the same time, southern European countries were between something of a rock and a hard place. They recognised the value in improving relations with other EU member states. Seeking to curry good favour with Brussels, the Spanish government instituted visa requirements for all non-EEC immigrants in 1985, and later in 1986 was welcomed into the European Economic Community. Both Italy and Spain joined the Treaty of Schengen in 1990 and 1991, respectively, after which both Mediterranean countries had vested political and economic interests in maintaining Europe's external borders with Africa. According to William BaldwinEdwards, '[S]outhern European countries are expected to bear the brunt of adjustment in restricting immigration into Europe, and are also the principal beneficiaries of EU Structural and other funds. ${ }^{33}$ The struggle between the need for cheap imported labour from Africa and the need for funds from the EU would continue to influence Italian and Spanish immigration policies for decades to come.

Back in Senegal, as economic times grew more constricted, people responded quickly to such open, if ambivalent, immigration policies in southern Europe. Many of those migrants framed their mobility through the lens of the teachings of the politically influential Sufi Murid brotherhood, ${ }^{34}$ and stories of its founding saint who resisted and evaded colonial control. Such stories infuse clandestine migration with an aura of religious sanction. ${ }^{35}$ The Murid's valuation of hard work as the path to salvation also squares easily with opportunities to labour abroad, especially when the job opportunities in Senegal are so limited.

33 M Baldwin-Edwards, 'The Emerging European Immigration Regime: Some reflections on implications for Southern Europe', Journal of Common Market Studies, vol. 35, no. 4, 1997, pp. 497-519, p. 506.

34 C A Babou, Fighting the Greater Jihad: Amadu Bamba and the founding of the Muridiyya of Senegal, 1853-1913, Ohio University Press, Athens, 2007; J Copans, Les Marabouts de l'Arachide: La confrérie mouride et les paysans de Sénégal, L'Harmattan, Paris, 1988; C Coulon, Le Marabout et le Prince: Islam et pouvoir au Sénégal, Éditions Pédone, Paris, 1981; D B Cruise O'Brien, Saints and Politicians: Essays on the organisation of a Senegalese peasant society, Cambridge University Press, Cambridge, 1975; M Diouf, 'The Senegalese Murid Trade Diaspora and the Making of a Vernacular Cosmopolitanism', Public Culture, vol. 12, no. 3, 2000, pp. 679-702; V Ebin, 'A la Recherche de Nouveaux "Poissons": Stratégies commerciales mourides par temps de crise', Politique Africaine, no. 45, 1992, pp. 86-99.

35 S Bava, 'De la "Baraka aux Affaires": Ethos économico-religieux et transnationalité chez les migrants Sénégalais mourides', Revue Européenne de Migrations Internationales, vol. 19, no. 2, 2003, pp. 69-84; J R Bowen, 'Beyond Migration: Islam as a transnational public space', Journal of Ethnic and Migration Studies, vol. 30, no. 5, 2004, pp. 879-894; V Ebin, 'Making Room versus Creating Space: The construction of spatial categories by itinerant Mouride traders' in B D Metcalf (ed.), Muslim Space in North America and Europe, University of California Press, Berkeley, 1996, pp. $92-108$, p. 98. 
ANTI-TRAFFICKING REVIEW 9 (2017): 77-91

\section{The Age of Securitisation, 2000-present}

Established patterns of intracontinental migration out of Senegal shifted in the early 2000s, after growing xenophobia and regional conflicts broke out. ${ }^{36}$ The two consecutive civil wars in Congo-Brazaville from 1993-1995 and 1997-1999, and the 1999 coup and ensuing civil war in Côte d'Ivoire from 2002 to 2004 heralded a new era of regional unrest. As economic conditions in Senegal, and political situations elsewhere in Africa, deteriorated through the end of the twentieth century, more and more young people came to see Europe as a beacon of fiscal, political, and moral security. While some scholars assert that Senegal continues to send more migrants to other sub-Saharan countries than to the EU, ${ }^{37}$ a more recent analysis reveals that from 1975 to 2008 the number of Senegalese migrating to other African countries decreased steadily, while migration to Europe increased from forty to sixty per cent. ${ }^{38}$ Those who had the good fortune to travel and find work in Europe were idolised in popular stories and proverbs that began circulating widely in Senegal. In the Senegal River valley, sayings include: 'The Haalpulhar [ethnic group] know where they were born but not where they will be buried.' Among the Wolof, it is often said: 'He who does not travel will never know where it is best to live. ${ }^{39}$ For those who lacked family or religious connections to Europe, one of the only alternatives was to attempt to migrate clandestinely.

Between 2005 and 2008, tens of thousands of Senegalese migrants attempted to cross the Atlantic in wooden pirogues heading for the Canary Islands. ${ }^{40}$ In 2006 alone, over 40,000 arrived on the Spanish archipelago. ${ }^{41}$ Departing from Senegalese

36 F Gubert, 'Migrant Remittances and their Impact on Development in the Home Economies: The case of Africa' in Migration, Remittances and Development, OECD Press, Paris, 2005, pp. 41-63, p. 42.

37 J Schoorl et al., Push and Pull Factors of International Migration: A comparative report, EUROSTAT, Brussels, 2000, p. 78.

38 B Schoumaker et al., 'Changing Patterns of African Migration: A comparative analysis', MAFE Working Paper 18, INED, Paris, 2013, p. 12.

39 N Ndiaye, 'Senegalese Values and Other Cultural Push Factors behind Migration and Return', International Commentary, vol. 10, no. 35, 2014, pp. 41-45; S M Tall and A Tandian, 'Regards sur la Migration Irrégulière des Sénégalais: Vouloir faire fortune avec des pirogues de fortune', Research Report, CARIM-AS 2010/50, Robert Schuman Centre for Advanced Studies, European University Institute, Fiesole, 2010.

40 Up until the 1990s, most boat migration to Europe consisted mainly of Moroccans travelling to Spain across the Strait of Gibraltar. At the time, such movements were legal as North African nationals were not required to obtain a visa to enter Spain.

41 P D Fall, Sénégal: Migration, marché de travail et développement, Working Paper, International Labour Organization, Geneva, 2010, p. 31. 
shores en masse and overloaded with passengers, these coastal fishing vessels were often no match for Atlantic swells. An untold number perished in the 1,500kilometre crossing, and of those who did arrive safely, many suffered from dysentery, exposure, and dehydration. At the time, images and stories of these traumatised migrants circulated widely in the press. In an attempt to halt the 'flood' landing on the Canary Islands, the EU expanded maritime patrols off the coast of Senegal, largely through Frontex operations, which effectively crippled the western Atlantic route to Europe. ${ }^{42}$

Again, however, border control directives were not simply European campaigns dictated unilaterally from Brussels. The Senegalese state also had a vested interest in managing migration flows. If claiming one's citizens were part of the nationbuilding project for Senegal in the mid-twentieth century, the state later saw additional fiscal advantages for controlling the movement of its populations in the twenty-first. Senegal conducted a series of important financial and diplomatic accords with the EU and member states which increasingly tied the allocation of development aid to issues of migration control. Bilateral accords were signed with France (2006 and 2008), Spain (2006 and 2007), and Italy (2008), which stipulated the concerted management of migration flows, including the readmission of Senegalese nationals, in exchange for development aid. These agreements signalled a confluence of often contradictory political and economic agendas. On the one hand, southern European countries-Italy and Spain — had been facing enormous political pressure to be the new 'gatekeepers' for Fortress Europe since the 1980s. On the other hand, they needed cheap, often informal migrant labour from the developing world in order to keep their economies running. For this reason, their own immigration policies were often revised with 'dizzying frequency'. ${ }^{43}$

At the same time, these accords also signalled how Senegal was able to deftly mobilise its skills as a 'flexible gatekeeper' on the global stage in order to consolidate power at home. ${ }^{44}$ In regulating migration to Europe in exchange for development

42 Created in 2004, Frontex is the external border management arm of the European Union and has played a major role in crippling clandestine naval routes to Europe by both stopping journeys before they begin in Senegal and by policing the North African coast and the Mediterranean Sea before arrival at their destination. Like Frontex, Spain's Sistema Integrado de Vigilancia Exterior (SIVE) has been another effective border control mechanism. By positioning highly sophisticated surveillance technologies off the Spanish coast, boats were detected and intercepted earlier and thus fewer pirogues were able to make it to European shores. See: J Carling, 'The Merits and Limitations of Spain's High-tech Border Control', Migration Information Source, 7 June 2007, retrieved 8 August 2017, http://www.migrationpolicy.org/ article/merits-and-limitations-spains-high-tech-border-control.

43 Calavita, Immigrants at the Margins, p. 5.

44 F Cooper, Africa Since 1940: The past of the present, Cambridge University Press, Cambridge, 2002, p. 180. 
aid, the Senegalese state has been able 'to sit astride the interface between [its] territory and the rest of the world, collecting and distributing resources that derived from the gate itself ${ }^{45}$ By managing the circulation of its citizens, and directly benefitting from their expulsions, the Senegalese state was able to extract rents not as its citizens left the gate, but as they re-entered it.

Though many state officials, as well as some scholars, optimistically declared in 2009 that boat migration out of Senegal was over, what happened was that rather than stopping migration, patrols simply redirected it. As one repatriated boat migrant in Senegal put it to me, 'With Frontex, migration just moves elsewhere."46 From the moment that Frontex implemented Operation Hera in 2005, migratory routes began shifting overland to journeys across the Sahara to North Africa where, it was rumoured, one could buy passage across the Mediterranean from departure points in Libya. In this way, border controls can actually create what Martin Lemberg-Pedersen calls 'border-induced displacement'. ${ }^{47}$ When the West African route was shut down, migrants already on the move re-directed their transit across the Sahara. For Lemberg-Pedersen, contemporary borders 'do not preempt migration by halting it at fixed points... [Rather, they] transform migration into... border-induced displacement. ${ }^{38}$ Rather than stopping movement, border securitisation, not presumed 'slave traders', forces prospective Senegalese and other West African migrants to take more circuitous and thus more dangerous routes.

\section{Conclusion}

Senegalese people have been migrating for centuries, but for them, the condition of 'irregularity' is a very recent political construction. ${ }^{49}$ In the twentieth century, French worker recruitment programmes actively courted Senegalese labourers throughout the post-war period. Prior to 1986 when France began requiring entry visas for Senegalese nationals, ${ }^{50}$ 'irregular' Senegalese migration was practically and conceptually 'non-existent'. ${ }^{51}$ Migration out of Senegal has a long and profound

$45 \quad$ Ibid., p. 157.

46 Personal interview, Dakar, Senegal, 2013.

47 M Lemberg-Pedersen, 'Effective Protection or Effective Combat? EU border control and North Africa' in P Gaibazzi, A Bellagamba, and S Dünnwald (eds.), EurAfrican Borders and Migration Management: Political cultures, contested spaces, and ordinary lives, Palgrave Macmillan, New York, 2017, pp. 29-61, p. 54.

48 Lemberg-Pedersen, p. 55.

49 K Calavita, 'Immigration, Law, and Marginalization in a Global Economy: Notes from Spain', Law and Society Review, vol. 32, no. 3, 1998, pp. 529-566; N De Genova, 'Migrant "Illegality" and Deportability in Everyday Life', Annual Review of Anthropology, vol. 31, 2002, pp. 419-447.

50 Vickstrom, p. 1067.

51 Beauchemin et al., p. 23. 
history, and it is recent policies that have effectively rendered such movements, and the people who undertake them, illegal, and thus more vulnerable to exploitation.

Despite their 'illegality', Senegalese migrants were able to use their personal networks to access facilitators whom they knew and could trust in the mid-2000s. Though such journeys to the Canary Islands were sometimes tragic, migrants often knew their facilitators and boat captains first-hand and could trust that they operated within the same social universe. After Frontex, their journeys traversed more socially remote geographies through the Sahara, which meant they had to rely on people with whom they were less familiar, and who could potentially take advantage of them without recourse to social protections.

With this history in mind, what does it mean to call migration facilitators 'modernday slave traders'? Is this an accurate assessment? I argue that 'slavery' is not an accurate term to characterise Senegalese migrants who engage in mobility; for them it is part of a long-standing historical and religious practice. Though they do face increasing exploitation along their journeys to Europe, such as being kidnapped, being held for ransom, or literally being sold by depraved people, this development is due to the fact that border securitisation has made safe entry an impossibility for most. In addition, marking African migrants as 'slaves' further reinforces a racial calculus that sees black Africans as inferior and thus necessarily subject to enslavement.

Interestingly, though the language of migration control in the early 2000s insinuated a link between migration and terrorism, today what we see is an increasing victimisation of the migrant subject. As such, the blame is often levelled against migration facilitators, who allegedly use and abuse their human 'cargo' for quick profits. It has become common in media and policy reports to suggest that irregular migrants the world over are manipulated into departure by greedy and unscrupulous human smugglers who do not fully disclose the dangers of passage, and who take advantage of passive or gullible migrants. Consequently, Europe's mission to police its borders becomes a humanitarian project to 'protect' the vulnerable migrant.

Along with EUNAVFOR-MED's Operation Sophia, which seeks to dismantle the 'business model' of migration facilitation, just last year EUROPOL launched the European Migrant Smuggling Center in an effort to '[tackle] the sophisticated international... smuggling networks... that exploit the desperation and vulnerability of migrants. ${ }^{52}$ And the mission is vast. Tracking down and immobilising the '40,000 individual smugglers', ${ }^{53}$ is not only practically ambitious; it also frames

52 EUROPOL, 'Migrant Smuggling in the EU', EUROPOL Public Information Report, 2016, p. 2. See also: Europol, 'Europol Launches the European Migrant Smuggling Centre', 22 February 2016, https://www.europol.europa.eu/content/ EMSC_launch.

53 Ibid., p. 7. 
intervention as a humanitarian response. Playing on the 'care and control duality of humanitarianism, ${ }^{54}$ police interventions 'control' the national borders while 'caring' for the vulnerable migrant who is presumably exploited by criminal thugs. Such discourses do not merely license restriction; they produce truths about the way migration works. In a rather simplistic arithmetic, stopping the smuggler stops the migrant from heading down a dangerous path filled with thieves, extortionists, rapists, drug lords, prostitution kingpins, violent murderers, and 'slave traders'. Increased military patrols, then, are presumably mobilised in the migrant's best interest. And yet migration facilitation is not a result of criminality, but is the consequence of increasingly limited options for legal mobility among populations for whom migration is a culturally meaningful and long-standing historical practice.

Today, Senegalese migration across the Mediterranean is far from over. It is at the front of international debates on border control, humanitarian intervention, and national sovereignty. The Mediterranean Sea has become both an artery and a graveyard for many departing the shores of North Africa in search of a better life. In 2016, over 181,000 migrants arrived in Italy, most of whom were sub-Saharan Africans. ${ }^{55}$ And though outnumbered by Nigerian and Eritrean citizens, Senegalese migrants are among the top ten nationalities to arrive in Italy. ${ }^{56}$ Such numbers tend to flash across television screens and newspaper headlines in a way that reinforces the sense that such migrations are coming 'out of nowhere', and that they are criminally motivated. But news cycles tend to forget previous migrations and the confluence of factors that inspired and shaped them. For Senegalese migrants, the Mediterranean route is but the newest path in a long line of trajectories that have been shifting across land and water for years. In the final analysis, higher border security generally correlates with higher potential for exploitation. Such an assessement disrupts the idea that migrants are victims to depraved and immoral 'slave traders'. Rather, Senegalese migrants are continuing to adapt to increasingly securitised borders as a way to survive.

54 P Pallister-Wilkins, 'The Humanitarian Politics of European Border Policing: Frontex and border police in Evros', International Political Sociology, vol. 9, issue 1, 2015, pp. 53-69, p. 54.

55 United Nations High Commissioner for Refugees, Mediterranean Situation, http:// data.unhcr.org/mediterranean/country.php?id=105.

56 Ibid. 
Stephanie Maher is a postdoctoral fellow at the African Center for Migration and Society (ACMS) at the University of the Witwatersrand in Johannesburg, South Africa. She has conducted ethnographic research on clandestine migration, religious aspiration, and forced repatriation in Senegal (2008-2015), and received her Ph.D. in Cultural Anthropology at the University of Washington in 2015. Building on her previous work with West African migrants, her current research examines the extent to which immigrants and refugees in South African townships use their religious affiliations to access resources such as housing and employment, and how faith-based organisations constitute a new form of political authority in urban South Africa. Email: stephanie.maher@wits.ac.za 


\title{
'Shock and Awe': A critique of the Ghana-centric child trafficking discourse
}

\author{
Samuel Okyere
}

\section{Abstract}

This paper is a critique of the dominant anti-trafficking discourse and activism in Ghana. It argues that the discourse grossly underplays the role of external forces in shaping the conditions underpinning children's labour mobility in the past and the hardships underpinning the phenomenon today. In place of critical analysis and understanding, anti-child-trafficking campaigns employ melodramatic 'shock and awe' tactics and a tendency to blame local culture or traditions for activists' claims of 'pervasive' child trafficking in the country. The paper suggests that dominant anti-trafficking discourse and activism in Ghana thus reinvigorate historic and persistent external causal agents of inequality which drive Ghanaian children's labour mobility today. The paper demonstrates this problem and offers correctives to it.

Keywords: child trafficking, anti-trafficking, Ghana, history, Volta lake, Africa, fishing

Please cite this article as: S Okyere, “'Shock and Awe": A critique of the Ghanacentric child trafficking discourse', Anti-Trafficking Review, issue 9, 2017, pp. 92105, www.antitraffickingreview.org

\section{Introduction}

Over the past two decades, there has been a radical shift in the field of child rights advocacy in Ghana, marked primarily by a proliferation of organisations and actors coalesced around the issue of child trafficking or 'modern slavery' as some characterise it. The child trafficking or 'child slavery' problem is said to be prevalent nationwide. The proliferation of anti-trafficking organisations and intensification of their campaigns has had minimal impact on the problem. After almost two decades of campaigns, advocates insist that the situation is in fact deteriorating. Some have

This is an open-access article distributed under the terms of the Creative Commons Attribution License (CC-BY). Under the CC-BY license, the public is free to share, adapt, and make commercial use of the work. Users must always give proper attribution to the authors and the Anti-Trafficking Review. 
likened it to an 'epidemic"1 while others describe Ghana as 'a country where modern day slavery is rampant'. ${ }^{2}$ These views are reflected in the recent United States Trafficking in Persons (TIP) Report rankings. In 2003 and 2004 Ghana was given a Tier 1 rating. ${ }^{3}$ The country was deemed fully compliant with 'the minimum standards for the elimination of trafficking', and continued to 'excel at victim protection, particularly in regard to repatriating trafficked children and providing assistance to their families'. ${ }^{4}$ From 2005 onwards, alongside the proliferation of anti-trafficking organisations and intensification of their initiatives, Ghana has only managed a Tier 2 rating. Indeed, since 2015, the country has fallen further in the rankings; it is currently on the Tier 2 Watch List as a country that is no longer compliant with the minimum standards.

It seems paradoxical that the 'trafficking problem' is deemed to be worsening even as domestic anti-trafficking initiatives have been amplified by governmental and international institutions, NGOs, businesses, churches and other actors. ${ }^{5}$ This observation adds to other concerns expressed about the anti-trafficking discourse in Ghana. Findings from several studies call into question the veracity of claims of widespread child trafficking, as the phenomenon of independent child migration is often misconstrued. ${ }^{6}$ It has also been argued that the emphasis on 'child trafficking' renders invisible the diverse forms of children's mobility in the country. ${ }^{7}$

1 O Agyemang, 'Project Update for July to September 2013', Cheerful Hearts Foundation, 14 October 2013, retrieved 10 July 2017, https:// www.globalgiving.org/projects/rescue-100-children-from-child-labour-in-ghana/ reports $/$ ?subid $=36552$.

2 B Weiss, 'Government and Civil Society Unite Against Ghana Child Trafficking', Huffington Post, 2 August 2016, retrieved 10 July 2017, http:// www.huffingtonpost.com/free-the-slaves/government-and-civil-soci_b_ 11294410.html.

See: US Department of State, Trafficking in Persons Report, 2003, 2004.

Ibid., 2004, p. 57.

5 B N Lawrance, "From Child Labor "Problem" to Human Trafficking "Crisis": Child advocacy and anti-trafficking legislation in Ghana', International Labour and WorkingClass History, vol. 78, issue 1, 2010, pp. 63-88.

6 See: S O Kwankye, J K Anarfi, C A Tagoe and A Castaldo, 'Independent NorthSouth Child Migration in Ghana: The decision-making process', Working Paper T-29, Sussex Migration Centre, 2009; G B Abdul-Korah, “Now if You Have Only Sons You are Dead": Migration, gender and family economy in twentieth century north-western Ghana', Journal of Asian and African Studies, vol. 46, no. 4, 2011, pp. 390-403; I Hashim and D Thorsen, Child Migration in Africa, The Nordic Africa Institute, Uppsala, Zed Books, London and New York, 2011.

7 A Whitehead, I M Hashim, and V Iversen, 'Child Migration, Child Agency and Inter-generational Relations in Africa and South Asia', Working Paper T24, Research Centre on Migration, Globalization and Poverty, University of Sussex, Brighton, 2007. 
An additional critique presented by this paper is that the discourse deflects attention from the historic and persistent structures of inequality in the global political and economic order which largely underpin children's labour mobility in Ghana today. I argue that this deficiency presents an obstacle to the formulation of comprehensive solutions to problematic aspects of such movement among other insecurities confronting children and families. The next section of the paper outlines the salient features of the dominant Ghana-centric child trafficking discourse, showing the lack of historicity in anti-trafficking advocates' taxonomy of the causes, scale and features of child trafficking. Next, I present historical material omitted from these diagnoses. Finally, in the discussion and conclusion section, I consider the reasons for this omission, and how the deficit impacts on the characterisation, understanding and responses to child trafficking in Ghana

\section{Overview of the Child Trafficking Discourse in Ghana}

Although many aspects of the Ghana-centric child trafficking discourse are informed by the country's internal socio-cultural, economic and political dynamics, they are firmly rooted in the broader international legislative framework and discourse on trafficking. Ghana's Human Trafficking Act (2005), for example, has been described as a carbon copy of the Protocol to Prevent, Suppress and Punish Trafficking in Persons, Especially Women and Children (2000) (hereafter referred to as the Trafficking Protocol). ${ }^{8}$ In keeping with Article 3(a) of the Trafficking Protocol, Section 1(1) of the Ghana Human Trafficking Act also defines human trafficking as 'the recruitment, transportation, transfer, harbouring, trading or receipt of persons within and across national borders by (a) the use of threats, force or other forms of coercion, abduction, fraud, deception, the abuse of power or exploitation of vulnerability, or (b) giving or receiving payments and benefits to achieve consent'.

Another common thread between the Trafficking Protocol and the Ghana Human Trafficking Act is considerations around consent in identifying a victim of trafficking. The consent of an adult to her or his movement and intended or actual exploitation is deemed immaterial where threat, force, coercion, abduction, fraud, deception and other 'unfree' means were used to obtain it. Implicit in this formulation is an acknowledgement that adults may and do 'freely' consent to being recruited, transported, harboured or received for practices which could be

\footnotetext{
See: M Sertich and M Meemskerk, 'Ghana's Human Trafficking Act: Successes and shortcomings in six years of implementation', Human Rights Brief, vol. 19, issue 1, 2011, pp. 2-7; S Bukari, Parts Unknown: A critical exploration of fishers' social constructs of child labour in Ghana, Doctoral thesis, University of Sussex, 2016, retrieved 2 July 2017, http://sro.sussex.ac.uk/61740/.
} 
deemed exploitative. The cases of overseas domestic workers and other migrant labourers toiling in appalling and exploitative conditions in different sectors across the world exemplify this point. ${ }^{9}$ In the case of children however, consent is deemed irrelevant both in terms of movement and any 'exploitative' outcome from it, ${ }^{10}$ and the means do not need to be present to establish the crime. Likewise, the Ghana Human Trafficking Act states: 'Where children are trafficked, the consent of the child, parents or guardian of the child cannot be used as a defence in prosecution under this Act, regardless of whether or not there is evidence of abuse of power, fraud or deception on the part of the trafficker or whether the vulnerability of the child was taken advantage of.'

O'Connell Davidson's critical observation about the Trafficking Protocol's vagueness on what constitutes exploitation ${ }^{11}$ also applies to the Ghana Human Trafficking Act. For sure, Article 3(a) of the Trafficking Protocol states that, "Exploitation shall include, at a minimum, the exploitation of the prostitution of others or other forms of sexual exploitation, forced labour or services, slavery or practices similar to slavery, servitude or the removal of organs.' However, this accompaniment still fails to offer a precise definition or explanation of exploitation, just as the Ghana Human Trafficking Act also outlines a 'minimum' yardstick for exploitation without a ceiling or, better still, a precise definition for it. Both legislative frameworks therefore suggest that any movement of a child (defined by both the Trafficking Protocol and the Ghana Children's Act 1998 as any person under eighteen years of age) which results in a situation interpreted by individuals or groups as 'exploitative', can be labelled as 'child trafficking'. Identification of child trafficking is therefore largely reliant on what actors deem to be 'child exploitation' based on their personal, cultural and political morals or value judgements. This is often the case in the Ghana-centric child trafficking discourse.

This discourse emerged around the late 1990s and gained much traction from the early 2000s. One of its precursors was the International Labour Organization's (ILO) Convention C182 on the Worst Forms of Child Labour (hereafter, Convention 182) which had entered into force around that same period. Convention

9 For a discussion of such examples, see: B Anderson, 'Migration, Immigration Controls and the Fashioning of Precarious Workers', Work, Employment \& Society, vol. 24, no. 10, 2010, p. 303; and D Demetriou, “Tied Visas” and Inadequate Labour Protections: A formula for abuse and exploitation of migrant domestic workers in the United Kingdom', Anti-Trafficking Review, issue 5, 2015, pp. 69-88.

10 See: International Labour Organization, Meeting the Challenge: Proven practices for buman trafficking prevention in the Greater Mekong sub-region, Mekong Sub-regional Project to Combat Trafficking in Children and Women, International Programme on the Elimination of Child Labour, Bangkok, 2008.

11 J O'Connell Davidson, Modern Slavery: The margins of freedom, Palgrave Macmillan, London, 2015. 
182 heralded a raft of national, regional and international interventions to end the 'worst forms' of child labour as well as 'child trafficking' as outlined in Article 3. Children's work in the West African cocoa sector was particularly high on this agenda following a series of media reports in the early 2000s which suggested that 'hazardous child labour', 'child bondage', 'child slavery' and 'child trafficking' were pervasive in this sector. ${ }^{12}$ Concurrently, the Trafficking Protocol had also been passed, and both domestic and international child rights actors increasingly repositioned their preventative work against the worst forms of child labour under the ambit of child trafficking. As Lawrance similarly observes, from a 'problem' of the worst forms of child labour in the early 1990s, child rights advocates in Ghana now principally talk of the 'crises' or 'scandal' of 'child trafficking.' ${ }^{13}$

The metamorphosis occurred for two principle reasons. First, worst forms of child labour campaigns fell on unsympathetic ears and were also mired in disagreements. The local, national, and international actors involved had divergent messages about the nature and permissibility of children's work in agriculture and other areas of Ghanaian society. ${ }^{14}$ Second, there was a long-existing and well-known practice of child and youth labour mobility in Ghana. The intractable controversy encountered by child labour preventative campaigns coupled with existence of children's labour mobility and the relatively low bar set by the Ghana Human Trafficking Act for defining child trafficking collectively catalysed the reconfiguration of the child labour discourse using the language of trafficking.

Since 2000, the Ghanaian child rights sector has witnessed a proliferation of individuals and organisations which employ child trafficking as a catch-all term for child labour, forced labour, child migration, child prostitution, child marriage and other child rights foci. A related trend which exemplifies critiques by Musto, ${ }^{15}$ O'Connell Davidson, ${ }^{16}$ and Chuang ${ }^{17}$ is the conflation of 'trafficking', 'forced

12 For a discussion of these news items, see for example: C Lamb, 'The Child Slaves of the Ivory Coast-Bought and sold for as little as $t_{,} 40$ ', The Telegraph, 27 April 2001; H Hawksley, 'Meeting the "Chocolate Slaves", BBC, 13 June 2002, retrieved 31 May 2017, http://news.bbc.co.uk/1/hi/world/africa/2042474.stm.

13 Lawrance, p. 74.

${ }^{14}$ See: G M Hilson, 'Child Labour in African Artisanal Mining Communities: Experiences from northern Ghana', Development and Change, vol. 41, 2010, pp. 445473; Lawrance, p. 64

15 J L Musto, 'What's in a Name?: Conflations and contradictions in contemporary U.S. discourses of human trafficking', Women's Studies International Forum, vol. 32, no. 4, 2009, pp. 281-287.

16 J O'Connell Davidson, 'New Slavery, Old Binaries: Human trafficking and the borders of "freedom"', Global Networks, vol. 10, issue 2, pp. 244-261, 2010.

17 J Chuang, "The Challenges and Perils of Reframing Trafficking as "Modern-Day Slavery", Anti-Trafficking Review, issue 5, 2015, pp. 146-149. 
labour', and 'modern slavery' in the discourse. For instance, in an anti-trafficking piece for the Daily Graphic, Ghana's leading newspaper, Boyle argues that 'slavery has a different name today — human trafficking, ${ }^{18}$ The child trafficking problem is said to be ubiquitous nationwide across a variety of sectors: 'Both boys and girls are trafficked within the borders of Ghana for forced labour within the fishing and agriculture, for street hawking, forced begging, religious rites, mining, stone quarrying, porters etc. ${ }^{, 19}$ Although studies of the country's north-south labour migration of children and youth indicate that many of these young people migrate independently or with siblings and peers, Hazelwood suggests that this is another area where 'trafficking occurs regularly'. ${ }^{20}$ 'Recruiters violate Ghana's Human Trafficking Act by falsely promising the girls a better life in the south through providing schooling, shelter, food, and clothing. While parents may consent to the migration, the Act provides that consent remains irrelevant when the practice involves children. Therefore, parental consent or the girls' willingness to work does not negate the illegality of the migration', she argues. ${ }^{21}$

The fishing industry along the Lake Volta is at the top of the discourse's iconography of child trafficking and child slavery in Ghana. It is difficult to overestimate the volume of research, reports, campaigns, and other initiatives focussed on this area. ${ }^{22}$ A reliable estimate of the actual number of purported victims of child

18 L Boyle, 'Child Trafficking: A symbol of poverty and vulnerability', Graphic Online, 20 December 2013, retrieved 10 July 2017, http://www.graphic.com.gh/features/ opinion/child-trafficking-a-symbol-of-poverty-and-vulnerability.html.

19 C Wenngren, Causes of Child Trafficking: A case study of Ghana, Lund University, 2011, p. 16, retrieved 10 July 2017, http://lup.lub.lu.se/luur/download?func= downloadFile\&recordOId=1968825\&fileOId=1968831.

20 K Hazelwood, 'Ghana's Invisible Girls: The Child-Kayayei business and its violation of domestic and international child labour laws', Jouranl of Global Justice and Public Policy, vol. 1, issue 77, 2011, pp. 77-159, p. 96.

21 Ibid.

22 See the following, for example: E Taylor, 'Freeing the Child Slaves of Volta Lake', Modern Ghana, 13 March 2003, retrieved 10 July 2017, https:// www.modernghana.com/news/111880/freeing-the-child-slaves-of-voltalake.html; H K Golo, The Interface of Poverty, Livelihoods, Coping/Survival Strategies and Child Trafficking in Rural Coastal Fishing Communities of Ghana, Dissertation, University of Vienna, 2012, retrieved 5 July 2017, http://othes.univie.ac.at/ 24733/; K Bales, Understanding Global Slavery: A Reader, University of California, Berkeley, 2005; International Justice Mission, Child Trafficking into Forced Labour on Lake Volta, Ghana: A mixed-methods assessment, IJM, Accra, 2016, retrieved 1 May 2017, http://challengingheights.org/wp-content/uploads/2014/11/ IJM_Ghana_FINAL_single_revised_5.22.pdf; L Agbenya, Child Labour Trafficking in the Lake Volta Fishery in Ghana: A case of Ogetse in the Krachi West District of the Volta region, Master's thesis in International Fisheries Management at the Department of Social and Marketing Studies, Norwegian College of Fishery Science, University 
trafficking in this area is impossible to attain; figures ranging from a couple of thousands to tens of thousands have been cited by anti-trafficking campaigners. The anti-trafficking coalition is nonetheless unified on the view that 'significant levels of child trafficking and slavery-like conditions' exist in communities located around the lake, according to the NGO Free The Slaves, ${ }^{23}$ and that cases of child trafficking and forced labour are 'common' and 'violent', as asserted by the International Justice Mission (IJM). ${ }^{24}$

The majority of children working in the Lake Volta fishing industry are said to be ten years old or younger. ${ }^{25}$ A BBC documentary on this issue in February $2017^{26}$ suggested that children are simply given to traffickers or 'slave masters' by parents who are unable to cater for them, or sold for as little as $f, 12$, according to Left. ${ }^{27}$ The children are said to labour seven days a week from 4 am, regularly working for 15 hours daily. ${ }^{28}$ Girls de-scale fish, serve as 'sex slaves' and perform other domestic chores, while boys mend, cast and hoist nets. ${ }^{29}$ Following a study commissioned to 'harvest the memories and experiences of children who have been rescued from slavery in fishing communities along Lake Volta', Challenging Heights, an organisation which also plays a prominent role in the Ghanaian anti-trafficking discourse, adds that 'enslaved children' are also often forced into marriage. ${ }^{30}$ These

of Tromsø, 2009; S E Hamenoo and C A Sottie, 'Stories from Lake Volta: The lived experiences of trafficked children in Ghana', Child Abuse and Neglect, vol. 40, 2015, pp. 103-112; J K Annan, 'Eliminating Child Slavery on Lake Volta', Graphic Online, 31 March 2016, retrieved 1 July 2017, http://www.graphic.com.gh/features/ opinion/eliminating-child-slavery-on-lake-volta.html.

23 Free the Slaves, 'New Research Indicates High Prevalence of Child Trafficking and Slavery-Like Conditions in Ghana Fishing Villages', 28 February 2017, retrieved 10 July 2017, http://www.freetheslaves.net/new-research-indicates-high-prevalenceof-child-trafficking-and-slavery-like-conditions-in-ghana-fishing-villages/.

24 International Justice Mission, 2016.

25 Ibid., p. 9.

26 BBC, 'Ghana's Child Labourers', BBC World News, 2017, retrieved 10 July 2017, http://www.bbc.co.uk/programmes/n3ct0bxk.

27 S Left, 'Sons for Sale', The Guardian, 22 March 2007, retrieved 10 July 2017, https://www.theguardian.com/world/2007/mar/22/sarahleft.

28 G Freduah, Poverty Mitigation and Wealth Creation through Artisanal Fisheries in Dremeni Area at Volta Lake, Ghana, Master of Philosophy Degree in Resources and Human Adaptations, Department of Geography, University of Bergen, Norway, 2008, p. 83.

29 See: Boyle, 2013; International Justice Mission, 2016.

30 K Tsekpo, A Afram, E S Boateng and C Sefa-Nyarko, Analysing the Experiences of Children who are Thought to Have Witnessed or Undergone Child Forced Early Marriage in the Volta Lake Communities of Ghana, Challenging Heights, 2016, retrieved 2 May 2017, http://challengingheights.org/wp-content/uploads/2017/01/CFEM-inFishing-Industry-on-Lake-Volta-Report.pdf. 
forced marriages to 'another child slave, or to the slave master or to a member of the slave master's family' are in order to keep child slaves in their master's control when they become adults, or simply to 'keep older boys in their employment through sexual rewards and marriage', adds the IJM. Publicity materials portraying these issues and other anti-trafficking advocacy are awash with images of 'rescued slaves', harrowing narratives by 'slavery survivors' and depictions of children toiling under great strain on boats, at mining sites and elsewhere. ${ }^{31}$

The discourse offers a variety of explanations for the existence of child trafficking in Ghana. Some have suggested that Ghanaian culture 'provides a conducive socioeconomic environment that benefits and nurtures the trafficking phenomenon'. ${ }^{32}$ The practice of fostering or child placement is said to be at the root of modern-day trafficking in West Africa as a whole, according to the Walk Free Foundation. ${ }^{33}$ Others point to poverty and socio-economic deprivation in the decision. ${ }^{34}$ As Golo argues, 'Out of poverty, parents become comfortable with sending their children into bonded labour as the shortest means of solving their own economic and social hardships. ${ }^{35}$ The causes ascribed by the discourse are far too many to be rehearsed here, but David Kofi Awusi, advocacy manager of Challenging Heights, has summed them up as follows: 'Through research and over 10 years of operations, the organisation has discovered that child trafficking in Ghana is caused by poverty, ignorance, poor parental care and lack of support for children. Furthermore, weak political commitment reflected in inadequate allocation of resources to combat human trafficking and weak enforcement of laws and implementation of national policies and plans, also contribute to the problem. ${ }^{36}$

It should be noted that while the Ghana-centric child trafficking discourse largely agrees on all the issues discussed in this section, the field is not necessarily concordant. For instance, an ILO study of child labour in fishing on the Lake Volta casts doubts on the startling aspects of the discourse. ${ }^{37}$ The ILO study confirms the involvement of children in the sector under dangerous and exploitative conditions.

31 See for instance: Where we Work: Ghana, Free the Slaves, http:// www.freetheslaves.net/where-we-work/ghana/.

32 Wenngren, p. 60.

33 Walk Free Foundation, Global Slavery Index, Hope for Children Organization Australia Ltd., 2014.

34 Agbenya, p. 56.

35 H K Golo, Poverty and Child Trafficking in Ghana: A study of the fishing sector, M.A. thesis, 2005, p. vi, retrieved 7 July 2017, http://bit.ly/2v37beN.

36 D K Awusi, 'Let's Eliminate Child Ttrafficking in Ghana', Graphic Online, 4 September 2015, retrieved 10 July 2017, http://www.graphic.com.gh/features/ features/let-s-eliminate-child-trafficking-in-ghana.html (emphasis added).

37 International Labour Organization, Analytical Study on Child Labour In Lake Volta Fishing in Ghana, ILO, Geneva, 2013. 
However, claims of pervasive child slavery, child marriage and others which continue to dominate the discourse were not corroborated: "The fieldwork did not identify any significant number of children as sex slaves who are in fishing. An overwhelming majority of respondents of 97 per cent said no such sex slaves are engaged in fishing. Likewise, the investigations into child servitude revealed that no children in servitude (97 per cent) are in fishing. Respondents could not also admit the prevalence of children under early/forced marriages being engaged in fishing. A majority of 97 per cent of respondents said there are no children in that category engaged in fishing activities on the lake. ${ }^{38}$

The discourse is also increasingly confronted by the same problems which dogged the child labour campaigns in the late 1990s and early 2000s. Some communities targeted by anti-trafficking campaigns and 'rescue' operations have levelled various allegations against these activities. The most recent case concerns the IJM. In June 2017, Betty Nana Efua Crosby Mensah, Member of Parliament (MP) for Afram Plains North in the Eastern Region delivered a statement in the Ghanaian Parliament calling for the return of children allegedly abducted by the IJM staff under the 'misconception of rescuing them from child labour/child trafficking'. ${ }^{39}$ The MP argued that organisations such as the IJM erroneously consider children in the area to be victims of child labour and trafficking because they 'never consulted with stakeholders, traditional rulers or opinion leaders to really understand the cultural setting of the Afram Plains area'. This issue of ill-informed child rights interventions by some NGOs and activists has also been highlighted by other scholars in the context of West Africa. ${ }^{40}$

\section{North-South Children Migration in Ghana: A brief history}

As mentioned in the previous section, there is a long history of youth and children's labour migration in Ghana. To a considerable extent, this migratory practice, especially among youth from the country's three northern regions, has been shaped by British colonial expansion and contrivance. From 1900 to 1940, gold mining in the then British Gold Coast colony was largely non-industrialised. ${ }^{41}$ Manual labour was therefore critical to the survival of the developing British colonial mining industry. However, due to dangerous working conditions, exploitative wages and general distaste for underground work, indigenes of areas where the mines were located

$38 \quad$ Ibid., p. 37.

39 See report on this story by F Shaibu and D Adogla-Bessa, 'Return Our Children, You Abducted - MP tells NGO', Ghananewspage.com, 13 June 2017, retrieved 10 July 2017, http://ghananewspage.com/?p=3100.

40 See for the most recent critique: N Howard, Child Trafficking, Youth Mobility and the Politics of Protection, Palgrave Macmillan, London, 2017.

41 Hilson. 
refused to take up jobs in the sector. ${ }^{42}$ Facing economic ruin, British mining company owners placed pressure on the British government and colonial administrators to institute a range of coercive mechanisms to compel people to work in the mines. As Thomas ${ }^{43}$ notes in a more extensive discussion of these measures, the primary measure was the systematic exclusion of the northern half of the country from the construction of roads, schools, hospitals, factories and all other developmental projects in order to force northerners to move down south to work in the mines.

The effect of this 'scorched-earth' developmental deprivation policy (and the resultant droves of emigration from northern Ghana) is a cycle of poverty, deprivation and underdevelopment which has been difficult to reverse sixty years after independence. The persistence of underdevelopment and deprivation in the northern half of the country has also been due to International Monetary Fund (IMF) and World Bank-led economic reforms instituted in the country in the early 1980s and still ongoing. ${ }^{44}$ A critical aspect of these reforms was the removal of subsidies and agricultural products under IMF structural adjustment conditionalities. These hit the three northern regions, the Volta region and the Central region the hardest as subsistence agriculture and fishing were the mainstay of many living here. ${ }^{45}$ A recent report by ActionAid on the impact of the IMF's interventions in Ghana pointedly states that its financial reforms often require the government to reduce spending on health, education, and development: 'the IMF in effect demands the poor in Ghana to have lower standard of living. ${ }^{46}$

It is instructive to note that the three northern regions, Volta region and the central region, where anti-trafficking campaigners suggest that child trafficking is most pervasive, are also among the areas worst affected by structural adjustment and other economic reforms in Ghana. Therefore, as Golo argues, the surge in inclusion of children in fishing on the Lake Volta cannot be understood without reference to the twenty years of structural adjustment experienced by Ghana. ${ }^{47}$

42 K O Akurang-Parry, 'The Loads are Heavier than Usual: Forced labour by women and children in the Central Province, Gold Coast (Colonial Ghana), CA. 19001940', African Economic History, no. 30, 2002, pp. 31-51.

43 R G Thomas, 'Forced Labour in British West Africa: The case of the northern territories of the Gold Coast 1906-1927', Journal of African History, vol. 14, no. 1, 1973, pp. $79-103$.

44 O Abena and I Aryee, 'Investigating Chronic Poverty in West Africa', CPRC Working Paper No. 28, 2003.

45 See for a more detailed discussion: Golo, 2005; A Whitehead, I M Hashim and V Iversen, 2007

46 ActionAid Ghana, Implications of IMF Loans and Conditionalities on the Poor and Vulnerable in Ghana, ActionAid, 2010, p. 45, retrieved 23 June 2016, http://bit.ly/ 28Slcqi.

47 Golo, 2005, p. 4. 
Thus, the reference to Ghanaian culture as a causal factor for trafficking suggests a lack of understanding of the historical and persistent external forces of inequality which shape children's labour mobility in Ghana. Elsewhere in the country, economic liberalisation policies have also resulted in widespread dispossession of rural folks of their lands, forcing many children and their families into precarious artisanal gold mining work. ${ }^{48}$ In these cases too, the children's work is what is often held up as the problem that requires elimination as opposed to the factors that have driven them into precarious labour. The discussion and conclusion section which follows explores the reasons for the Ghanaian anti-trafficking coalition's silence on children's participation in exploitative labour as well as the implications of this silence.

\section{Discussion and Conclusion}

The issue of child trafficking has now gained international attention as a 'distinct and egregious violation of children's rights' that needs to be stamped out. ${ }^{49}$ An anti-trafficking coalition has emerged in Ghana in response to this call, asserting that child trafficking and 'child slavery' are rampant in the country. This article argues that while concerns about child rights expressed by these actors are valid, the discourse is deficient because its portrayals and diagnoses lack crucial historical grounding. In the absence of a clear agreement on the number of purported trafficking victims, the discourse conflates distinct children's rights issues to create an impression of widespread 'child trafficking' and 'child slavery'. The coalition's principal modus operandi is the use of emotive language to convey 'shock and awe', or what Lawrance describes as a 'crisis' narrative. ${ }^{50}$ In this sense, the Ghanacentric anti-trafficking narrative is well coordinated with the global anti-trafficking discourse both in terms of legislative framework and the messages they propagate. As other scholars have observed, the global anti-trafficking campaign prioritises 'melodramatics' over complex critical analyses in its advocacy, ${ }^{51}$ in a calculated strategy intended to minimise scrutiny of its messages. ${ }^{52}$

48 S Okyere, 'Are Working Children's Rights and Child Labour Abolition Complementary or Opposing Realms?', International Social Work, vol. 56, issue 1, 2012, pp. 80-91.

49 International Labour Organization, Unbearable to the Human Heart: Child trafficking and action to eliminate it, ILO, Geneva, 2002, p. ix.

50 Lawrance.

51 J L Westwood, The Social Construction of Risk in Child Trafficking Discourses: A study of melodramatic tactics in child trafficking narratives, Doctoral thesis submitted to the University of Central Lancashire, 2012, retrieved 10 July 2017, http:// clok.uclan.ac.uk/3717/3/Westwood $\% 20$ Joanne $\% 20$ Final $\% 20$ eThesis $\% 20$ (Master\%20Copy).pdf; C Vance, 'Innocence and Experience: Melodramatic narratives of sex trafficking and their consequences for law and policy', History of the Present, vol. 2, no. 2, pp. 200-218.

52 J O'Connell Davidson, 'Will the Real Sex Slave Please Stand up?', Feminist Review, vol. 83, issue 1, 2006, pp. 4-22; O’Connell Davidson, 2015. 
The use of shock, melodrama, hyperbole, and accentuation of the most egregious cases to create an impression of 'rampant' child trafficking is detrimental to antitrafficking campaigns. The proliferation of these messages has created the appearance of a moral panic, while campaigners' 'neoliberal turn on traditional African parental ideologies ${ }^{53}$ relating to childhood, children's mobility and other practices also brings them into conflict with local communities. The recent statement in the Ghanaian Parliament denouncing child trafficking 'rescue' operations exemplifies this point. The anti-trafficking coalition's reliance on ideology emanating from international legislative frameworks apparently makes its members so convinced of the rightness of their cause that they have become virtually impervious to alternative suggestions for thinking about the 'problem', including those from the communities or groups on whose behalf they purport to be working. ${ }^{54}$

I agree with Vance that anti-trafficking organisations find it difficult to fit the role of structural adjustment, enforced free-trade policies and other causal factors of human insecurity in the seemingly realist depictions they promote. ${ }^{55} \mathrm{I}$ argue further that omission of these factors and historical analysis in the case of Ghana may also be calculated. The fact is that anti-trafficking organisations and activists in the country and elsewhere are not neutral or disinterested parties in the narratives they present to the public. ${ }^{56}$ They must raise significant sums to pay staff salaries and office costs, publicise their work and undertake campaigns. Many require support from donors, government bodies and politicians for funding, legitimacy and other purposes. Thus, underneath the façade of sheer benevolence and altruism lie deeply personal, material and political interests. To situate the underlying causes of Ghanaian children's labour mobility in the past as well as the present within the context of global political and economic inequality risks criticising and thus undermining major sources of funding and political support. Some of these sources are governments and institutions which are deeply complicit in the creation of historical and persistent socio-economic insecurities in Ghana.

Additionally, anti-trafficking organisations and campaigners in Ghana seem to have constructed an unending, Sisyphean task for themselves. Even as they continuously share news of successful rescues, they also insist that the country's child trafficking problem is worsening rather than improving. The most prominent

\footnotetext{
Lawrance, p. 79.

See Howard, 2017 for expansion of this critique.

Vance, p. 202.

Similar arguments have been made by N Piper, M Segrave and R N Moore, 'Editorial: What's in a Name? Distinguishing forced labour, trafficking and slavery', AntiTrafficking Review, issue 5, pp. 1-9, and also by J L Musto, 'The NGO-ification of the Anti-Trafficking Movement in the US', Wagadu: A journal of transnational women's and gender studies, vol. 5, 2008, pp. 6-20.
} 
and persistent theme in the discourse since its emergence about two decades ago is the argument that Ghana is being overrun by traffickers and victims. I argue that it is not coincidental that the proliferation of anti-trafficking organisations and advocacy in the country has witnessed a concomitant 'worsening' of child trafficking in Ghana, as per the coalition's own analyses and the US TIP rankings. It is possible that mechanisms for identifying trafficking victims may simply have improved or become more sophisticated over this period. However, it could also be deduced that the scale of the problem (and there is a problem) is being exaggerated by antitrafficking campaigners for fundraising and other purposes.

The above has serious potential detrimental impacts on the country at large given the role the discourse plays in shaping measurements and statistics on trafficking in recent years. Trafficking rankings such as the US TIP Report, for example, serve foreign policy agendas including sanctions and penalties against countries with a poor rating. ${ }^{57}$ Following Ghana's fall to the Tier 2 Watch List on the TIP ranking, the United States government has been threatening to punish the country by denying the Ghanaian government access to over USD 500 million in development aid and access to the Millennium Challenge Corporation Compact if Ghana failed to adequately address human trafficking, child labour and 'modern slavery'. ${ }^{58}$ Such sanctions might only worsen the economic situation in a country that is already impoverished and unable to meet the welfare needs of its citizens. Exaggerations in the scale of the problem by anti-trafficking campaigners can therefore inadvertently create conditions which undermine the country's ability to pursue its child rights objectives among national social welfare programmes.

In light of the above, it is strange and alarming that having failed to take on the global structures of inequality which underpin children's rights violations in the country, leading figures of the anti-trafficking coalition in Ghana such as James Kofi Annan, have also written in support of the United States government's threats to impose financial sanctions on Ghana. ${ }^{59}$ Anti-trafficking campaigners

57 See for a related discussion: O Enos, A Call to Review Evaluation Methods in the Trafficking in Persons Report, The Heritage Foundation, 2015, retrieved 10 July 2017, http://www.heritage.org/crime-and-justice/report/call-review-evaluationmethods-the-trafficking-persons-report.

58 See: R Adadevoh, 'Modern Day Slavery Rife in Ghana', CAJ News Africa, 4 July 2016, retrieved 18 May 2017, http://cajnewsafrica.com/2016/07/04/modernday-slavery-rife-in-ghana/; E K Dogbevi, 'Human Trafficking: US warns Ghana could be downgraded, lose millions in aid', Ghana Business News, 30 June 2016, retrieved 18 May 2017, https://www.ghanabusinessnews.com/2016/06/30/ human-trafficking-us-warns-ghana-could-be-downgraded-lose-millions-in-aid/.

59 See: J K Annan, 'When Would Ghana See An End To Human Trafficking? A letter to Oye Lithur', Peace FM, 8 August 2016, retrieved 18 May 2017, http:// www.peacefmonline.com/pages/comment/features/201608/288024.php. 
have unwittingly and in some cases purposefully become complicit in the use of 'anti-trafficking' and 'anti-slavery' concern as another mechanism of coercion and control wielded by relatively richer, powerful states against relatively poorer and weaker ones. Reference to history and more complex analysis of the factors underpinning children's labour mobility can provide correctives for addressing this deficit and also result in more holistic and sustainable solutions than the 'rescue' model which currently dominates the sector.

Samuel Okyere is an Assistant Professor in Sociology and Criminology at the University of Nottingham. He is primarily interested in the use of sociological, anthropological and policy perspectives to address questions on the interplay between rights, power, inequality, domination, class and ethnicity under conditions of globalisation. His current research addresses themes that are of immense significance to contemporary international human rights agendas and goals such as Sustainable Development Goal 8 on decent work for all and Sustainable Development Goal 3 on the promotion of healthy lives and well-being for all at all ages. Dr Okyere is an active participant in international debates on the tensions that arise from the pursuit of universal human rights agendas and the need to recognise and respect differences in socio-cultural norms and values.

Email: Samuel.Okyere@nottingham.ac.uk 

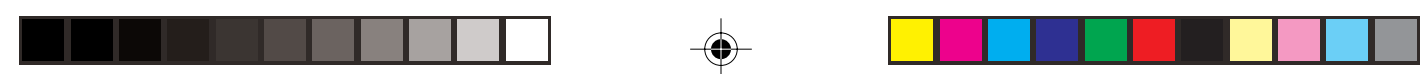

\section{ANTI-TRAFFICKING REVIEW \\ Guidelines for Contributors}

We welcome submissions from a diverse range of actors, including academics, practitioners, trafficked persons and advocates. The Anti-Trafficking Review particularly welcomes contributions from those with direct experiences and insights to share.

The Anti-Trafficking Review is aimed at a wide readership. It therefore encourages submissions that are in clear, jargon-free English with appropriate but not excessive citation.

Articles should be previously unpublished and should not be under consideration for publication elsewhere. All articles go through a rigorous double-blind peer review process.

Please refer to the journal's website (www.antitraffickingreview.org) for the journal's full style guide and guidelines for contributors.

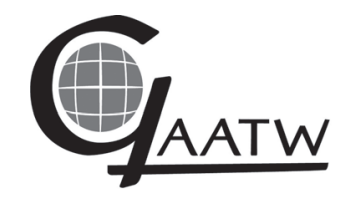

GLOBAL ALLIANCE AGAINST TRAFFIC IN WOMEN P.O. Box 36, Bangkok Noi Post Office 10700 Bangkok, Thailand

Website: www.antitraffickingreview.org 


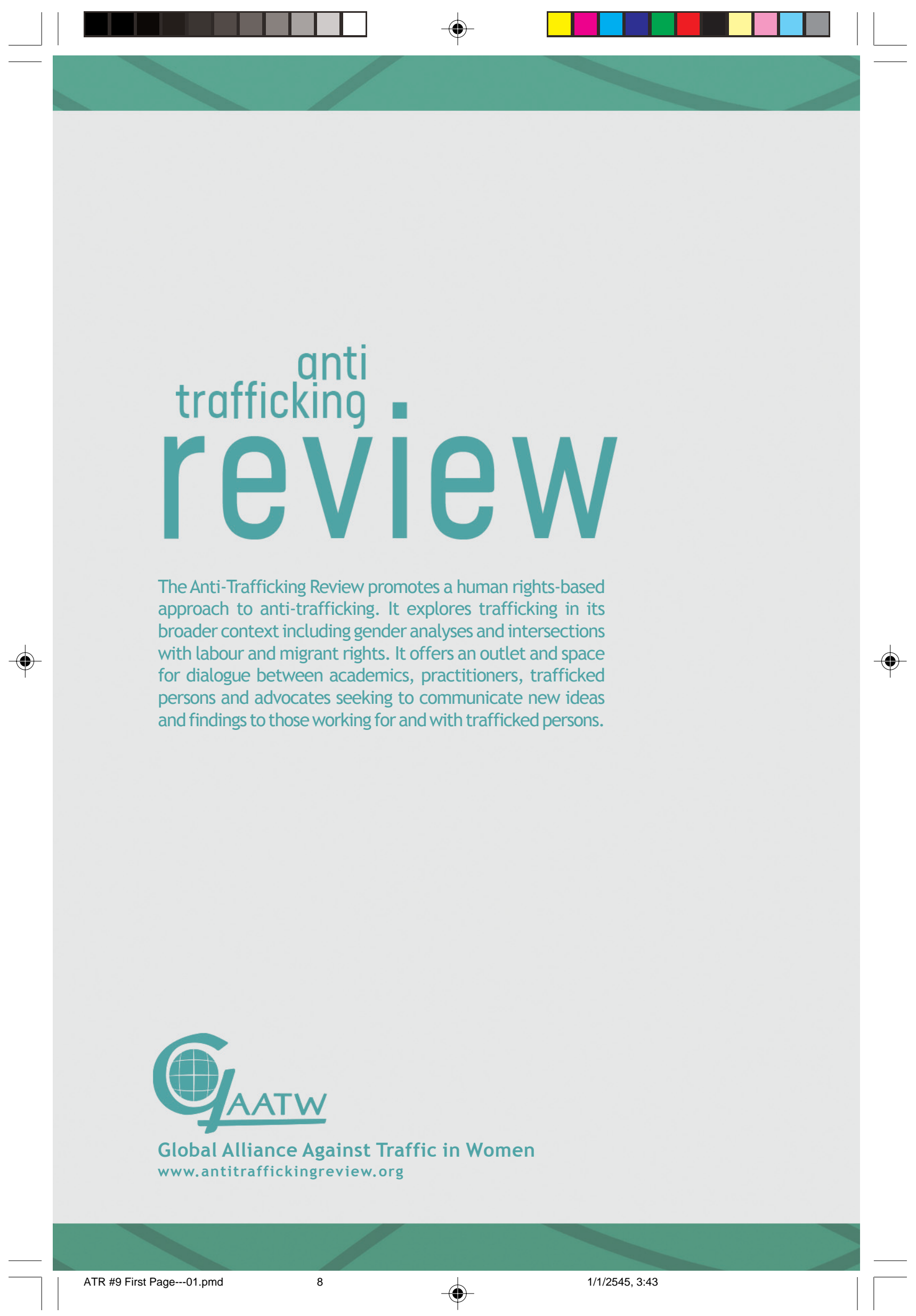

